EMANUELLA ROSYANE DUARTE MOURE

Alopecias Cicatriciais Primárias: Revisão de Achados Histopatológicos de 37 Pacientes do Departamento de Dermatologia do Hospital das Clinicas da Faculdade de Medicina da Universidade de São Paulo no período de 2000 a 2005

Dissertação apresentada à Faculdade de Medicina da Universidade de São Paulo para a obtenção do título de Mestre em Ciências

Programa de: Dermatologia

Orientador: Prof. Dr. Ricardo Romiti

São Paulo 
Dados Internacionais de Catalogação na Publicação (CIP)

Preparada pela Biblioteca da

Faculdade de Medicina da Universidade de São Paulo

Creprodução autorizada pelo autor

Moure, Emanuella Rosyane Duarte

Alopecias cicatriciais primárias : revisão dos achados histopatológicos de 37 pacientes do Departamento de Dermatologia do Hospital das Clínicas da Faculdade de Medicina da Universidade de São Paulo no período de 2000 a 2005 / Emanuella Rosyane Duarte Moure. -- São Paulo, 2010.

Dissertação(mestrado)--Faculdade de Medicina da Universidade de São Paulo. Programa de Dermatologia.

Orientador: Ricardo Romiti.

Descritores: 1.Alopecia 2.Cicatriz 3.Foliculite 4.Líquen plano 5.Lupus eritematoso discóide

USP/FM/DBD-442/10 
Dedico este trabalho...

A Deus, por ter me dado a possibilidade de ter os meios $e$ os instrumentos necessários para buscar o conhecimento. 
$\underline{\text { Agradecimentos }}$ 
À Profa. Dra Neusa Sakai Valente, minha amiga e professora, pelos grandes ensinamentos, pelo amor à Dermatologia, sobretudo à Dermatopatologia. Agradeço pelo apoio e pelo carinho dedicado a mim a ao nosso trabalho em todas as suas etapas.

Ao Prof. Dr. Ricardo Romiti por ter aceitado orientar este trabalho, acreditando que eu poderia realizá-lo. Por ter demonstrado que além do conhecimento, um grande mestre tem a capacidade de ouvir e ajudar seus colegas de trabalho.

À Profa. Dra. Mirian Nacagami Souto pelo exemplo de profissional, incentivando seus alunos a serem novos mestres e doutores, primando pela qualidade de seus trabalhos.

À Profa. Cecília Rivitti por ter plantado a semente deste trabalho e por ter ajudado a realizá-lo, mostrando-se sempre prestativa e atenciosa.

A todos os assistentes da Dermatologia, deixo meus sinceros agradecimentos, uma vez que com vocês adquiri a consciência da necessidade de ser um profissional qualificado, preparado e comprometido com a Dermatologia.

A minha mãe Odmarina Duarte, por ser meu grande exemplo de vida. Um ser humano que conseguiu abranger todas as qualidades que podem ser atribuídas à palavra mãe, dentre elas o amor incondicional. Sem ela nada seria possível, MUITÍSSIMO OBRIGADA!

Ao meu marido Emilio e a minha filha Julia, minha pequena-grande família, obrigada por vocês existirem e me fazerem tão feliz.

Ao meu pai João Alfredo Duarte, minha irmã Gabriella Duarte e ao meu futuro cunhado José Vidal Jr, pelo incentivo, pelo carinho e por terem me ensinado que família é para todas as horas. 
Aos meus amigos de residência por tornarem os dias mais fáceis, em especial as minhas companheiras de ambulatório, Aline Donati e Luciana Molina, por terem contribuído na realização deste trabalho.

A todos os funcionários da Dermatologia que permitem com que o serviço funcione da melhor forma possível, facilitando a lida com os pacientes, organizando consultas, cirurgias, parte técnica, manipulação de lâminas e parte burocrática.

Aos pacientes que nos ensinam e nos motivam diariamente.

A todas as pessoas que, de alguma forma, participaram desta conquista. 
Esta dissertação está de acordo com as seguintes normas, em vigor no momento desta publicação:

Referências: adaptado de International Committee of Medical Journals Editors (Vancouver)

Universidade de São Paulo. Faculdade de Medicina. Serviço de Biblioteca e Documentação. Guia de apresentação de dissertações, teses e monografias. Elaborado por Anneliese Carneiro da Cunha, Maria Julia de A. L. Freddi, Maria F. Crestana, Marinalva de Souza Aragão, Suely Campos Cardoso, Valéria Vilhena. 2a ed. São Paulo: Serviço de Biblioteca e Documentação; 2005.

Abreviaturas dos títulos dos periódicos de acordo com List of Journals Indexed in Index Medicus. 


\section{SUMÁRIO}

Lista de abreviaturas e símbolos

Lista de quadros

Lista de gráficos

Lista de figuras

Resumo

Summary

1 Introdução. 1

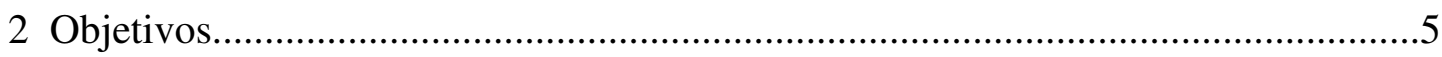

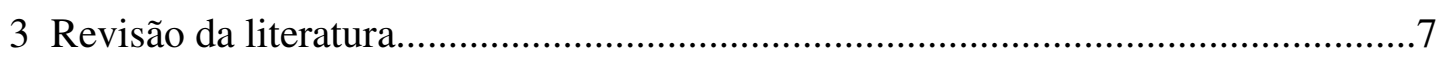

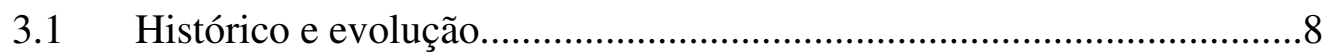

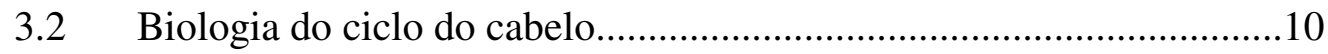

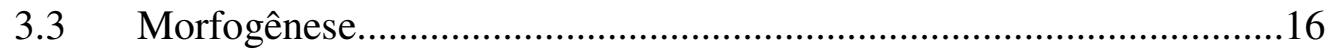

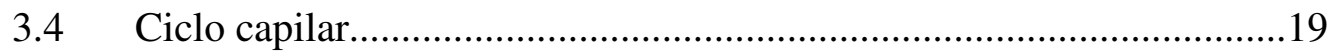

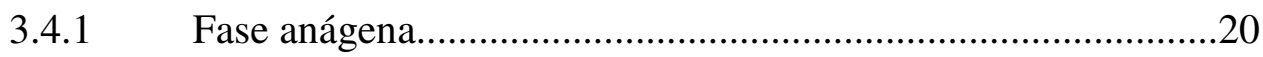

3.4.2 Fase catágena...............................................................21

3.4.3 Fase telógena.................................................................22

3.4.4 Fase exógena e Quenógena.................................................23

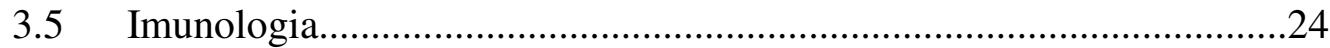

3.6 Etiologia e patogênese das alopecias cicatriciais................................26

3.6.1 Hipóteses para o desenvolvimento da inflamação na alopecia cicatricial.

3.6.1.1 Hipótese do desenvolvimento da alopecia cicatricial mediada

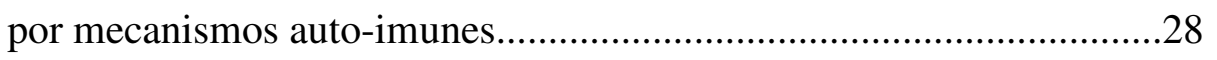

3.6.1.2Hipótese da quebra do privilégio

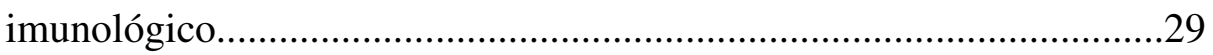

3.6.1.3 Hipótese do "o perigo versus o não perigo" das cicatrizes.........30

3.6.1.4 Hipótese da destruição das células-tronco do bulge ...................32

3.6.1.5 Hipótese da inibição da comunicação epitélio-mesenquimal do folículo piloso.

3.6.1.6 Hipótese da disfunção da glândula sebáceas baseada no modelo em ratos. 
3.6.1.7 Hipótese da mutação genética da queratina para o desenvolvimento da alopecia

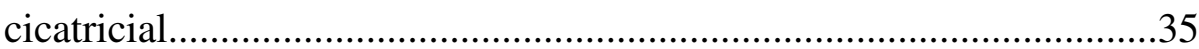

3.6.1.8 Hipotese do receptor ativado por proliferador de peroxissomo

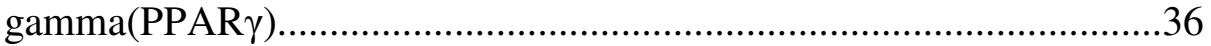

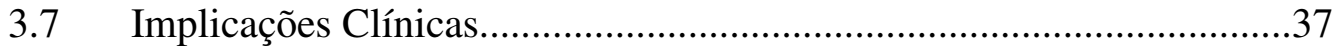

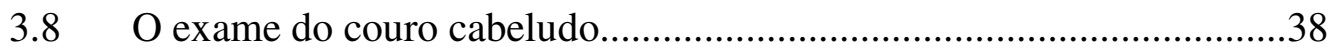

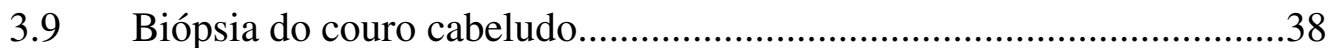

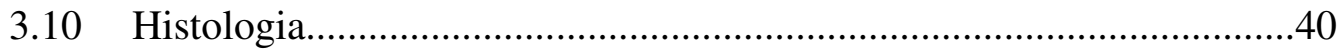

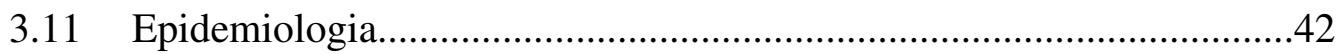

3.12 Alopecias cicatriciais primarias linfociticas........................................43

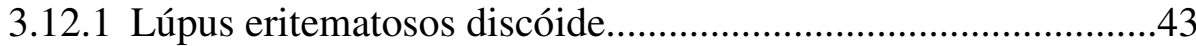

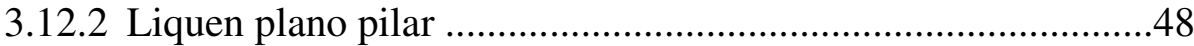

3.12.3 Pseudopelada clássica (de Brocq)..........................................53

3.12.4 Alopecia cicatricial central centrífuga......................................58

3.12.5 Alopecia Mucinosa................................................................61

3.12.6 Ceratose folicular espinulosa decalvante................................63

3.13 Alopecias cicatriciais primarias neutrofílicas......................................65

3.13.1 Foliculite decalvante...........................................................65

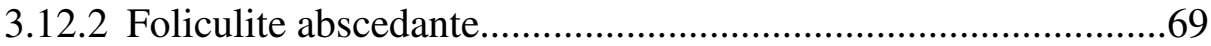

3.14 Alopecias cicatriciais primarias mistas................................................

3.14.1 Foliculite queloideana...........................................................71

3.14.2 Acne necrótica....................................................................74

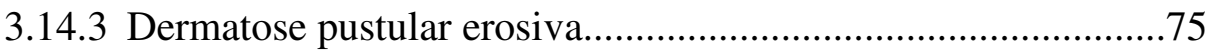

3.15 Alopecia cicatricial primária inespecífica.........................................75

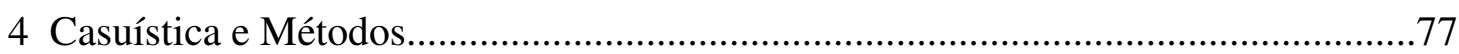

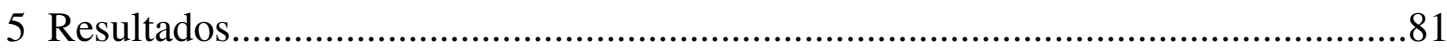

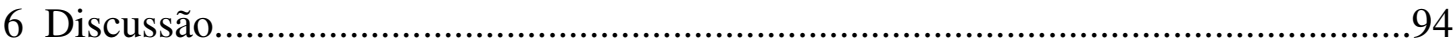

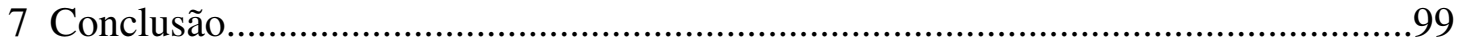

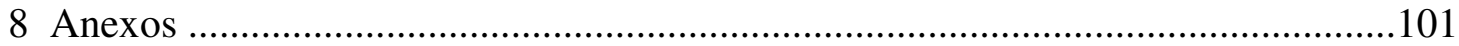

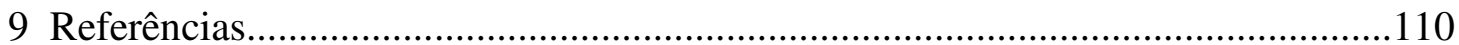


$\underline{\text { Listas }}$ 


\section{LISTA DE ABREVIATURAS}

$\mathrm{AFF}$

AM

$\mathrm{BE}$

BI

CARF

CD200

CD200R

CFED

et al.

FQ

FA

FD

HC-FMUSP Hospital de Clínicas da Universidade de São Paulo

HE

HLA

IFD

$\operatorname{Ig}$

LASER Light Amplification by Stimulated Emission of Radiation

LED

LPP

LE

MF

MHC

Nd: YAG

p. ex.

PAS

PB

PD

Alopecia frontal fibrosante

Alopecia mucinosa

Bainha radicular externa

Bainha radicular interna

Cicatricial Alopecia Research Foundation

Cluster de diferenciação 200

Receptor de CD200

Ceratose folicular espinulosa decalvante

e outros

Foliculite queloideana

Foliculite abscedante

Foliculite decalvante

Hematoxilina-eosina

Human leukocyte antigen (Antígenos Leucocitários Humanos)

Imunofluorescência direta

Imunoglobulina (classes: A,D,E,G,M)

Lupus eritematoso discóide

Líquen plano pilar

Lupus eritematoso

Micose fungoide

Major histocompatibility complex (complexo principal de histocompatibilidade)

North American Hair Research Society

Neodymium-doped yttrium aluminium garnet

Por exemplo

Periodic acid-Schiff

Pseudopelada de Brocq

Papila dérmica 
PPAR Peroxisome proliferator-activated receptors

S. aureus Staphylococcus aureus

SIF Sistema imune do foliculo

SIP Sistema imune da pele

UVB Ultravioleta B

\section{LISTA DE SÍMBOLOS}

$\begin{array}{ll}\mathrm{dl} & \text { decilitro } \\ \mathrm{kg} & \text { kilograma } \\ \mathrm{mg} & \text { miligrama } \\ \mathrm{mm} & \text { milimetros } \\ \mathrm{mm}^{2} & \text { milimetros quadrado } \\ \mathrm{nm} & \text { nanometro }\end{array}$




\section{LISTA DE QUADROS}

Quadro1. Classificação das alopecias cicatriciais primárias pela NAHRS, 1999; modificada em 2001

Quadro 2. Parâmetros histológicos utilizados na classificação das alopecias cicatriciais .79

Quadro 3. Comparação dos diagnósticos prévios e após a revisão, de acordo com os parâmetros histológicos pré-estabelecidos. .82 


\section{LISTA DE GRÁFICOS}

Gráfico 1. Distribuiçao das alopecias cicatriciais primárias de acordo com o

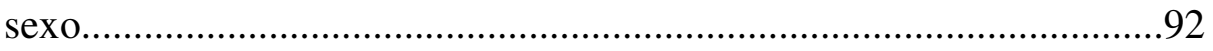

Gráfico 2. Distribuição das alopecias cicatriciais primárias de acordo com as

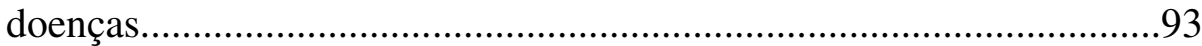




\section{LISTA DE FIGURAS}

Figura 1. Alopecias cicatriciais linfocíticas em fase tardia: Lúpus eritematoso: (a) alopecia cicatricial com esclerose dérmica do colágeno; (b) - hiperqueratose com rolhas córneas e atrofia epidérmica; (c) - mesmo em fase tardia há espessamento da membrana basal. HE (a,b,); PAS (c); Aumento original: x40 (a,); x100 (b, c, )...................86

Figura 2. Alopecias cicatriciais linfocíticas em fase tardia: Pseudopelada de Brocq: (a) - alopecia cicatricial; (b) - ausência de critérios para lúpus e líquen; (c) - manguito elástico perifolicular preservado $\mathrm{HE} \mathrm{(a,b);}$ Weigert (c) Aumento original: x40 (a); x100 (b); x200 (c) 87

Figura. 3 Alopecias cicatriciais linfocíticas em fase tardia: Líquen plano pilar: (a) - trato fibroso, infiltrado liquenóide perifolicular e ausência de outras alterações dermo-epidérmicas; (b) - numerosos corpos colóides dentro do trato fibroso; (c) - manguito elástico perifolicular parcialmente destruído. HE (a); PAS (b); Weigert (c) Aumento original: x40 (a); x100 (c); x400 (b) 88

Figura 4. Alopecias cicatriciais neutrofílicas em fase tardia: Foliculite decalvante; (a) - foliculite neutrofílica com intensa perifoliculite; (b) neutrófilos degenerados dentro do infundíbulo e infiltrado inflamatório perifolicular misto;(c) - alguns histiócitos multinucleados e plasmócitos; HE (a,b,c). Aumento original: 100x (a); 400x (b,c)........89

Figura 5. Alopecias cicatriciais neutrofílicas em fase tardia: Foliculite abscedante; (a) - fibrose cicatricial perifolicular e distante dos folículos, extensa e perifoliculite; (b) - infiltrado inflamatório plasmocitário; (c) - elastólise próxima e distante dos folículos. HE (a,b); Weigert (c). Aumento original: 100x (a,c); 400x (b). .90 
$\underline{\text { Resumo }}$ 
Moure ERD. Alopecias cicatriciais primárias: revisão dos achados histopatológicos de 37 pacientes do departamento de dermatologia do Hospital das Clínicas da Faculdade de Medicina da Universidade de São Paulo (HC-FMUSP) no período de 2000 a 2005 [dissertaçao]. São Paulo: Faculdade de Medicina, Universidade de São Paulo; 2010.

Introdução: As alopecias cicatriciais são subdivididas em primárias e secundárias. Nas alopecias cicatriciais primárias o folículo piloso é o alvo principal da destruição; diferentemente das secundárias onde a destruição folicular não é o evento patológico primário. Objetivo: Revisar os achados histológicos de pacientes com diagnóstico de alopecia cicatricial primária, em uma fase tardia e reclassificá-los em seus respectivos subtipos. Casuística e Métodos: Os espécimes de biópsia de pacientes com diagnóstico histológico prévio de alopecia cicatricial foram revisados e submetidos a colorações por hematoxilina e eosina (HE), ácido periódico-Schiff (PAS) e Weigert, a fim de reclassificá-los de acordo com os diferentes subtipos de alopecia. Foram utilizados para a revisão histológica critérios de infiltrado inflamatório acrescidos de coloração para fibra elástica. Resultados: Os 37 casos de alopecia cicatricial primária foram reclassificados em: lupus eritematoso discóide (16), líquen plano pilar (4), pseudopelada de Brocq (12), foliculite decalvante (3), foliculite abscedante/dessecante (1), e alopecia não-específica (1). Conclusão: Mesmo em uma fase tardia, pauci ou não inflamatória, o exame histológico, utilizando colorações de rotina, PAS e coloração para fibra elástica, permitiu o diagnóstico mais acurado das alopecias cicatriciais primárias.

Descritores: Alopecia, Cicatriz, Foliculite, Líquen Plano, Lupus Eritematoso Discóide 
$\underline{\text { Summary }}$ 
Moure ERD. Primary cicatricial alopecias: a review of histopathologic findings in 37 patients from a clinical University Hospital in Sao Paulo, Brazil [dissertation]. São Paulo: “Faculdade de Medicina, Universidade de São Paulo"; 2010.

BACKGROUND: Scarring alopecias are classified into primary and secondary according to the initial site of inflammation. In primary scarring alopecias, the hair follicle is the main target of destruction. The term secondary cicatricial alopecia implies that follicular destruction is not the primary pathologic event. AIMS: To review the histopathologic diagnoses of cases of cicatricial alopecia in order to classify them according to the North American Hair Research Society. PATIENTS AND METHODS: Patients with biopsy specimens diagnosed as cicatricial alopecia seen from 2000 to 2005 at the Dermatologic Department of Hospital das Clínicas, São Paulo University Medical School had hematoxylin and eosin, Periodic Acid-Schiff (PAS) and Weigert stained slides reevaluated and sub-typed into different primary cicatricial alopecias. RESULTS: Thirty-seven cases of primary cicatricial alopecias were reclassified as: discoid lupus erythematosus (16), lichen planus pilaris (4), pseudopelade of Brocq (12), folliculitis decalvans (3), dissecting folliculitis (1), and non-specific scarring alopecia (1). CONCLUSIONS: Even in late, pauci or noninflammatory phases, an approach with systematic evaluation of a constellation of criteria in routine hematoxylin and eosin stain, PAS and Weigert stain permitted an accurate diagnosis of cicatricial alopecias.

Descriptors: Alopecia, Scar, Folliculitis, Lichen Planus, Discoid Lupus Erythematosus. 
1 Introducão 
Alopecia é uma palavra latina, cuja origem pode ser atribuída à palavra grega "alopekia", derivada de "alopek", que significa "raposa". A palavra "alopekia" literalmente traduzida é um termo para sarna em raposas e como tal, quer dizer em humanos uma perda de cabelo total ou parcial em determinada área do corpo (IrbyMassie, 2007).

As alopecias manifestam-se por afetar determinadas fases do ciclo de crescimento do cabelo de forma reversível ou irreversível e podem ser classificadas em cicatriciais e não-cicatriciais. A característica definidora de todas as alopecias cicatriciais é a destruição folicular, que ocorre frequentemente associada à fibrose dérmica (Sellheyer e Bergfeld, 2006).

São algumas as classificações para as alopecias cicatriciais, como as que se baseiam na sua origem (congênita ou adquirida). A forma mais usada na literatura é a que prefere subdividir as alopecias de acordo com o padrão da destruição folicular em alopecias cicatriciais primárias e secundárias. (Ristrepo et al., 2005).

Existe ainda um grupo de alopecias cicatriciais que decorrem da persistência de anormalidades na dinâmica folicular, estas formas de alopecia caracterizadas inicialmente como não cicatriciais, após vários anos ou décadas de contínua atividade da doença, acabam por levar a um dano permanente do folículo. Neste grupo temos as formas crônicas de alopecia androgenética, alopecia areata e alopecia de tração (Sperling, 2001).

Nas alopecias cicatriciais primárias o folículo piloso é o alvo principal da destruição, microscopicamente evidenciada pela preferência ao epitélio folicular e/ou de sua adventícia, poupando a derme reticular. Este grupo inclui as seguintes entidades clínicas: Lupus Eritematoso Discóide (LED), Líquen Plano Pilar (LPP), 
Pseudopelada de Brocq (PB), Foliculite Decalvante (FD) e Foliculite Abscedante/Dissecante (FA) (Templeton e Solomon, 1994).

O termo alopecia cicatricial secundária significa que a destruição folicular não é primária; os eventos ocorrem, por exemplo, na derme reticular, epiderme ou subcutâneo afetando e eventualmente erradicando o folículo. Incluem-se nestas, as alopecias cicatriciais decorrentes de fatores exógenos, como queimaduras; ou endógenos, como doenças infiltrativas ou inflamatórias (sarcoidose, pênfigo vulgar, tinha do cabelo, esclerodermia, neoplasias entre outros) (Templeton e Solomon, 1994).

As alopecias cicatriciais primárias são um complexo grupo de transtornos com pouco conhecimento sobre sua causa, patogênese e opções de tratamento. A razão para esta falta de conhecimento decorre da maioria dessas condições serem encontradas com menor frequiência na clínica do que outros tipos perda de cabelo. Muito do que sabemos tem sido reportado a partir da experiência clínica de pequenos grupos de tricologistas e poucos relatos de casos (Ross, 2007).

Dentro do universo das alopecias cicatriciais primárias, há uma variedade de entidades nosológicas com diferentes etiologias e características clínicas distintas. Os achados específicos de cada doença são de forma geral, mais evidentes nos seus estágios iniciais, conforme a alopecia progride as características clínicas e histológicas das diferentes doenças se sobrepõem, tornando a caracterização delas quase impossível. Este problema se torna ainda mais complexo pelo fato da maioria dos pacientes com alopecia cicatricial serem assintomáticos e procurarem ajuda médica em uma fase mais avançada da doença (Ristrepo et al., 2005).

Nas fases iniciais das alopecias cicatriciais, além da ausência total ou parcial das 
estruturas foliculares, podemos observar ao exame clínico, achados que facilitam na distinção da doença, como eritema e queratose folicular, induração ou atrofia da pele, alterações pigmentares e pústulas, que acrescidos da presença ou ausência de achados cutâneos, os quais analisados em conjunto quando feita uma boa anamnese, favorecem a obtenção de um diagnóstico mais acurado. Embora possamos afirmar que seja difícil determinar mesmo com esses achados se a alopecia é de natureza cicatricial (Otberg et al.,2008).

Estudos ao longo do tempo têm sido feitos com o intuito de diferenciar as alopecias cicatriciais primárias do ponto de vista microscópico. Atualmente muitos autores têm preferido uma classificação proposta em 2001, pela North American Hair Research Society (NAHRS), baseada no padrão do infiltrado inflamatório e no tipo de célula inflamatória predominante (Olsen et al.,2003).

Histologicamente, uma fase inicial ainda permite ao patologista avaliar a localização e o tipo de infiltrado inflamatório envolvido, a presença ou ausência de fibrose, as alterações de interface no infundíbulo folicular, a morfologia dos folículos e o estágio do ciclo capilar envolvido (Templeton e Solomon, 1994).

Já em uma fase tardia, onde achados clínicos evidentes não estão presentes, o diagnóstico histopatológico também se torna difícil. A avaliação do tipo e da localização do infiltrado inflamatório predominante nem sempre é possível, tendo-se na amostra somente a ausência obvia dos folículos capilares (alopecia no "estágio final"). Nestes casos, para que o diagnostico seja possível, devemos lançar mão de critérios adicionais, como o estudo do manguito elástico perifolicular, que possibilitam a classificação das alopecias cicatriciais primárias mesmo em uma fase adiantada. 
2 Objetivos 
Os objetivos deste trabalho são:

2.1 Revisar os achados histológicos de pacientes com diagnóstico de alopecia cicatricial primária em fase tardia, pauci inflamatória, diagnosticados no Hospital das Clínicas da Faculdade de Medicina da Universidade de São Paulo, no período de 2000 a 2005, a fim de reclassificá-los segundo o tipo de infiltrado inflamatório predominante.

2.2 Realizar colorações específicas como o ácido periódico-Schiff (PAS) e coloração para fibra elástica pela resorcina-fucsina de Weigert, a fim de verificar a relevância destas na obtenção de diagnósticos mais acurados na análise histológica de alopecias cicatriciais primárias, mesmo em uma fase adiantada. 
3 Revisão da Literatura 


\subsection{Histórico e evolução:}

As origens do pelo datam de um réptil ancestral desconhecido, que viveu há mais de 300 milhões de anos, na era Paleozóica. Os pelos provavelmente se desenvolveram como parte da unidade mecanorreceptora desses animais, que foram os primeiros ancestrais a deixarem o ambiente aquático para o meio externo (Pereira, 2005; Owen 2008).

Desde então, o pelo, que proporciona isolamento e proteção, é visto como uma das principais inovações evolucionárias, que levou ao êxito dos mamíferos, através dos fenômenos de camuflagem e termorregulação (Owen, 2008).

Nossos ancestrais pré-sapiens viveram principalmente em regiões tropicais e subtropicais e, quando a população humana na qual eles se desenvolveram, deixou a floresta tropical e passou para ambientes mais abertos adotando a vida de caçador, houve uma dependência do pelo e do suor para a dissipação térmica e perda de calor pelo corpo. Para melhorar o potencial termoregulador da pele, notavelmente entre os "Hominoidea", a evolução dos mamíferos geralmente foi acompanhada de uma aparente "tendência à nudez", caracterizada pela redução gradual dos pelos corporais em favor das glândulas sudoríparas. Com o tempo, pressões seletivas agiram em níveis genéticos, determinando perda desta função de isolamento térmico pelos pelos do corpo dos seres humanos, que passaram a ter apenas uma função mais decorativa e menos protetora (Pereira, 2005; Stenn e Paus, 2001).

Os pêlos assim como as unhas representam apêndices inovadores na replicação epitelial, uma maneira antiga e de sucesso empregada na evolução dos vertebrados, onde uma população circunscrita de células da camada basal da epiderme se espessa 
sobre uma faixa definida de mesênquima e são submetidas a um programa de diferenciação altamente especializado e geneticamente definido. Tornando a natureza cíclica do folículo um dos mais importantes sistemas para se estudar as interações mesênquima-epitélio (Wu et al, 2004).

Os pelos também estão relacionados a características sexuais, Darwin (1871) citado por Pereira (2005) relata que a seleção sexual da mulher a favor de homens cabeludos, levou gradualmente a diferenças evolutivas entre o masculino e o feminino.

Em algumas culturas, o aspecto dos cabelos assinala diferenças sociais ou profissionais; já em outras, atende a exigências religiosas ou até mesmo a posicionamentos políticos. De fato, foi sugerido que a perda dos cabelos pode ter sido o impulso para o interesse de Hipócrates pelos caminhos da medicina, assim como podemos observar que grandes líderes mundiais como presidentes, na sua grande maioria não são calvos (Pereira, 2009).

O homem além de não gostar de ver sua própria imagem sem cabelos, também não consegue criar um deus sem cabelos. Avaliando todas as religiões e mitologias, percebe-se que não existe um deus sem cabelos. Buda, cinco séculos antes de Cristo, ainda jovem, cortou seus cabelos em sua expressão máxima de renúncia aos bens materiais (Pereira, 2009).

Inúmeras lendas, fábulas e escrituras, envolvem em suas estórias a presença marcante dos cabelos. Assim ocorreu com Sansão que revelou à Dalila que sua força residia em seus longos cabelos e com Rapunzel, que ao ser presa em uma torre, jogava suas longas tranças para que seu guardião subisse até ela (Pereira, 2009). 
Na sociedade contemporânea, a aparência de nossos cabelos está muitas vezes ligada à percepção da saúde e sentimento de autoconfiança, compondo a moldura do rosto, os cabelos sinalizam formas de encarar a vida e, muitas vezes, importantes mudanças do comportamento pessoal. Contribuindo para uma imagem clássica ou radical. Os cabelos são repletos de significados, constituem-se na característica mais marcante e variável dos seres humanos, tornando-se ingredientes fundamentais da identidade pessoal. Devido à sua importância visual, os pêlos têm funções psicossociais e sexuais inter e entre as espécies. Isto são reflexos da grande atenção, energia e pesquisa investida pelos mamíferos em todos os tipos e culturas, no preparo, manipulação e conservação dos cabelos, bem como no alto grau de frustração, tristeza e disfunção social causada pela perda ou desfiguração deste apêndice epidérmico - especialmente entre os homens (Sinclair et al, 1999; Hadshilew et al, 2004).

\subsection{Biologia do ciclo do cabelo:}

O aparato pilossebáceo que é formado pelo folículo piloso, glândula sebácea e músculo piloeretor, é uma estrutura cilíndrica bem organizada, multicelular, que produz outra estrutura complexa, o pelo (Paus et al., 2008).

Calcula-se que a pele humana contenha aproximadamente 05 milhões de folículos pilosos, com cerca de 100.000 folículos presentes no couro cabeludo (Sinclair, 1999), não sendo formados, em circunstâncias normais, folículos adicionais após o nascimento. No corpo humano, somente as regiões palmar e plantar, lábio 
inferior e pênis não contêm unidades pilossebáceas (Fisher e Hyatt,1987; Ahmed e Jaspan , 1994).

Em um corte longitudinal, podem se distinguir diferentes porções do folículo piloso, que são denominadas: infundíbulo (desde o poro até a desembocadura da glândula sebácea), istmo (entre a glândula e a inserção do músculo eretor do pelo) e segmento inferior, situado abaixo do músculo eretor (Sampaio e Rivitti, 2000).

Considera-se acrotríquio como a porção intra-epidérmica do folículo, haste capilar como a porção livre do pelo situada acima do nível da epiderme e raiz do pelo como sua porção intra-dérmica (Fisher e Hyatt,1987).

No segmento inferior do folículo está situado o bulbo que é a parte mais espessa e profunda. O bulbo folicular anágeno contém uma das mais rápidas populações de células proliferativas do organismo dos mamíferos, os chamados ceratinócitos da matriz germinativa.

Entre as células da matriz germinativa existem corpos celulares de melanócitos que emitem prolongamentos longos contendo melanina e que são fagocitados pelas células da matriz germinativa para que ocorra a pigmentação da haste, estes melanócitos são distintos daqueles da epiderme, possuindo longos dendritos e menor relação melanócito-ceratinócito (1:1 - 1:4) que na unidade melânica epidérmica (1:25 - 1:40) (Tobin e Paus, 2001). De maneira geral, a pigmentação do cabelo durante a fase anágena é promovida pela transferência de dois tipos de pigmentos produzidos na unidade pigmentar do folículo piloso: se o pigmento dominante for a eumelanina a cor será preta, e se o pigmento principal for a feomelanina a cor será amarela ou vermelha (Jankovic SM e Jankovic SV,1998). 
A matriz folicular recobre uma papila de tecido conjuntivo, denominada papila dérmica (PD) (Ham WH, 1967; Sampaio e Rivitti, 2000) onde se encontram vasos e nervos finos. A PD é composta de fibroblastos especializados localizados na base do folículo; acredita-se que esses fibroblastos produzam sinais que induzam a divisão das células da matriz. Estas células moveriam-se para a porção superior formando a haste e a bainha interna (Kealey et al., 1997).

Pelo menos oito cilindros concêntricos constituindo os compartimentos epiteliais do folículo piloso, podem ser observados: a bainha externa (BE), a bainha de companhia, a bainha interna (BI) que por sua vez é composta pela camada de Henle (BI), camada de Huxley (BI) e cutícula (BI), assim como a haste composta pela cutícula, córtex e medula (Taylor et al., 2000).

Conforme o pêlo emerge da região da matriz, é incorporado pela bainha radicular interna (BI), a qual orienta a fibra capilar central utilizando-se da camada íntima da bainha radicular externa (BE): a bainha de companhia (que provavelmente representa um compartimento de células independentes com um papel fundamental na fixação do cabelo). Desta forma a presença de estruturas guias e planos de clivagem conduzem o crescimento direcionado do folículo piloso, cuja arquitetura é designada cuidadosamente para que o mesmo alcance a superfície cutânea sem ser introduzido na derme, onde poderia iniciar uma reação necrotizante tipo corpo estranho (Paus et al., 2008).

A bainha radicular interna (BI) é formada por três camadas separadas, chamadas cutícula, camada de Henle, e camada de Huxley. As escamas da cutícula, da BI, se intercomunicam com a cutícula do pêlo, ocorrendo, assim, um ancoramento firme. A 
bainha de Huxley forma o volume da BI e pode participar do molde geométrico do formato da haste capilar (Stenn e Paus, 2001), embora este seja determinado principalmente pelo bulbo capilar (Thibaut et al.,2005), particularmente pelo grau de simetria/assimetria axial da matriz. Foi demonstrado que no cabelo crespo um dos lados da cutícula do cabelo se desenvolve primeiro, dando a este bulbo o aspecto de taco de golfe; já no liso, o desenvolvimento é igual e reto (Bouillon, 1988). A bainha radicular interna sofre decomposição (descamação) logo abaixo do local de inserção do ducto da glândula sebácea.

A bainha radicular externa forma o cilindro externo do folículo piloso e comunica a epiderme adjacente com o bulbo piloso inserido na hipoderme. A BE, contígua com a epiderme, separa a BI e seus componentes, da derme. Em contraste com a BI e o pêlo, derivados de células da matriz germinativa, a BE é derivada de células basais epidérmicas e tem como funções: ser um reservatório de célulastronco, servir como rota de passagem de nutrientes e oxigênio para o folículo, servir como armazenamento de energia (glicogênio) e ser uma estrutura de apoio e orientação para a BI e a haste (Paus et al, 2007).

Células provenientes da parte central da região da matriz logo acima da papila dérmica dão origem à haste pilosa que de dentro para fora consiste de três partes: medula, córtex e cutícula. A medula é formada por um eixo central de células fracamente queratinizadas e mal interconectadas, compõe-se de fileiras de células poliédricas contendo grânulos de eleidina (substancia oleosa afim com a queratina) e frequentemente espaços aéreos, e está ausente no lanugo e no velus humano (Ham, 1967; Fischer et al,1987; Junqueira e Carneiro,1999). 
O principal componente estrutural da haste capilar é o córtex, suas células são alongadas e unidas para formar fibras fusiformes e achatadas contendo grânulos de pigmento nos pêlos escuros e ar nos brancos, ele é composto por um grupo de tricócitos completamente ceratinizados, compactados, interligados em forma de fuso e unidos por um material proteináceo que confere à haste excepcional resistência ao estresse mecânico além de alta elasticidade. O córtex é coberto pelas células da cutícula, composta de uma camada simples de escamas achatadas que se sobrepõem da profundidade para a superfície, ricas em proteínas sulfurosas e organizadas como telhas no telhado. A cutícula é responsável principalmente por manter a haste no folículo e protegê-la da ação do tempo. O dano cuticular causa alterações na haste capilar como fraturas, fendas e quebra total do fio (Paus et al., 2008).

As glândulas sebáceas são estruturas lobulares e saculares que se abrem no terço superior do folículo através de seus canais excretores, e produzem o sebo cuja função é lubrificar os pêlos e a pele. Cada folículo é provido de uma a seis glândulas sebáceas (Hollinshead, 1980).

O ângulo na qual se encontra a haste pilosa em relaçao a pele muda pela ação das fibras de um músculo liso, chamado músculo eretor do pelo. Este músculo está sob controle adrenérgico, e situações de estresse repentino, ansiedade ou raiva, levam a contrações involuntárias diminuindo obliqüidade do folículo em relação à pele, tornando-o reto (Paus et al., 2008).

$\mathrm{Na}$ região de inserção do músculo eretor do pelo, no istmo, existe um espessamento na camada basal da bainha radicular externa e que contém melanócitos e células pluripotenciais em atividade, conhecido como protuberância (ou bulge), considerado o principal sítio de células progenitoras, importantes para regeneração e 
para o ciclo folicular. As células da matriz são formadas a partir do bulge e o seu crescimento e diferenciação sofrem influências de substâncias produzidas na papila dérmica (Taylor et al.,2000; Cotsareis et al.,1999) que induzem pelos anágenos, dando origem as chamadas células amplificadas transitórias, que são queratinócitos, mitoticamente ativos, da matriz, que se diferenciam na haste do cabelo (Sellheyer e Bergfeld, 2006). Por outro lado, a atividade secretória da papila é controlada por mediadores das células da camada espinhosa da bainha radicular externa e por hormônios.

O sistema de inervação do folículo piloso é o responsável pelas propriedades do folículo, de alta sensibilidade tátil, que registra sensações muito delicadas através da movimentação das hastes capilares. Além disso, o plexo neural folicular também apresenta importante função de tropismo e regulação devido à liberação de neurotransmissores, neuropeptídeos e neurotrofinas (Paus et al., 2008).

A vasculatura capilar está localizada sobre o plexo vascular dérmico e subcutâneo e é formada por arteríolas, capilares e vênulas com numerosas anastomoses. Este sistema de perfusão alcança todo o folículo e garante que todas as regiões do mesmo tenham acesso a nutrientes, oxigênio, moléculas biorregulatórias sistêmicas e hormônios permitindo também que produtos deletérios produzidos por vias metabólicas e de pigmentação do bulbo na fase anágena sejam carreados para excreção e desintoxicação do folículo Paus et al., 2008).

Os folículos humanos tendem a se organizar em aglomerados de três ou mais folículos denominados "unidades foliculares", (apresentando folículos terminais e/ou velus, arranjados sobre uma área de aproximadamente $1 \mathrm{~mm}^{2}$ ). Em uma biópsia do couro cabeludo, feita por punch de $4 \mathrm{~mm}$, seccionada horizontalmente, é possível 
encontrar em torno de 12-14 unidades foliculares (Whiting,2003). Este alto nível de organização estrutural e o fato de que o transplante de unidades foliculares inteiras ofereça vantagens na cirurgia de restauração do cabelo (Unger, 2005), sugere que as unidades foliculares estão ligadas funcionalmente às unidades pilossebáceas e aos seus músculos eretores do pêlo como um conjunto de mini-órgãos.

\subsection{Morfogênese}

A morfogênese do folículo piloso inicia-se na nona semana de vida embrionária, a partir de um pequeno broto epitelial da epiderme, bem acima de uma condensação mesenquimal e, rapidamente progride para a formação de unidades pilosas multicilíndricas e maduras, estreitamente relacionadas com as glândulas sebáceas Paus et al., 2008).

Muitas células de origem embrionária distintas cooperam para a formação do folículo piloso e de sua haste pigmentada, entre estas células, os ceratinócitos e os fibroblastos altamente especializados que apresentam propriedades indutoras e morfogenéticas; os melanócitos (Peters et al.,2002), as células de Langerhans e as células T intraepiteliais (Paus et al.,1998). Outros grupos celulares incluem fibras nervosas, vasos sanguíneos assim como mastócitos e macrófagos que surgem somente após o desenvolvimento inicial do folículo e que juntamente com as células de Langerhans e as células T intraepiteliais (Paus et al., 1998) formam parte do sistema imune do folículo piloso.

Um campo morfogenético criado na epiderme resultante provavelmente de elementos sinalizadores intercomunicantes que funcionam como estimuladores ou 
inibidores da indução folicular, levam à formação de um aglomerado de ceratinócitos que cresce para baixo em direção a derme como uma sólida coluna de células proliferativas, esculpidas por apoptose (morte programada de células) (SchmidtUllrich e Paus, 2005).

A $\beta$-catenina faz parte de um complexo grupo de proteínas que regulam o crescimento celular e a adesão entre as células. Sinalizações realizadas pela família das integrinas e pela $\beta$-catenina (produzida pela papila dérmica) parecem ser os principais envolvidos na regulação deste crescimento para baixo dos ceratinócitos na via de diferenciação folicular. A sinalização feita pela $\beta$-catenina é essencial para as células tronco, uma vez que os ceratinócitos na ausência de $\beta$-catenina destinam-se a formação epidérmica, enquanto que a grande expressão de $\beta$-catenina leva a formação de folículos pilosos em anágeno (Fuchs e Raghavan, 2002).

A morfogênese folicular é composta de três fases: indução, organogênese e citodiferenciação. Sob condições fisiológicas, a indução folicular pode ser negativamente controlada (Botchkarev et al., 1999; Nakamura et al., 2002), isto significa, que na pele normal, o balanço é feito no sentido da supressão do desenvolvimento folicular, assim, a indução folicular, não ocorre até que inibidores do aglomerado sejam suficientemente neutralizados, o que poderia ser visto como uma proteção contra malignidades, em particular daquelas com origem nas célulastronco foliculares (Oshima et al.,2001; Taylor et al., 2000). Na região palmo-plantar, esta desinibição nunca ocorre espontaneamente, o que explica a completa ausência de folículos pilosos e glândulas sebáceas nestas regiões.

Uma vez que o aglomerado tenha sido formado, sinais epidérmicos provavelmente são necessários para induzir o desenvolvimento do 'centro de 
comando mesenquimal' na papila dérmica folicular (PD), iniciando a fase da organogênese. Durante esta fase, a PD começa a expressar proteoglicana sulfato de condroitina além de regular a atividade da fosfatase alcalina como indicador do aumento de seu poder de indução (Paus et al., 2007).

A inervação alvo-específica do folículo em desenvolvimento e a angiogênese devida a fatores de crescimento endoteliais tornam-se detectáveis também na fase de organogênese. Nesta fase, sinais epiteliais são necessários para guiar melanoblastos ao epitélio folicular, cujo estagio final acontece, quando melanócitos começam a formar a unidade pigmentar do folículo piloso.

O começo da terceira fase, a citodiferenciação do folículo, ocorre em torno da $11^{\circ}$ semana de desenvolvimento embrionária e coincide com o início da geração da melanina. A diferenciação de ceratinócitoss individuais em sebócitos, no epitélio superior do folículo, ou em células que se transformam em precursores da glândula apócrina, inicia-se também em torno desta fase. Durante este período mais tardio de desenvolvimento do folículo, o epitélio folicular é povoado por células de Langerhans e células $\mathrm{T}$ migratórias além de um número crescente de mastócitos e macrófagos que se acumulam no mesênquima perifolicular (Paus et al.,1998).

Um evento crítico da citodiferenciação é a formação da BI, cujas células serão as primeiras do folículo a diferenciar-se até a fase terminal. Assim, lentamente, formase um tubo rígido, onde no centro estão localizados os tricócitos que irão produzir a haste do cabelo compactada. A formação da BI é uma etapa crucial na morfogênese do folículo piloso, uma vez que anuncia que o folículo está se preparando para a sua função chave: a fabricação das hastes pilosas (Paus et al., 2008). 
Sob circunstâncias fisiológicas, a formação dos folículos pilosos ocorre somente durante o desenvolvimento da pele, isto é, nos seres humanos até antes do nascimento.

Durante o desenvolvimento humano da pele, cada folículo piloso intra-útero gera um primeiro tipo de haste com pouco pigmento e fina, chamada lanugo, "um cabelo teste", que cai em torno de 7-8 meses de gestação e um segundo, mais curto e menos pigmentado, que cai 3-4 meses após o nascimento. Estas primeiras duas ondas de formação de haste capilar são razoavelmente sincronizadas, após isso, os folículos pilosos humanos convertem-se para um padrão de ciclo em mosaico, isto é, cada folículo segue seu próprio ritmo de ciclo (Paus e Cotsarelis, 1999).

Após a conclusão de seu desenvolvimento, cada folículo piloso anágeno está ativamente produzindo hastes pilosas, e deverá experimentar um curso completo de transformações, que começa com a regressão apoptose-dirigida (catágeno), seguida por um período de quiescência relativa (telógeno) (Paus et al., 2008).

Em corte transversal para o estudo da microanatomia do couro cabeludo, cada folículo, é arbitrariamente dividido em velus, intermediário e terminal. Os velus contem pelos cuja hastes pilosas possuem diâmetro menor que $0,03 \mathrm{~mm}$ ou cujo diâmetro seja igual ou menor a espessura da BI. Os folículos intermediários contem pelos cujas hastes pilosas possuem diâmetro que varia de $0,03 \mathrm{~mm}$ a $0,06 \mathrm{~mm}$ e os folículos terminais contem pelos cujas hastes pilosas possuem diâmetro maior que 0,06mm ou cujo diâmetro seja maior que a espessura da BI (Headginton e Astle, 1987).

\subsection{Ciclo Capilar}


A potencialidade para distinguir os estágios individuais de transformação do folículo, que ocorrem durante o ciclo do pelo, através de critérios morfológicos definidos e marcadores moleculares é de grande interesse para o especialista.

Experimentos com transplante estabeleceram, que o sistema molecular oscilatório e autônomo que dita o ciclo folicular, reside no e/ou em torno do próprio folículo. Este relógio cíclico do folículo continua a operar mesmo depois que um folículo é transplantado em sítio anatômico cutâneo diferente, bem como na cultura orgânica do folículo. Entretanto, sua natureza exata, ainda é obscura (Paus et al., 2008).

O ciclo capilar é tradicionalmente reconhecido por três fases: crescimento (anágeno), regressão (catágeno) e repouso (telógeno). Segue-se uma sequência rítmica repetitiva de mudanças características na morfologia do folículo que obedecem a uma organização sequencial geneticamente codificada (Robbins, 2002).

\subsubsection{Fase Anágena}

Tradicionalmente, o folículo anágeno é dividido em: (1) segmento inferior, constituído principalmente pelo bulbo, também chamado de "porção cíclica" do folículo, uma vez que se submete a mudanças morfológicas dramáticas durante cada ciclo; e (2) seguimento superior que consiste na região do bulge, istmo e infundíbulo, chamado habitualmente de "porção permanente" do folículo, onde nenhum remodelamento dramático é evidenciado durante o ciclo do cabelo (Paus et al., 2008). 
O desenvolvimento anágeno, morfologicamente, recapitula em parte os estágios intermediários e tardios do desenvolvimento do folículo piloso. Muito dos fatores moleculares importantes, que dirigem a indução e a morfogênese do folículo, são reutilizados durante o desenvolvimento do pelo anágeno.

$\mathrm{Na}$ fase anágena, o cabelo está crescendo ativamente, e materiais são depositados em sua haste pelas células da papila folicular. A duração desta fase é determinada geneticamente e varia dependendo do sítio anatômico estudado. No couro cabeludo, tem duração de 2 a 6 anos (Bouillon e Wilkinson, 2005) com taxa de crescimento de aproximadamente 0,03 a $0,045 \mathrm{~mm}$ por dia, sendo a taxa de crescimento mais acelerada nas mulheres (Trüeb, 2003). Aproximadamente 85-90\% de todos os cabelos estão nesta fase de crescimento.

\subsubsection{Fase Catágena}

A fase catágena é muito controlada, a apoptose e a diferenciação terminal fazem a involução rápida do folículo, enquanto a fábrica real da haste capilar, o bulbo, é desmontado quase que completamente (Abraham et al, 2009). A apoptose ocorre também na região do bulge e na glândula sebácea durante a fase catágena, isso enfatiza o fato de que nenhum compartimento do folículo piloso pode ser considerado verdadeiramente 'permanente' (Ito et al., 2004).

A papila dérmica folicular não sofre apoptose, ela se condensa e move-se para cima. Há também um declínio do número de núcleos dos seus fibroblastos, provavelmente pela migração desses, da papila, para a bainha de tecido conjuntivo proximal (Abraham et al., 2009). 
Os sinais mais precoces do término da fase anágena e da indução da catágena são a retração dos dendritos melanócíticos do folículo finalizando a melanogênese. A maioria desses melanócitos também sofre apoptose. Os melanócitos destruídos no folículo são repostos durante a próxima fase anágena, a partir do reservatório de células-tronco melanocíticas no bulge (Abraham et al., 2009). A canície, então, seria em grande parte uma manutenção insuficiente no folículo piloso de células-tronco melanocíticas no seu nicho (Osawa,2005).

Durante a fase catágena, a papila folicular encolhe e a BRE pela "força apoptótica' transforma-se em saco epitelial, cabelo em "clava". Este tem a característica de apresentar a ponta como uma escova e a extremidade proximal despigmentada, uma vez que é gerada somente após o final da melanogênese e da transferência dos melanossomas. Menos de $1 \%$ dos cabelos está nesta fase de involução, que pode durar entre 2 e 3 semanas (Wickett, 1987).

\subsubsection{Fase Telógena}

No fim do processo de involução, o folículo entra no seu "estágio de repouso", chamado telógeno, nesta fase a atividade proliferativa e bioquímica do folículo alcança seu nível mais baixo. Entretanto, a fase telógena pode apresentar uma importância regulatória muito maior para o folículo do uma "fase de repouso", isto implica que esta fase serve como uma pausa para a fase anágena (Abraham et al., 2009). 
O cabelo fica em fase telógena por 03 meses, e aproximadamente 10-15\% dos fios de cabelo estão em repouso, refletindo uma queda de 100-120 fios por dia normalmente (Stenn e Paus, 2001).

\subsubsection{Fase Exógena e Quenógena. ${ }^{1}$}

Existem duas outras fases descritas na literatura, a exógena e a quenógena. $\mathrm{Na}$ primeira, foi demonstrado que a exclusão da haste capilar é ativa, altamente controlada, o que difere da fase telogênica a qual é normalmente quiescente. Já a fase quenógena é um fenômeno novo no ciclo capilar, que representa o folículo vazio entre o fim da fase telógena e a nova fase anágena. Pode ser achado em pessoas normais, mas parece ser mais comum em indivíduos com alopecia androgenética (Abraham et al., 2009).

O resultado final destas interações sinalizadoras em torno de um folículo individual, especialmente o balanço local entre inibidores e estimuladores no bulge, no germe folicular e na papila dérmica, determina, como e quando, o folículo piloso se submeterá a suas transformações cíclicas características (Paus et al., 2008).

Além disso, assim como ocorre durante o desenvolvimento do folículo piloso (Schmidt-Ullrich e Paus, 2005), diferentes tipos de folículos, em locais diversos da pele, apresentam controles cíclicos completamente distintos - como o famoso "efeito paradoxo dos androgênios" na barba diverso daquele na região fronto-temporal do couro cabeludo (Randall et al., 2001).

\footnotetext{
${ }^{1}$ Fases não consagradas na literatura
} 
Sob circunstâncias fisiológicas, eventos de remodelamento na inervação e vascularização do folículo e as mudanças resultantes, como por exemplo, na liberação de estímulos neurotróficos e na perfusão do folículo, servem para facilitar e sintonizar as transformações foliculares, sendo componentes prováveis e integrantes de controle no ciclo capilar (Paus et al.,1997).

\subsection{Imunologia.}

O canal folicular é uma das principais portas de entrada para organismos infecciosos, contudo, em indivíduos imunocompetente, sinais de infecção são excepcionalmente raros, se considerarmos o vasto número de tais portas de entrada. Isto se deve a um sistema de defesa anti-infecção eficiente na BE distal, constituído por uma densa trama de células de Langerhans e células dendríticas, em forma de anel, no epitélio folicular distal, e a um grande número de mastócitos e macrófagos perifoliculares. Como parte deste sistema, o epitélio folicular humano também expressa uma variedade de $\beta$-defensinas (Chronnell et al.,2001), que compõem parte do elaborado e evolucionário sistema imune não-específico do folículo piloso.

O canal folicular abriga uma microflora residente rica e normalmente nãopatogênica, (p.ex. Staphylococcus aureus, Prapionibacterium acnes, Demodex folliculorum, Malassezia) e serve como um reservatório para um número de patógenos tais como o papilomavirus. Além de seu papel na degradação do sebo e no estabelecimento do $\mathrm{pH}$ da pele, esta microflora residente, serve para 'educar' o sistema imune em desenvolvimento, para que ele diferencie os agentes infecciosos e os antígenos prejudiciais daqueles que devem ser tolerados (Sterling, 2005). 
Embora o sistema imune do folículo (SIF) seja componente integral do sistema imune da pele (SIP), ele difere do último pelo menos em três aspectos: (1) a BE distal dos folículos humanos abriga um MHC classe II relativamente imaturo e deficiente, com uma população funcionalmente "danificada" de células de Langerhans que serve supostamente como um reservatório intermediário entre a medula óssea e a epiderme; (2) as células de Langerhans e os receptores $\gamma / \delta$ ou $\alpha / \beta$ de linfócitos intra-epitérmicos não são distribuídos homogeneamente em todas as camadas do epitélio folicular, reduzindo em número conforme se afastam da superfície epidérmica e (3) ao contrário de todos os outros compartimentos da pele, a matriz do folículo, estabelece uma área de relativo "privilégio imune" (que são locais isolados do sistema imunológico nos quais os antígenos contidos nesses compartimentos são protegidos dos elementos do ataque do sistema imune) durante a fase anágena (Paus e Ito, 2003).

Enquanto mastócitos e macrófagos parecerem influenciar pouco, na função da epiderme normal, estes elementos celulares do SIP estão integrados no controle do crescimento do cabelo, com propriedades significativas e moduladoras, mais notavelmente nos ratos, mas possivelmente também no couro cabeludo humano. O SIP é recrutado mesmo sob circunstâncias fisiológicas para eliminar folículos mal funcionantes em um processo 'micro-imunecirúrgico' de 'deleção programada do órgão’ onde um infiltrado maciço perifolicular de macrófagos ativados e algumas células $\mathrm{T}$ atacam a região do bulge folicular, a qual apresenta capacidade de regeneração devida seu reservatório chave de células-tronco. Em circunstâncias patológicas, esta condição de deleção ocorre de maneira exagerada, resultando em 
uma alopecia cicatricial como a que ocorre, por exemplo, no líquen plano pilar. (Eichmüller et al.,1998).

Duas potentes classes de imunossupressores - glicocorticóides e ligantes da imunofilinas (p.ex. ciclosporina) - estão entre os mais poderosos agentes moduladores do crescimento do cabelo, embora os exatos mecanismos subjacentes envolvidos permaneçam desconhecidos (Paus et al.,1994).

Citocinas, fatores de crescimento, hormônios, neuropeptídeos e neurotransmissores, moduladores do ciclo do folículo, também apresentam propriedades imunes a serem melhor estudadas (Paus et al.,2008).

\subsection{Etiologia e Patogênese das Alopecias Cicatriciais}

Familiarizar-se com a anatomia básica e a fisiologia do folículo capilar fornece uma melhor visão sobre a origem das alopecias. A distinção entre as várias formas de alopecia cicatricial tem sido feitas de acordo com características clínicas e patológicas, entre outros fenômenos observados.

Em um esforço para aumentar a compreensão sobre as alopecias cicatriciais primárias, um workshop patrocinado pela Sociedade Norte-Americana de Pesquisadores de Cabelo ("NARHS”) foi realizado em 2001 e resultou no desenvolvimento de um sistema de classificação cujo objetivo foi padronizar a comunicação entre pesquisadores e clínicos sobre o assunto. Em um consenso, cada entidade foi classificada de acordo com a célula inflamatória predominante envolvida (linfócito/neutrófilo e misto) (Olsen et al., 2003) presente em amostras de biópsia do couro cabeludo de lesões clinicamente ativas (Quadro 1). 
Quadro 1. Classificação das alopecias cicatriciais primárias pela "NAHRS" 1999, modificada em 2001

\section{Linfocíticas \\ Lupus eritematoso discóide \\ Líquen plano pilar \\ Pseudopelada de Brocq \\ Alopecia frontal fibrosante \\ Sindrome de Graham-Little \\ Queratose folicular espinulosa decalvante \\ Neutrofílicas \\ Foliculite decalvante \\ Foliculite dissecante \\ Mistas \\ Acne queilodiana \\ Acne necrótica \\ Dermatose pustular erosiva \\ Alopecia cicatricial primária não especícifica.}

Desde então, uma série de artigos a partir de pesquisas clínicas e básicas têm sido publicados sobre novos aspectos dessas doenças, e novas teorias têm avançado sobre a patogênese das alopecias cicatriciais primárias (Stenn et al., 2001). Em 2005, pesquisadores foram convocados pela primeira vez pelos institutos de saúde nacionais para reverem essas condições e recomendarem diretrizes para pesquisas futuras (Ross et al., 2005). Este colóquio foi liderado pela Fundaçao de Pesquisa de Alopecias Cicatriciais (“CARF”).

\subsubsection{Hipóteses para o desenvolvimento da inflamação na alopecia cicatricial.}

Em muitos casos de alopecia cicatricial, o exame de biópsia de rotina revela que os folículos capilares afetados são cercados por intenso infiltrado inflamatório com 
foco primário na porção superior e permanente do aparelho pilossebáceo. Células de Langehans, concentradas no epitélio infundibular, sebáceo e no bulge, presumivelmente iniciam uma primeira linha imune em resposta a ameaças endógenas e exógenas promovendo a viabilidade folicular. (Ross et al., 2005).

Não surpreendentemente, isso levou a uma série de hipóteses, ainda que limitadas, envolvendo a destruição da unidade folicular mediada por células inflamatórias. Embora não haja correlação em humanos, modelos animais de alopecia cicatricial primária estendem esse entendimento, demonstrando uma variedade de mecanismos patogênicos, para que esta condição se desenvolva.

\subsubsection{Hipótese do desenvolvimento da alopecia cicatricial mediada por mecanismos auto-imunes.}

Uma das hipóteses para o desenvolvimento das alopecias cicatriciais linfocíticas é de que elas fossem de natureza auto-imune. Essencialmente o termo autoimunidade, engloba apresentação de auto-antígenos ao sistema imune adaptativo e ativação de linfócitos com produção de auto-anticorpos, sempre que esses antígenos forem identificados. Uma entidade muito complexa e com muitas variações nos mecanismos de desenvolvimento e apresentação (McElwee, 2008).

Uma doença autoimune decorre da quebra na tolerância imunológica, ou seja, uma ruptura do poder discriminatório das células imunologicamente competentes em distinguir antígenos originados do próprio corpo daqueles não próprios. No entanto, o que existe de conhecimento até o momento sobre as alopecias cicatriciais, não nos 
permite saber se linfócitos presentes na periferia são auto-reativos contra epítopos de antígenos do folículo piloso, ou seja, contra antígenos endógenos. Apesar de o LED ter como uma de suas características a presença de imunocomplexos no epitélio folicular, demonstrado à imunofluorescência direta (IFD), a especificidade dos anticorpos produzidos, ainda não foi profundamente investigada (Trachsler e Trueb, 2005).

A prova que confirmaria de alguma maneira que as alopecias cicatriciais estariam envolvidas com doenças auto-imunes, seria a identificação de anticorpos específicos contra o folículo piloso, no sangue de pacientes afetados, o que não foi possível até o momento (Tobin, 2003; McElwee, 1996).

A hipótese apresentada de um mecanismo de doença auto-imune, apesar da falta de maiores evidências, pressupõe que o sistema imunológico poderia estar predisposto ao desenvolvimento de uma alopecia cicatricial. Se este fosse o caso, seria igualmente possível antecipar uma associação da doença, através de Antigénios de Leucócitos Humanos (HLA) em pacientes afetados.

\subsubsection{Hipótese da quebra do privilégio imunológico.}

Sabe-se que a porção inferior cíclica do folículo é imunoprivilegiada. Hipoteticamente cogita-se também que fatores de proteção secretados nesta área, estejam presentes mesmo que em menor quantidae, na região permanente do folículo (Moresi e Horn,1997).

Na região permanente do folículo piloso, reside uma população de células de Langerhans, a qual presume-se estar envolvida na vigilância do canal folicular para 
uma potencial invasão de patógenos. No entanto, é possível que nesta região, essas células possam estar envolvidas na imunorregulação e na tolerância imunológica a antígenos do folículo piloso (Moresi e Horn,1997).

De acordo com esta hipótese (McElwee, 2008):

Em respostas a estímulos, "defeituosas" células de Langerhans residentes, e células dendríticas vizinhas, poderiam ser inadequadamente ativadas. A migração de células apresentadoras de antígenos ativadas para os linfonodos e a apresentação de antígenos que ocorreria devido a essa quebra parcial ou total do privilegio imune da região permanente, poderiam iniciar uma resposta imunológica voltada à porção permanente da unidade pilosebácea, resultando em uma alopecia cicatricial.

Desta forma, é possível que as alopecias inflamatórias sejam o resultado de uma falha no privilégio imune do folículo e uma variedade de estímulos, têm sido sugeridos, para essa falha e indução do infiltrado inflamatório no desenvolvimento das alopecias cicatriciais. Exemplos de possíveis estímulos antigênicos incluem a luz ultravioleta (no couro cabeludo) no LED, medicamentos no LPP e infecção por $S$. aureus na foliculite decalvante.

\subsubsection{Hipotese do "o perigo versus o não perigo" das cicatrizes.}

A falha na distinção do "eu" versus o "não-eu" é uma maneira popular de explicar a natureza e o desenvolvimento da auto-imunidade. No entanto, mais recentemente hipóteses alternativas para explicar a auto-imunidade foram desenvolvidas e uma delas é a hipótese do "perigo versus o não perigo das cicatrizes", originalmente sugerida por Matzinger et al. (2002). Segundo estes 
autores, apenas os tecidos ativariam o sistema imunológico, exibindo sinais de "perigo" que o mesmo pudesse reconhecer.

O cluster de diferenciação (ou de designação), por vezes abreviado como CD, é um protocolo utilizado para a identificação e investigação de moléculas da superfície celular presentes nas células brancas do sangue e podem agir de várias maneiras, muitas vezes atuando como receptores ou ligantes (moléculas que ativam um receptor).

O CD200 (cluster de diferenciação 200) é uma proteína humana codificada pelo gene CD200. A proteína codificada por este gene é um tipo de glicoproteína de membrana, que pertence à superfamília das imunoglobulinas. Estudos em ratos sugerem que este gene pode regular a atividade das células mielóides e fornecer um sinal inibitório para a linhagem dos macrófagos em tecidos diversos (McElwee, 2008).

Partindo deste princípio, Rosenblum et al. (2006) sugeriram um mecanismo para o desenvolvimento da alopecia cicatricial, à luz de suas pesquisas sobre a expressão do CD200 nos folículos pilosos. Eles propuseram que uma expressão de CD200 pelos queratinócitos foliculares, principalmente na bainha radicular externa, é um sinal de "não perigo".

A interação de CD200 com o receptor de CD200 (CD200R) das células de Langerhans e dendríticas atuariam como um sinal inibitório do tipo "não perigo" para alguma resposta inflamatória, mantendo os leucócitos em um estado inativo. No entanto, se a expressão de CD200, nos queratinócitos foliculares, fosse perdida, células CD200R positivas elevariam seu estado de ativação. 
Segundo esta hipótese, traumas na pele ("perigo das cicatrizes") iniciariam uma ativação completa de CD200R, com consequente e significativa inflamação foliculocêntrica que poderiam ser suficientes para quebrar a tolerância de linfócitos e levar ao recrutamento e ativação de células $\mathrm{T}$ auto-reativas, especificas contra os folículos pilosos, causando mais destruição folicular no meio inflamatório.

Rosenblaum et al. (2006) certamente tem evidências de seu modelo em ratos para demonstrar que este seria um mecanismo potencial para o desenvolvimento das alopecias cicatriciais. Além disso, este talvez seja o modelo atual que define em parte, os passos necessários para o desenvolvimento da doença. No entanto, ainda deve ser pesquisado se em humanos, a expressão de CD200 desempenha realmente um papel chave para o desenvolvimento da alopecia cicatricial.

\subsubsection{Hipótese da destruição das células-tronco do bulge .}

Atualmente, a distinção entre alopecias inflamatórias cicatriciais e não cicatriciais, como a alopecia areata, normalmente concentra-se na localização do infiltrado inflamatório. Na alopecia areata, a localização do infiltrado é peri e intrafollicular em torno do bulbo e na região cíclica da porção inferior do folículo pilossebáceo (Whiting, 2003).

Supõe-se que a cicatrização e a destruição permanente dos folículos pilosos afetados não acontecem na alopecia areata, porque o infiltrado inflamatório não parece estar direcionado para a região permanente do bulge, onde estão localizadas as células-tronco do folículo piloso. Em contrapartida, nas alopecias cicatriciais inflamatórias, o infiltrado inflamatório é predominantemente voltado para a região 
permanente não cíclica da unidade pilossebácea que tem estreita associação geográfica com as células-tronco do bulge (Sperling e Cowper, 2006).

Potencialmente a destruição das células-tronco do bulge, levaria a destruição permanente do folículo piloso (Headington, 1996). A primeira vista esta hipótese faria muito sentido, o rompimento de partes permanentes da unidade pilossebácea a partir da qual a fase anágena é derivada, poderia resultar em uma falha na sobrevivência do folículo piloso para gerar futuras fases de crescimento.

$\mathrm{Na}$ alopecia areata, uma falta do infiltrado inflamatório visando à região permanente da unidade pilossebácea deixa as células-tronco intactas e potencialmente capazes de regenerar futuramente a fase anágena transitória das regiões em crescimento (Sperling e Cowper, 2006).

Por outro lado, a dissecção e transplante da região do bulbo folicular lhe permitem sobreviver apesar da aparente separação do bulge, ou seja, o isolamento, a cultura e a implantação de células mesenquimais do folículo piloso, para induzir a formação de folículo, sugerem que o mesênquima é capaz de formar folículos pilosos com qualquer fonte de queratinócitos não necessitando de células especificamente do bulge.

Sendo assim, estas observações, não apoiariam a hipótese da destruição das células-tronco exclusivamente, para o desenvolvimento das alopecias cicatriciais (McElwee, 2008), pois falharia em resolver requisitos fundamentais para o funcionamento da unidade pilossebácea, como a comunicaçao dos componentes epiteliais com o componente de produção mesenquimal da papila dérmica. A natureza dessa comunicação é pouco entendida, mas é claro que ambos os 
componentes devem sobreviver e permanecer em associação estreita, para o desenvolvimento do cabelo e do ciclo capilar.

\subsubsection{Hipótese da inibição da comunicação epitélio-mesenquimal do foliculo piloso.}

A observação através da patologia do processo inflamatório que ocorre nas alopecias cicatriciais, como no LPP, revelam que o estágio final da doença apresentase com uma falta completa tanto da porção cíclica quanto da permanente do folículo piloso. Isso inclui a perda de ambos os componentes, epiteliais e mesenquimais, necessários para o crescimento. É possível então, que a ação principal do infiltrado inflamatório, na alopecia cicatricial, seja inibir bioquimicamente e / ou fisicamente a comunicação entre a papila dérmica derivada do mesênquima, das células epiteliais.

Uma perda da comunicação entre o epitélio do folículo piloso e o mesênquima poderia resultar na perda da coerência de organização entre ambos, necessária para a manutenção continuada do tamanho, forma e atividade de suas estruturas essenciais. A hipótese da inibição da comunicação epitelio-mesenquimal, não é incompatível com a hipótese da destruição das células tronco do bulge, mas sugere uma diferença no foco. A destruição do bulge por si só, não seria necessária, ao contrário, a interferência na comunicação entre as células-tronco epiteliais e o mesênquima do folículo piloso já seria suficiente para garantir a desintegração do folículo (McElwee, 2008).

Isto abre a possibilidade de células inflamatórias terem como alvo, uma série de tipos de células da parte permanente do folículo piloso tais como a bainha dérmica, a bainha externa radicular e glândulas sebáceas, que poderiam igualmente ser 
potenciais alvos de ataque e não apenas as células-tronco do bulge. Qualquer que seja o alvo de interesse para as células inflamatórias, se a natureza da segmentação fosse suficiente para perturbar a comunicação epitélio-mesenquimal, a unidade pilossebácea poderia ser interrompida de forma irreversível.

Levando isso em conta, a questão principal para a compreensão da patogênese da alopecia cicatricial é definir como a comunicação no folículo piloso é interrompida antes que se inicie o ataque das células inflamatórias, pois na verdade, a atividade inflamatória poderia ser inteiramente secundária a uma falha da comunicação epitélio-mesenquimal do folículo piloso (McElwee, 2008).

\subsubsection{Hipótese da disfunção da glândula sebáceas baseada no modelo em ratos.}

O rato Asebia é o modelo mais extensivamente estudado nas alopecias cicatriciais primárias, ele apresenta uma única mutação autossômica que resulta na produção ou função deficiente da coenzima estearil. Esta enzima expressa na glândula sebácea, afeta o teor dos ácidos graxos do sebo. O fenótipo destes ratos apresenta-se com desenvolvimento rudimentar das glândulas sebáceas e com uma inflamação significativa associada à destruição do folículo piloso (McElwee, 2008).

A interpretação do tempo de curso dos estudos sugere que a mudança na composição do sebo resultaria em uma falha anormal da descamação da bainha radicular interna, evitando o egresso do cabelo durante a fase catágena, desta forma o bulbo capilar seria perfurado pelo eixo do cabelo e o processo inflamatório seria induzido (Sundberg, 2000). 
O rato Asebia e modelos com fenótipos semelhantes sugerem que a alopecia cicatricial poderia se desenvolver a partir de um defeito intrínseco da função da glândula sebácea. Por sua vez, isto sugere que a inflamação na alopecia cicatricial poderia mais uma vez, com na hipótese anterior, ser um fenômeno secundário e não um defeito primário da unidade pilossebácea. (McElwee, 2008).

\subsubsection{Hipótese da mutação genética da queratina para o desenvolvimento da alopecia cicatricial.}

Nesta hipótese, doenças da queratina, geneticamente determinadas, poderiam induzir a inflamação nas alopecias cicatriciais devido um defeito primário da queratina. Um exemplo clínico é a Ceratose Folicular Espinulosa Decalvante (CFED), uma doença rara ligada ao $\mathrm{X}$ e que está associada com um infiltrado linfocitico nos folículos pilosos (van Osch, 1992).

Padrões semelhantes de alopecia cicatricial foram descritos em ratos transgênicos expressando genes mutantes de queratina. (Sundberg e King, 1996).

\subsubsection{Hipotese do Peroxisome proliferator-activated receptor (PPAR- $\gamma$ ).}

Recentemente, tem sido sugerido um papel potencial para o PPAR- $\gamma$ no desenvolvimento da alopecia cicatricial do LPP.

No campo da biologia molecular, os PPARs (Peroxisome proliferator-activated receptor) são um grupo de proteínas receptoras nucleares que funcionam como fatores de transcrição e que regulam a expressão dos genes. Os PPARs desempenham 
um papel essencial na regulação da diferenciação celular, desenvolvimento, metabolismo (carboidratos, lipídios, proteínas) e carcinogênese de organismos superiores (Schmuth et al., 2008).

No folículo, o PPAR- $\gamma$ é um receptor nuclear que é reconhecido como tendo um papel central na homeostase de lipídios e, em especial, na diferenciação e na maturação dos sebócitos. Além disso, o PPAR- $\gamma$ também é necessário para a manutenção das células-tronco epiteliais do bulge (Schmuth et al., 2008).

A supressão do PPAR- $\gamma$ na área do bulge, com base em um modelo em ratos, gera uma patologia de pele que se assemelha ao LPP em vários aspectos. Karnik et al (2007), sugerem que a desregulação do PPAR- $\gamma$ não só explica a atrofia das glândulas sebáceas vista precocemente nessa condição, como pode ser a chave para o início do infiltrado leucocitário foliculocêntrico, resultando no desenvolvimento de uma alopecia cicatricial, associada com significativa inflamação focal e deposição de lipídeos na derme.

De forma resumida, várias hipóteses foram apresentadas para tentar explicar os mecanismos de patogênese das alopecias cicatriciais. Cada hipótese não necessariamente exclui a outra e é possível que diferentes hipóteses acabem por ser, respectivamente, ligadas a diferentes apresentações das alopecias cicatriciais.

\subsection{Implicações Clínicas:}

Na maioria dos casos de alopecia cicatricial primária, o exame histopatológico revela um processo inflamatório que afeta a porção superior do folículo onde os componentes vitais estão alojados, resultante de uma estimulação antigênica das 
células Langehans que estão posicionadas nesta porção permanente unidade pilossebácea. Como foi citado anteriormente, exemplos de possíveis estímulos antigênicos incluem a luz ultravioleta naqueles com LED; certos medicamentos no LPP e o Staphilococcus aureus na foliculite decalvante. Qualquer que seja o evento inicial, a obliteração ou perturbação funcional permanente dos elementos críticos necessários para reconstituição folicular que ocorrem, resulta em alopecia permanente. Implicitamente, a capacidade de restauração das glândulas sebáceas e da epiderme também é perdida, o que poderia explicar a observação comum de atrofia ou destruição epidérmica e da glândula sebácea vista em alguns tipos de alopecia cicatricial primária. Em contraste, quando a inflamação está limitada à porção inferior do folículo, como ocorre nas alopecias não cicatriciais como a alopecia areata, esses elementos críticos dentro do folículo se preservam e o potencial de recrescimento do cabelo permanece intacto. (Ross et al., 2005).

\subsection{O exame do couro cabeludo:}

O exame de todo o couro cabeludo, usando uma lente de aumento de três vezes ou mais, para ver o couro cabeludo cheio de cicatrizes, e as superfícies adjacentes, é recomendado. Iluminação lateral e comparação com as áreas de cabelo normal do couro cabeludo são necessárias para apreciar sinais sutis de uma condição patológica.

A localização dos sinais e sintomas, quando presentes, muitas vezes pode direcionar o clínico para as áreas de doença ativa. Estigmas foliculares e interfoliculares tais como queratose, eritema, alterações pigmentares e atrofia; o padrão de alopecia (desigual, reticulada, central, etc), provas cutâneas características 
extracranianas e exames complementares, quando necessários, devem ser analisados. Uma biópsia do couro cabeludo para confirmação da impressão diagnóstica é na maioria das vezes sugerida (Otberg et al., 2008; Ross et al., 2005).

\subsection{Biópsia do couro cabeludo.}

A biópsia do couro cabeludo é de grande valor para a avaliação das alopecias. $\mathrm{O}$ local escolhido para biópsia do couro cabeludo é fundamental e determinado pelas informações clínicas, devendo ser contemplado o estado da doença representativa, principalmente se na fase ativa, com características morfológicas primárias e exame de tração positivo (quando possível) (Ross et al., 2005). Idealmente duas biópsias deveriam ser obtidas de diferentes áreas: uma da área afetada e uma segunda, retirada de uma área periférica a lesão, supostamente "saudável” (Templeton e Solomon, 1994).

$\mathrm{Na}$ ausência de inflamação visível, como pode ocorrer em entidades, como a pseudopelada de Brocq, a biópsia de um local adjacente a area de alopecia, com uma relativa escassez de óstios foliculares pode ser suficiente (Templeton e Solomon, 1994).

Um espécime de biópsia de quatro milímetros verticalmente seccionado por punch incluindo o tecido celular subcutâneo é adequado para avaliar alopecias associadas a mudanças na interface, infiltrados liquenoides e patologias subcutâneas. Em secções verticais (longitudinais) convencionais, no entanto, apenas parte de pequeno número de unidades foliculares são observadas, devido ao crescimento em 
ângulo oblíquo dos folículos pilosos, que quando cortados tangencialmente, não podem ser visualizados na sua totalidade (Ross et al., 2005).

Muitos autores preferem biseccionar a biópsia transversalmente, Headington (1996) demonstrou que o melhor local fica 1mm acima da junção dermo-subcutânea, já Templeton e Solomon (1994) têm indicado 1,5mm ou 1-1,2mm abaixo da junção dermo-epidérmica, contudo, independentemente de qualquer nível de biópsia transversal escolhida, o objetivo final é alcançar a área ístmica. O istmo é o local onde as unidades foliculares residentes oferecem a maior quantidade de achados diagnósticos, permitino inclusive a realização da contagem exata da relação destas unidades, achado importante para alopecias não cicatriciais. $\mathrm{O}$ seccionamento transversal permite a visualização da maioria dos folículos e em vários níveis, mas para isso, é necessária uma equipe bem treinada de laboratório que possibilite uma boa técnica de incorporação do espécime. As desvantagens do corte transversal incluem inexperiência com o processamento da amostra e interpretação, bem como perda de detalhes da relação patológica, da junção dermo-epidérmica, derme papilar e panículo (Stefanato, 2010).

As secções verticais, por sua vez, encontram sua importância por abrangerem toda a espessura da pele na secção, uma característica notadamente útil na avaliação das alopecias cicatriciais.

Por esta razão, nas alopecias cicatriciais, de acordo com o consenso norte americano realizado em 2001 (Olsen et al., 2003), o procedimento ideal para o estudo das alopecias é a realização de duas biópsias profundas (até o subcutâneo), com punch de $4 \mathrm{~mm}$, onde um espécime seria submetido a seccionamento transvessal para realização das colorações necessárias (hematoxilina-eosina (HE), mucina, ácido 
periódico-Schiff (PAS), fibra elástica) e o outro submetido a corte vertical em dois pedaços iguais, um para colorações de rotina e o outro para o exame da imunofluorescência direta (IFD), que tem sua importância particularmente nas alopecias cicatriciais linfocíticas (Otberg et al., 2008).

\subsection{Histologia}

Geralmente, as alopecias afetam determinadas fases do ciclo do cabelo, os mais vulneráveis são os cabelos anágenos, que estão na fase de crescimento ativo, caracterizando-se por intensa síntese de DNA e melanogênese. Do total de 100.000 pêlos do couro cabeludo, cerca de $85 \%$ estão em fase anágena, que dura entre 2 e 7 anos.

Ao exame histológico o folículo anágeno apresenta suas bainhas radiculares interna e externa, completamente desenvolvidas, sem sinais de apoptose. Folículos pilosos anágenos no estágio tardio estendem-se para o tecido subcutâneo e revelam aspecto característico de "aparência de bola e luva" com a matriz contornando a papila (Bergfeld,1989). A mudança do folículo anágeno metabolicamente muito ativo para a fase telógena quase "inerte" induzida por estímulos internos ou externos, impedem maiores danos ao folículo piloso e, muitas vezes permitem a recuperação e a retomada do crescimento do cabelo uma vez que cessem os eventos estimulantes (Sellheyer e Bergfeld, 2006).

Variando em torno de 2 a 3 semanas, a catágena representa a fase mais curta de todo o ciclo do crescimento do cabelo e é morfologicamente caracterizada por uma bainha radicular fibrosa ondulada e células apoptóticas dispersas, especialmente na 
bainha radicular externa, localizada na porção média e inferior do folículo. Comparado com o folículo piloso da fase anágena, o catágeno está localizado mais superficialmente na pele, comumente na junção da derme com o subcutâneo. Apenas 1-2\% dos fios de cabelo são catágenos e, portanto, em uma secção com punch de 4mm, de uma biopsia de couro cabeludo normal, os folículos pilosos catágenos são raramente encontrados (Sperling, 1991).

Cerca de $15 \%$ dos pêlos do couro cabeludo estão na fase telógena, onde a síntese de DNA cessou e a melanogênese está inativa. Esta fase dura cerca de três meses, no final da qual o fio de cabelo cai ao mesmo tempo em que, inicia-se um novo ciclo de crescimento folicular, com a indução de novos pêlos anágenos. Os folículos telógenos estão localizados na derme média ou superior e consistem apenas da parte permanente do folículo piloso (infundíbulo e istmo) com a haste do cabelo em forma de "clava", rodeada por um saco epitelial.

No telógeno, um trato angiofibrótico (caracterizado como células epiteliais em meio a fibras colágenas espessadas e concêntricas, com aumento da vascularização, na derme profunda e na hipoderme) chamado de "trato fibroso", estende-se desde o istmo até o tecido subcutâneo e indica a posição anterior dos cabelos anágenos. Durante todo o ciclo de crescimento do cabelo, a papila folicular trilha para cima, junto com o segmento inferior de regressão do folículo piloso (Sellheyer e Bergfeld, 2006).

\subsection{Epidemiologia:}


A epidemiologia das alopecias cicatriciais primárias na população geral ainda é desconhecida. A partir de dois grandes estudos, do tipo série de casos, conduzidos em universidades, com pacientes provenientes de ambulatórios de tricologia foi possível a obtenção de nossos dados.

No primeiro estudo feito por Whiting, em Dallas, Texas (2001), as alopecias cicatriciais foram diagnosticadas em $7,3 \% \quad(n=427)$ de todos os pacientes acompanhados em um período de dez anos (1989-1999). A maioria dos afetados eram mulheres adultas, com proporção de 2,6: 01 em relação aos homens. A média de idade foi de 36 anos para homens e 43 anos para as mulheres e de todos os pacientes com alopecia cicatricial que foram biopsiados, as alopecias cicatriciais primárias representaram um predomínio de 4:1 em relação às secundárias (Ross et al., 2005).

No outro estudo, feito por Tan e colaboradores (2004), na Universidade de British Columbia, em Vancouver no Canadá, 3,2\% $(\mathrm{n}=112)$ dos pacientes atendidos por doenças de cabelo, tinham diagnóstico de alopecia cicatricial primária, estes revelaram ao exame histológico um predomínio do infiltrado linfocítico em relação ao neutrofílico (4:1).

Tan et al. (2004) reportaram o lúpus eritematoso discóide como o principal diagnóstico $(33,9 \%)$, seguido pela pseudopelada de Brocq $(24,1 \%)$ e pelo líquen plano pilar (22,3\%). No estudo feito por Whiting (2003), que também mostrou um aumento das alopecias cicatriciais primárias linfocíticas, houve um predomínio da pseudopelada de Brocq $(40,6 \%)$, seguida pelo líquen plano pilar $(12,6 \%)$ e pela foliculite decalvante $(11,2 \%)$. Diferenças demográficas entre os pacientes e critérios clinicopatológicos controversos para o diagnóstico de pseudopelada, provavelmente 
contribuíram para essa disparidade entre os principais diagnósticos. (Ross et al.,2005).

\subsection{Alopecias Cicatriciais Primárias Linfocíticas.}

\subsubsection{Lúpus Eritematoso Discóide (LED).}

O padrão de alopecia associada ao lúpus eritematoso (LE) pode se apresentar como cicatricial e não cicatricial, sendo este último reversível se a doença primária for tratada (Sperling e Cowper, 2006)

O LED geralmente ocorre em adultos e é mais comum em mulheres, que iniciam a doença em torno de 20 e 40 anos. É raro em crianças e não tem uma predileção racial clara (Otberg et al, 2008). Apesar de lesões discóides poderem ser vistas em pacientes com LE sistêmico, a maioria dos pacientes com LED não apresenta doença sistêmica. Dentre os pacientes com LED em torno de 30-50\% terão lesões no couro cabeludo (Ristrepo et al., 2005), destes 5 a 10\% dos adultos e em torno de $30 \%$ das crianças, irão em algum momento, desenvolver LE sistêmico (Sperling e Cowper, 2006).

As variantes cicatriciais do lúpus eritematoso são tipicamente vistas em pacientes com a forma de lúpus eritematosos discóide. Lesões discóides são formas de apresentação do lúpus eritematoso cutâneo crônico (LECC), e enquanto o uso deste termo está aumentando, o nome lúpus eritematoso discóide (LED) permanece embutido no nosso dicionário (Sperling e Cowper, 2006).

A causa e a patogênese do LED são desconhecidas. A complexa interação de fatores genéticos, ambientais e do doente determina a expressão da doença. A 
"Koebnerização", por exemplo, deve ser levada em consideração para a patogênese do LED do couro cabeludo, neste paradigma, traumas mundanos como arranhar ou escoriar o couro cabeludo, podem provocar ou agravar a doença em indivíduos afetados (Ross et al., 2005).

A Relevância da luz ultravioleta para o desenvolvimento de LED, em áreas relativamente pouco expostas do couro cabeludo, ainda não foi totalmente explorada. Da mesma forma um pequeno estudo mostrou que pacientes com queixa de fotossensibilidade não desenvolveram formas mais graves de LED (Ross et al., 2005).

Clinicamente, as lesões do couro cabeludo podem lembrar as lesões de lúpus discóide clássico em qualquer outra localização, e em geral apresentam-se com eritema inicial que progride para áreas de atrofia epidérmica, com óstios foliculares ceratósicos e dilatados além da alopecia, telangiectasia e hipopigmentação central com hiperpigmentação periférica (sendo esta última forma de apresentação vista mais comumente em pacientes negros). $\mathrm{O}$ eritema, as alterações pigmentares e a escamação folicular são mais pronunciadas no LED que nas demais formas de apresentação das alopecias cicatriciais (Sperling e Cowper, 2006). O teste de tração pode ser positivo para cabelos anágenos (Otberg et al, 2008).

A distribuição e o grau de inflamação clínica variam entre os pacientes. As lesões do couro cabeludo podem lembrar também alopecia areata, líquen plano pilar, morféia linear, alopecia central centrífuga e pseudopelada de Brocq. Do mesmo modo, a incidência da alopecia areata concomitante é maior em pacientes com LED, e uma forma rara de paniculite lúpica envolvendo a porção inferior do folículo manifestando-se como uma forma transitória de alopecia, similar a alopecia areata, 
também já foi documentada. Portanto, um exame minucioso de todas as áreas calvas é obrigatório para fazer a distinção entre as diferentes formas de alopecia (Ristrepo et al., 2005).

A madarose pode estar presente mesmo na ausência do envolvimento do escalpo, por isso, a necessidade da confirmação histológica, não deveno confiar o diagnóstico apenas pela aparência clínica (Sperling e Cowper, 2006). A biópsia também é mandatória em lesões de longa data de LED, as quais são propensas a desenvolver carcinomas de células escamosas, com uma alta ocorrência de metástases; portanto, placas hiperceratósicas ou ulceradas devem ser precocemente biopsiadas (Otberg et al., 2008).

Quanto aos sintomas, lesões ativas podem ser assintomáticas, mas os pacientes podem queixar-se, além da perda dos cabelos, de prurido, queimação e hipersensibilidade local, e podem reportar piora após a exposição ultravioleta (UV) (Ross et al., 2005).

$\mathrm{Na}$ evolução da doença, lesões pequenas ou em placas, podem confluir e progressivamente acometer uma extensa área do escalpo. Remissão espontânea pode ocorrer num período de 4 anos em um terço a um quarto dos indivíduos acometidos, sendo essa porcentagem menor, naqueles com doença extensa (Otberg et al., 2008).

O LED histologicamente demonstra hiperqueratose e rolha córnea folicular (que consiste em óstios dilatados e infundíbulo cheio de queratina correspondendo aos "plugs" ou tamponamentos folicular, observados clinicamente), atrofia do estrato malpiguiano e alteração vacuolar das células da membrana basal do epitélio folicular e epidérmico com presença de queratinócitos disqueratósicos (Ross et al., 2005). A epiderme interfolicular é comumente afetada em contraste com o LPP cujo 
acometimento da derme interfolicular é inconstante. Em um estudo recente comparando o LED com o LPP, o envolvimento da epiderme era comumente visto no lúpus, em oposição ao LPP, onde na maioria das vezes o alvo era somente o folículo capilar (Ross et al., 2005).

$\mathrm{Na}$ derme, o infiltrado inflamatório é encontrado ao redor do plexo vascular (superficial e profundo) e perianexial, especialmente periécrino. No folículo, o infiltrado inflamatório se localiza preferencialmente no infundíbulo e istmo; e no tecido subcutâneo, podem ser observados em alguns casos a formação de folículos linfóides (Sehgal et al., 2001).

As glândulas sebáceas são frequentemente destruídas no início do processo e na fase tardia, o folículo inteiro é perdido (Ross et al., 2005).

A presença de uma membrana basal espessada, positiva ao ácido periódico de Schiff (PAS) é comum nos achados histológicos de lesões crônicas de LED, e tem potencial para diferenciar o LED do LPP, mesmo em uma fase adiantada (Ross et al., 2005).

Adicionalmente, a coloração para tecido elástico pode ser de grande valia para ajudar a diferenciar os pacientes com LED do couro cabeludo, dos outros tipos de alopecia cicatricial. Em lesões de LED no estagio final, existe uma fibrose em toda a derme reticular com uma concomitante perda de fibras elásticas apreciada pelas colorações específicas. Nas lesões da fase tardia do LPP, no entanto, há uma cicatriz superficial em forma de cunha, com destruição da rede de fibras elásticas apenas nesta área. A coloração para tecido elástico também auxilia na diferenciação dessas entidades com a pseudopelada de Brocq na qual as fibras elásticas não se perdem, mas, ao contrário, muitas vezes se tornam espessadas (Ross et al., 2005). 
Em relaçao aos exames complementares o FAN encontar-se positivo em até 42,8 $\%$ dos pacientes com lesão no escalpo (Fabbri et al, 2004). A IFD mostra um deposito linear ou granular de $\operatorname{IgG}$ e C3 (menos comumente IgM ou IgA) na junção dermo-epidérmica e/ou na junção do epitélio folicular e derme. Depósitos inespecíficos de IgM na forma globular podem ser vistos nos corpos citóides. Uma IFD positiva está presente em $63-100 \%$ dos casos, o que pode ajudar a diferenciar alguns casos difíceis de LED, do LPP (Somani e Bergfeld, 2008). A fim de otimizar o rendimento do exame de IFD, uma lesão de duração de 2-3 meses deixada sem tratamento por três semanas deve ser selecionada (Otberg et al., 2008).

Terapia de primeira linha para pacientes com LED lentamente progressivo e limitado, deveria ser feita com acetonido de triancinolona intralesional em uma concentração ideal de $10 \mathrm{mg} / \mathrm{ml}$ a cada 4 a 6 semanas com ou sem corticosteróides tópicos associados, os quais mesmo isoladamente, mostraram ser igualmente eficazes para as formas mais brandas de LED. A hidroxicloroquina também tem mostrado ser altamente eficaz, embora deva ser iniciada com uma dose de 200 a $400 \mathrm{mg}$ por dia, em adultos, ou 4 a $6 \mathrm{mg} / \mathrm{kg}$ em crianças. Um exame oftamológico inicial e hemograma completo são necessários antes da terapia ser iniciada. A terapia oral inicial (de ponte) feita com predinisona pode ser iniciada com $1 \mathrm{mg} / \mathrm{kg}$ e diminuída durante as primeiras 8 semanas de tratamento, podendo ser útil em pacientes com doença de progressão muito rápida. Retinóides orais também têm se mostrado eficazes; acitretina na dose de 50mg por dia e isotretinoina na dose de $40 \mathrm{mg}$ duas vezes ao dia têm sido sugeridos. Terapias sistêmicas imunossupressoras, como o micofenolato de mofetil, metotrexato ou azatioprina devem ser considerados apenas se terapias anteriores falharem (Otberg et al., 2008). 


\subsubsection{Líquen Plano Pilar (LPP)}

O Líquen Plano Pilar é uma forma rara de alopecia cicatricial, descrita primeiramente por Pringle em 1985, que acomete frequientemente mulheres (70\%) e caucasianos e tem a idade media de apresentação de 51 anos. Aproximadamente $50 \%$ dos pacientes apresentam manifestações cutâneas concomitantes, acometimento de membranas mucosas ou alterações ungueais características de líquen plano (Ristrepo et al., 2005).

A etiologia do LPP permanece desconhecida, mas está provavelmente relacionada à (s) mesma (s) causa (s) do Líquen Plano (LP) como vítus e drogas. Casos de LPP foram descritos associados à exposição ao ouro, tireoidite imune, esclerodermia em golpe de sabre e dermatite herpetiforme (Ristrepo et al., 2005).

A forma clássica do LPP envolve comumente o vértex, mas qualquer área do couro cabeludo poder ser afetada. As lesões iniciais clássicas são caracterizadas por eritema violáceo folicular, geralmente localizado na periferia da zona alopécica, correspondendo à sua margem de expansão. O curso clínico e o padrão da queda do cabelo pode ser insidioso ou fulminante (Assouly and Reygagne, 2006).

O exame físico é variável mostrando diferentes características a depender do período de evolução clinica (fase inflamatória ou cicatricial). A fase inflamatória apresenta-se com eritema perifolicular e espículas foliculares cuja cicatrização resulta em perda de pelos com presença de ostios dilatados ora contendo debris queratoticos, ora com focos espalhados de alopecia parcial onde podemos observar saída de pelos através desses ostios (foliculite em tufos). O LPP pode apresentar 
também um padrão de alopecia semelhante à Alopecia Central Centrífuga ou a Pseudopelada de Brocq e infrequentemente pústulas podem ser observadas nas bordas da alopecia, o que poderia imitar a Foliculite Decalvante por isso o diagnostico de LPP não deve ser baseado somente em características clínicas (Ristrepo et al., 2005).

A evolução do LPP mostra alopecia em placas mimetizando as fases finais de diversas formas de alopecia cicatricial, essas placas apresentam-se de diferentes tamanhos e formas e são centrífugas e coalescentes, podendo afetar inteiramente o couro cabeludo. Ainda não existem estudos que mostrem a duração correta da doença, como se a mesma não tivesse um fim aparente ou remissão completa (Assouly and Reygagne, 2006).

Pacientes com doença do couro cabeludo indolente podem ser assintomáticos, mas o prurido e a hipersensibilidade estão freqüentemente presentes. Pacientes que apresentam concomitantemente líquen plano de pele ou de mucosa podem ter sintomas relacionados a essas lesões (Sperling e Shawn, 2006).

Nas fases iniciais da doença o teste de tração, como exame clínico complementar, mostra um aumento do numero de pelos anágenos. A dermatoscopia mostra ausência de orifícios foliculares no centro das áreas calvas; nas margens, o eritema inflamatório é perifolicular e a queratose estende-se ao longo do cabelo, com falsos "casts" (cilindros capilares) observados no seu eixo. O exame laboratorial complementar mais importante é a imunofluorescência direta e a pesquisa de anticorpos como o FAN, para diferenciar esta doença do Lupus Eritematoso Discóide e do Lupus Eritematoso Sistêmico, respectivamente (Ristrepo et al., 2005). 
Uma condição chamada 'Alopecia Frontal Fibrosante (AFF)' foi recentemente relatada acometendo mais frequentemente mulheres australianas, caucasianas e pósmenopausadas. São mulheres mais velhas (idade média 67 anos) com alopecia progressiva ao longo da linha frontal de implantação dos cabelos e sobrancelhas. As características histopatológicas são semelhantes àquelas encontradas no LPP. Para alguns estudiosos a AFF parece ser um padrão clínico da alopecia cicatricial associado ao LPP, apesar de lesões de LP de forma geral não serem encontradas nesses pacientes (Sperling e Shawn, 2006).

Já a síndrome caracterizada pela tríade: alopecia cicatricial do couro cabeludo, alopecia não cicatricial das regiões axilares e pubianas, e presença de pápulas foliculares ceratósicas agrupadas, lembrando Líquen Espinuloso ou Ceratose Pilar no tronco e extremidades está provavelmente relacionada ao LPP. Essa condição rara foi descrita por Piccardi em 1913 e publicada por Graham Little em 1915 (apud Sperling e Shawn, 2006) levando o nome de ambos.

Achados histológicos do LPP e suas variantes nos estágios iniciais consistem em alterações vacuolares de interface, com infiltrado celular linfocítico liquenoide perifolicular, hipergranulose, hiperqueratose, hiperacantose, degeneração de queratinócitos basais e destruição da camada basal na metade dos casos. Um infiltrado em banda subepidérmico pode estar presente envolvendo ("hugging") a região entre o infundíbulo e o istimo, tipicamente poupando a porção inferior cíclica do folículo (Sperling e Shawn, 2006).

Ocasionalmente, a epiderme interfolicular pode estar associada a um infiltrado liquenoide focal, mas o clássico infiltrado em banda visto no líquen plano poucas vezes está presente. O infiltrado resulta na vacuolização da camada basal, com 
corpos citóides e a formação de uma fenda artefatual entre o epitélio e o estroma chamada de espaço de "Max Joseph". A incontinência pigmentar pode ser proeminente, especialmente nos poucos casos envolvendo a epiderme. Nos achados histológicos nem todos os folículos pilosos parecem estar envolvidos, correspondendo à perda de cabelo, muitas vezes incompleta, observada clinicamente nas placas individuais de LPP (Sellheyer K and Bergfeld, 2006). Os folículos acometidos estão dilatados com suas extremidades arredondadas, mostrando uma aparência em "forma de copo" preenchido com material queratinoso correspondendo às rolhas córneas ou pápulas perifoliculares ceratósicas ao exame clínico (Sperling e Shawn, 2006).

Glândulas sebáceas são destruídas no início do processo. Já o plexo vascular profundo ou outras estruturas anexiais, como as glândulas écrinas, não estão envolvidos (Sellheyer and Bergfeld, 2006).

$\mathrm{O}$ acometimento do istmo e do infundíbulo correlacionam-se com a cicatriz tardia em forma de cunha das fases adiantadas do LPP, nesta fase ocorre uma a fibrose perifolicular lamelar concêntrica, os folículos são destruídos e substituídos por um trato fibroso espesso, a inflamação é mínima ou ausente, sem alterações liquenóides clássicas (Sellheyer and Bergfeld, 2006).

Colorações especiais mostram depósito de mucina perifolicula e ausente na derme interticial. As colorações para fibra elástica foram úteis em diferenciar o LPP do LED. A perda de tecido elástico vista em coloração própria, envolvendo apenas a porção do terço superior, levando a uma cicatriz superficial em cunha com destruição da rede de fibras elásticas somente nesta área, associada à destruição da bainha 
elástica que margeia o trato fibroso auxilia no diagnostico diferencial do LPP mesmo na fase tardia (Sellheyer and Bergfeld, 2006).

Os achados de imunofluorescencia direta são inespecíficos mostrando deposito de $\operatorname{IgM}$ e menos frequentemente de $\operatorname{IgA}$, IgG e C3 dentro de corpos citóides ao redor da porção superior do folículo (Sellheyer and Bergfeld, 2006).

O LPP pode ser uma condição particularmente difícil de tratar. As recomendações de tratamento incluem antimaláricos por via oral (p.ex. hidroxicloroquina e griseofulvina tem tido resposta nos paciente com líquen plano) e corticosteróides (tópicos; intralesionais assim como no LED. Sugere-se usar o acetonido de triancinolona intralesional em uma concentração ideal de $10 \mathrm{mg} / \mathrm{ml} \mathrm{a}$ cada 4 a 6 semanas 12 com ou sem corticosteróides tópicos; e sistêmicos como terapia de ponte na primeira semana nos casos ativos). Vários estudos isolados ou não controlados relatam que a ciclosporina oral 300mg/dia por mais de 3-5 meses, o micofenolato mofetil oral, retinóides sistêmicos (como a isotretinoina 10mg/dia ou a acitertina 30mg/dia) e metotrexate oral, em baixas doses semanais, podem ser eficazes em alguns pacientes. Esses últimos devem ser usados com cautela, já que podem ser causar algum grau de alopecia (Sperling,2008; Otberg et al., 2008).

$\mathrm{Na}$ AFF, uma dose baixa de acetonido de triancinolona intralesional $(2,5$ a 5mg/ml) assim como o uso de minoxidil tópico devem ser considerados, apesar de resultados efetivos não terem sido reportados. O tratamento da síndrome de Graham Little é tipicamente similar ao do LPP. Um tratamento efetivo para as sobrancelhas até o momento não foi identificado (Otberg et al.,2008).

\subsubsection{Pseudopelada Classica (de Brocq)}


Em 1888, Brocq citado por Ross et al. (2005) comparando com a "la pelade” ou perda de cabelo da alopecia areata, descreveu uma forma de alopecia cicatricial progressiva, idiopática e não inflamatória que ele denominou de pseudopelada. Em 1905, Brocq e colaboradores apud Ross et al. (2005), detalharam exaustivamente características clinicas da doença baseados em revisões de casos publicados e em seus próprios casos e concluíram que a pseudopelada era uma entidade nosologica única.

Esta definiçao que foi debatida por vários de seus contemporâneos e por muitas décadas tem sido motivo de muita confusão na literatura. Muitos continuam mantendo o termo como uma entidade distinta, outros preferem usar pseudopelada de Brocq (PB), sem especificidade, ora para denominá-la como uma variante de outras formas de alopecia, ora considerando a doença como um estágio final comum de outras alopecias cicatriciais. Alternativamente outros preferem abandonar o termo pseudopelada completamente (Ross et al.,2005).

A pseudopelada de Brocq será melhor discutida adiante, preferimos neste trabalho manter esta classificação, por acreditar que a mesma apresenta características clínico-patológicas que suportam o conceito de uma entidade distinta.

As lesões clínicas da PB podem variar muito no seu modo de expressão, pela relativa raridade e pela falta de familiaridade entre médicos não dermatologistas, por isso, lesões na fase inicial são menos frequentes que lesões na fase tardia. Os pacientes têm história de ter passado por vários médicos e por longos tratamentos (Headington, 1996). 
Estudos detalhados feitos por Braun-Falco e colaboladores (citado por Amato et al.,2002), definiram critérios diagnósticos clínicos que apresentam a clássica PB como uma doença que ocorre em mulheres brancas de meia idade (30 a 50 anos) apresentando numerosas placas alopécicas (usualmente mais de 10) localizadas no escalpo, preferencialmente no vertex ou coroa. Brocq descreveu três formas de apresentação, uma com distribuição em confete, outra coalescendo em placas grandes e irregulares com bordas policíclicas (Amato et al.,2002), algumas vezes rodeadas por placas menores satélites e uma terceira forma que seria uma combinação dessas duas apresentações (Ross et al.,2005).

No estágio inicial, a doença caracteriza-se por leve eritema com inflamação discreta ou inexistente e ausência de hiperqueratose folicular (Amato et al.,2002). Raramente uma leve descamação pode estar presente em torno dos orifícios foliculares (Ross et al.,2005).

Em geral a doença é assintomática, mas um leve prurido e hiposensibilidade local podem estar presentes (Ross et al.,2005). As placas alopecicas têm longo curso (pelo menos de dois anos) com progressão lenta, mas podem mostrar regressão espontânea e no estágio final uma atrofia leve pode ser observada em muitos pacientes (Amato et al.,2002).

Em brancos de pele clara, uma revisão de textos e fotografias feitas por Brocq e citadas por Ross et al. (2005), mostraram lesões de cor marfim e branco perolado. Em outras raças, com as mesmas características morfológicas, as lesões são tipicamente hipopigmentadas, mas também podem aparecer difusamente bronzeadas ou cor de carne, refletindo talvez as mudanças pós-inflamatórias ou a exposição 
destas áreas nuas ao sol. Algumas lesões típicas são hipopigmentadas e deprimidas e foram classicamente descritas como "pegadas na neve". (Ross et al.,2005)

Dentro de grandes áreas de alopecia cicatrizada, poucos pêlos terminais podem permanecer (Ross et al.,2005), o paciente usualmente com uma lesão no estágio final tem uma área bem definida de alopecia com ausência da maioria dos orifícios foliculares na superfície do couro cabeludo. Em pacientes com cabelo liso, fios de cabelo remanescentes podem aparecer, paradoxalmente, encaracolados (Headington, 1996).

Embora acometa na grande maioria das vezes o couro cabeludo de mulheres de meia idade, casos isolados de PB concomitante na área da barba e em crianças já formas descritos (Ristepo et al., 2005). E apesar de apresentar-se com curso lento e com períodos de atividade e quiescência, como descrito anteriormente, uma forma rara de alopecia aguda, difusa e extensa também pode ser encontrada (Headington, 1996) o que continua a alimentar o debate sobre a natureza da doença.

A etiologia da PB permanece desconhecida e para aqueles que a consideram uma entidade distinta, autoimunidade adquirida, infecção causada por Borrelia e senescência prematura da reserva folicular de células-tronco, têm sido postulados como fatores patogênicos (Ross et al.,2005).

Por apresentar quadro inflamatório, mesmo que mínimo, para o diagnostico deve-se excluir as outras formas de alopecias cicatriciais. O teste de tração das lesões ativas mostra invariavelmente cabelos anágenos, o que raramente é encontrado em outras formas de alopecia, exceto na forma aguda do LPP e ocasionalmente no LED (Headington, 1996). 
Os achados histológicos de lesões ativas não mostram, em contraste com o LPP e com o LED, alteração de interface (Headington, 1996). Lesões precoces revelam ausência ou apenas um escasso a moderado infiltrado perifolicular e perivascular linfocítico, especialmente em torno do infundíbulo folicular (Sellheyer e Bergfeld, 2006), mas podendo ocorrer em todos os níveis do folículo (Ross et al.,2005).

Em lesões avançadas o epitélio folicular é inteiramente destruído e pêlos nus podem permanecer orientados verticalmente como corpos estranhos. Os fios de cabelo são rodeados por histiócitos e células inflamatórias gigantes de corpo estranho. Tratos fibrosos residuais de folículos capilares localizados na derme reticular e no tecido subcutâneo superficial também marcam os locais dos folículos destruídos. Uma fibroplasia lamelar concêntrica característica está presente em lesões iniciais, no entanto é mais proeminente nas placas bem estabelecidas de alopecia (Ross et al.,2005). As glândulas sabáceas também são destruídas. Durante o curso da doença, a atrofia do epitélio folicular infundibular, muitas vezes resulta em uma localização excêntrica dos canais foliculares. Os folículos são normalmente cercados por tecido subcutâneo e músculo eretor do pelo residual pode se observado (Sellheyer e Bergfeld, 2006).

Em colorações especiais a preservação da rede elástica é uma característica marcante. Por isso, a utilização de colorações para fibras elásticas, além da coloração convencional por hematoxilina-eosina permite a diferenciação da PB do LPP e do LED, mesmo nas lesões em estágios avançados, na grande maioria dos casos, justificando a classificação do estado como uma entidade "sui generis" (Sellheyer e Bergfeld, 2006). 
A IFD revela somente um mínimo e ocasional depósito granular de IgM na zona de membrana basal do infundíbulo folicular (Sellheyer e Bergfeld, 2006).

O tratamento das lesões ativas é difícil e ainda não existem trabalhos controlados sobre este tema. Esteróides tópicos potentes têm pouco valor e corticóides intralesionais tem valor limitado. A hidroxicloroquina em doses diárias de 200 a 400mg é provavelmente efetiva se a duração do tratamento for suficientemente longa (6 a 12 meses). A eficácia terapêutica pode ser determinada pela mensuração das áreas acometidas e pelo teste de tração: se o teste de tração continuar anageno e as lesões permanecerem em atividade o tratamento deve ser continuado. Se as lesões estacionarem e o teste de tração for negativo por pelo menos 6 meses o tratamento medicamentoso deve ser descontinuado e uma redução do escalpo ou transplante capilar devem ser cogitados. A predinisona oral e a isotretinoina tem mostrado alguma eficácia no tratamento da PB (Headington, 1996; Otberg et al.,2008).

\subsubsection{Alopecia cicatricial central centrifuga (ACCC)}

O termo alopecia cicatricial central centrifuga, foi propagado na literatura mais recente e é definido como uma perda de cabelo que se inicia no escalpo central com progressão centrifuga. É um termo descritivo e pretende abranger outras entidades anteriormente designadas como síndrome da degeneração folicular, pseudopelada em afro-americanos, e pseudopelada elíptica central em caucasianos. Esta condição tem uma considerável sobreposição histopatológica com a pseudopelada clássica de Brocq, daí o uso do termo pseudopelada nas duas últimas variantes de ACCC. No entanto, com a sua localização central no couro cabeludo e sua forma de expansão, 
esta alopecia é clinicamente distinta da forma clássica da pseudopelada de Brocq, na qual os pacientes afetados apresentam-se tipicamente com várias placas alopecicas, muitas vezes numerosas e irregulares (Ross et al., 2005).

ACCC é a forma mais comum de alopecia cicatricial em qualquer população que inclua um número de pacientes negros. Entre os afro-americanos, a ACCC é responsável por mais casos de alopecia cicatricial que todas as outras formas combinadas. A maioria dos pacientes negros com ACCC são mulheres, com uma razão mulher: homem de 3:1 (Sperling, 2008).

A patogênese da ACCC é desconhecida, a síndrome de degeneração folicular, como uma das entidades incluídas na ACCC, foi inicialmente descrita como "alopecia do pente quente (hot comb alopecia)" e foi pensado ser devida ao dano do couro cabeludo pelo petrolatum quente utilizado em alguns tipos de técnicas para cabelos afro-americanos. Aparentemente todas as mulheres afro-americanas com ACCC usam ou usaram relaxantes capilares químicos para embelezamento, mas poucos homens usaram algum destes, exceto pomadas. Os pacientes apresentam progressão da doença mesmo após todos os tratamentos químicos (se algum) serem descontinuados. Cosméticos cáusticos ou o uso de 'pentes quentes' podem agravar a doença ou acelerar sua progressão, mas não podem explicar a patogênese por completo (Sperling, 2008).

A hipótese de Sperling (2003) citada por Ross et al. (2005) é que a condição seja resultado de uma degeneração precoce da bainha radicular interna em pacientes que estejam predispostos ao dano folicular devido à anormalidade anatômica, chamada descamação prematura da bainha radicular interna, esse defeito estrutural da parede folicular pode predispor os folículos afetados à injúria ou inflamação, por isso a 
denominação de síndrome de degeneração folicular. Essa degeneração, no entanto, pode ser vista ocasionalmente em outras condições em que os folículos são expostos à inflamação importante e alterações degenerativas, permanecendo o debate sobre a natureza da doença (Sperling, 2008).

Segundo Sellheyer e Bergfeld (2006) alguns autores não consideram a síndrome de degeneração folicular, como uma entidade clinico-patológica distinta e referem-se às alterações histopatológicas que lhe são atribuídas como sendo não específicas, pois podem ser vistas em outras formas de alopecias cicatriciais. Ackerman e colaboradores (apud Sellheyer e Bergfeld, 2006) acreditam que a síndrome de degeneração folicular seja uma forma de alopecia de tração.

A doença começa e permanece mais grave na coroa ou vértice do couro cabeludo, expandindo-se lenta e progressivamente de forma simétrica e centrífuga. As cicatrizes na pele são flexíveis, brilhantes, cor de carne. Hiperpigmentação perifolicular e poucos pêlos isolados, alguns apresentando politriquia (em tufos como em "cabelo de boneca" ou escova de cabelos) podem ser encontrados na zona central desnuda (Somani e Bergfeld, 2008). A síndrome da degeneração folicular em homens é comumente marcada por uma característica adicional perifolicular, com presença de pápulas inflamatórias nas áreas de perda de cabelo (Ross et al., 2005).

Sintomas podem ser leves ou ausentes. A maioria dos pacientes apresenta apenas prurido ocasional, ou sensibilidade na área acometida. Doença de longa data ou grave pode resultar em perda dos cabelos de todo topo do couro cabeludo e ainda não está claro se, a parada do trauma e a química sobre os cabelos alteraria o curso da doença. Outras formas de alopecia cicatricial primária também podem coexistir com a ACC (Ross et al., 2005). 
Pústulas e crostas podem ser encontradas em uma minoria de pacientes que sofrem progressão rápida da doença ou infecção bacteriana secundária, podem ser multifocais, mas eventualmente surgem dentro de uma placa maior no vértice. De qualquer forma, um curso de 2-3 semanas de corticosteróides ou antibióticos sistêmicos pode eliminar temporariamente o componente purulento da ACCC (Sperling, 2008).

A área mais importante para a biopsia é a periférica a uma região com alopecia, mas mesmo o couro cabeludo aparentemente 'normal' a muitos centímetros da área clinicamente envolvida pode estar doente ao microscópio. Nem todos os folículos de uma mesma área estão envolvidos simultaneamente. Um fragmente de biópsia por punch de $04 \mathrm{~mm}$ pode conter apenas um ou dois folículos 'diagnósticos'. Isso se deve ao fato dos folículos envolvidos serem seletivamente destruídos, poupando os folículos relativamente normais. Na maioria dos casos, cortes transversais em vários níveis são necessários para um diagnóstico definitivo (Sperling, 2008).

A literatura sobre a histopatologia da ACC não é extensa. As características histológicas à coloração por HE consistem na descamação prematura da BI além de uma foliculite linfocítica proeminente com destruição das unidades foliculares semelhante à observada na pseudopelada de Brocq clássica, muito embora a apresentação clínica diferente pareça justificar a separação da ACCC desta última (Ross et al., 2005).

Para a doença relativamente não inflamatória, a combinação de tetraciclina oral de longa ação (por exemplo, doxiciclina ou minociclina) mais um corticosteróide tópico de alta potência (por exemplo, clobetasol) são geralmente suficientes para parar a progressão da doença. Esse regime pode ser mantido seguramente por anos, 
sendo geralmente necessário para essa doença crônica. Para casos com muita inflamação, um regime inicial de 10 semanas de rifampicina oral e clindamicina (ambos 300mg duas vezes ao dia) mostraram-se eficazes (Otberg et al., 2008).

\subsubsection{Alopecia Mucinosa (AM)}

A alopecia mucinosa pode estar associada ou não a uma alopecia permanente, já a forma permanente, não está associada com uma cicatriz histológica verdadeira (Otberg et al, 2008). A entidade existe tanto como uma desordem idiopática, como uma expressão secundária da micose fungóide (MF), embora esta distinção tenha sido recentemente contestada. A designação descritiva de mucinose folicular referese ao denominador comum de ambas as apresentações, que é a deposição de mucina no interior da unidade folículo-sebácea. A mucinose folicular não é exclusiva da alopecia mucinosa, mas representa um padrão de reação histopatológica no epitélio folicular observado em uma grande variedade de condições não relacionadas etiologicamente (Sellheyer e Bergfeld, 2006).

Ambas as formas de alopecia mucinosa afetam todas as faixas etárias e se apresentam como pápulas foliculares agrupadas, manchas eritematosas e / ou placas edematosas, mais comumente na região da nuca e da cabeça e também no tronco e extremidades (Sellheyer e Bergfeld, 2006). Alopecia difusa e áreas alopécicas lembrando alopecia areata são outras formas de apresentação clínica conhecidas. A alopecia pode envolver também as sobrancelhas e o tronco (Otberg et al., 2008).

Assim como a apresentação clínica, não existe um critério histopatológico, que permita uma diferenciação reproduzível e consistentemente confiável para a 
diferenciação da alopecia mucinosa idiopática daquela associada com a micose fungóide folicular. Em contraste com o que se acreditava, a atipia citológica pode ser vista em ambas as formas, apoiando o conceito de que a alopecia mucinosa é micose fungóide (Boer e Ackerman, 2004). Um estudo mostrou um predomínio de eosinófilos no infiltrado da alopecia mucinosa idiopática, em oposição aquela associada com a MF folicular, porém isso não foi confirmado por outros estudos. Talvez um infiltrado linfocítico em banda nas proximidades da epiderme interfolicular, mas sem vacuolização epidérmica possa favorecer a alopecia mucinosa associada ao linfoma, mas de modo algum exclui a forma benigna. Espongiose folicular e epidermotropismo podem ser vistos nas duas variantes (Sellheyer e Bergfeld, 2006).

A alteração histopatológica inicial é a deposição de mucina na bainha radicular externa, que acaba por envolver o folículo piloso inteiro, incluindo as glândulas sebáceas. Linfócitos estão presentes perifolicular e intrafolicular e também em vários graus dentro da derme. Na derme, pode ser visto infiltrado perivascular superficial, superficial e profundo ou uma distribuição difusa (Sellheyer e Bergfeld, 2006).

Determinadas características, especialmente quando vistas em combinação, são sugestivas, mas não significam decisivamente o diagnóstico de linfoma relacionado à doença: 1. microabscessos de Pautrier no epitélio folicular; 2. infiltrado dérmico difuso e nodular não limitado a adventícia; 3. células atípicas com núcleos cerebriformes vistos em uma distribuição em banda; 4. características epidérmicas ou periécrinas de infiltração maligna. O significado destes achados só pode ser plenamente interpretado quando relacionados ao contexto clínico. Múltiplas biópsias 
podem ser necessárias antes de um diagnóstico definitivo poder ser feito, exceto em casos de alopecia mucinosa paraneoplásica (Ross et al., 2005).

O tratamento deve ser direcionado para a origem da alopecia, então, um exame clínico acurado deve ser realizado em todos os pacientes incluindo palpação de linfonodos. Um trabalho completo até excluir uma malignidade subjacente, como a MF e Sindrome de Sézary é necessário. Nenhuma terapia padrão de alopecia mucinosa está disponível até o momento. Corticosteróides orais, micociclina e isotretinoina têm se mostrado eficazes. Corticosteróides tópicos e intralesionais, dapsona, indometacina e fototerapia também têm sido utilizados com resultados variáveis (Otberg et al., 2008).

\subsubsection{Ceratose Folicular Espinulosa Decalvante (CFED)}

A ceratose folicular espinulosa decalvante é uma desordem ligada ao cromossoma $\mathrm{X}$, de causa desconhecida. Está intimamente ligada à ceratose atrofiante da face (também chamada "ulerythema ophryogenes") e a atrofodermia vermiculata, que acomete principalmente a face. A CFED geralmente se desenvolve durante a adolescência e apresenta-se principalmente como uma alopecia cicatricial com pápulas foliculares ceratósicas, e raramente pústulas. $\mathrm{O}$ envolvimento das sobrancelhas e cílios também pode estar presente. Sintomas adicionais incluem ceratose pilar do tronco e extremidades, assim como fotofobia e distrofia córnea.

A sociedade norte americana de estudiosos de cabelo classifica a alopecia cicatricial que ocorre na CFED como primária linfocítica. Considerando que esta classificação seja verdadeira em pleno desenvolvimento e nas fases finais da CFED. 
Durante as fases precoces desta alopecia neutrófilos podem ser vistos. A primeira mudança, no entanto, consiste na obstrução do infundíbulo folicular acompanhada de hipergranulose. Na fase aguda inflamatória seguinte, neutrófilos e espongiose são observados na epiderme e infundíbulo circundante. Com a progressão da doença, surge um infiltrado linfocítico e uma fibrose perifolicular, especialmente em torno do infundíbulo e istmo. Destruição completa e cicatrização com fibrose do folículo piloso constituem o estágio final da doença.

O diagnostico diferencial é feito pela história clínica e inclui LPP e foliculite decalvante. Os aspectos que ajudam na distinção histológica são a espogiose peri e intrafolicular e a presença de neutrófilos nas lesões agudas (Somani e Bergfeld, 2008).

Pela idade de acometimento da doença, que ocorre em adolescentes, devem ser pesados os riscos e benefícios do tratamento que inclui corticóides tópicos e intralesionais e retinóides orais, os quais apresentaram alguma eficácia (Otberg et al., 2008).

\subsection{Alopecias Cicatriciais Primárias Neutrofílicas.}

Foliculite Decalvante (FD) e Foliculite Abscedante/ Dissecante (FA) juntamente com as alopecias cicatriciais de padrão inflamatório misto compartilham de uma fase supurativa. Nódulos firmes e elásticos e indurações podem ser observados em várias fases da evolução da doença, em cada uma dessas condições. As alopecias cicatriciais neutrofílicas na fase inicial mostram foliculite supurativa envolvendo as porções superficiais do folículo capilar e um infiltrado linfoplasmocitário em torno 
do folículo inferior. Posteriormente as unidades pilossebáceas são perdidas. Fibroplasia interfolicular e cicatrizaçao difusa dérmica com perda de tecido elástico podem ser vistas.

\subsubsection{Foliculite decalvante (FD)}

A FD é uma forma de alopecia cicatricial primária relativamente comum, compreendendo $10,7 \%$ a $11,2 \%$ dos casos de alopecia cicatricial. Ocorre predominantemente em jovens e adultos de meia-idade, e afeta tanto homens e mulheres em igual número (Otberg et al, 2008). A doeça pode apresntar caráter familiar, sendo descrita em gêmeos idênticos sem anormalidade imunlógica identificável (Douwes et al., 2000) e em duas famílias com doenças hereditárias da função bacteriolítica de neutrófilos e da imunidade celular (Shitara et al., 1974).

As lesões primárias se apresentam como "pontinhos" de pústulas ou pápulas eritematosas foliculares que podem ser dolorosas ou pruriginosas. Com a progressão da doença, mais pústulas e pápulas, bem como a formação de crostas e nódulos podem ser vistos. Papulo-pústulas vizinhas aparecem breve, e podem evoluir para "abscessos miliares". Associadas com a atividade inflamatória, uma ou mais áreas redondas e irregulares de alopecia cicatricial se desenvolvem na região central, com cicatrizes alopecicas atróficas cor de carne ou branco-marfim, parecendo pseudopelada. Essas áreas podem estar rodeadas por pústulas foliculares e crostas que muitas vezes progridem perifericamente, parecendo uma "zona de foliculite" (Ross et al., 2005). 
Em casos graves, o envolvimento de múltiplos locais, bem como a coalescência das lesões pode ocorrer. Lesões de FD são tipicamente descritas acometendo a parte superior do couro cabeludo, mas outros estudos não notaram predileção de local específico (Otberg et al, 2008). O acometimento da barba (sicose lupoide), medial das coxas, axila e áreas púbicas pode ocorrer (Ross et al., 2005).

Foliculite com tufos é vista com freqüência na FD e caracteriza-se por múltiplos cabelos (5 a 15) emergindo de um orifício folicular dilatado na área inflamatória cicatricial, semelhante a "cabelo de boneca". Embora alguns autores considerem os tufos de cabelo uma característica patognomônica da foliculite decalvante, existe uma divergência de que esta manifestação seja uma forma inespecífica, devida sua ocorrência na fase final de uma ampla gama de alopecias cicatriciais primárias e secundárias (Otberg et al., 2008).

Embora a gravidade da inflamação varie, o curso da doença é geralmente crônico e lentamente progressivo. Transporte intranasal de S. aureus, presença de uma taxa de sedimentação elevada de eritrócitos no soro além de anticorpos antiestafilococicos são ocasionalmente registrados (Ross et al., 2005).

Geralmente o $S$. aureus é cultivado de uma foliculite supurativa e tem sido implicado na sua gênese por alguns autores. A predisposição para infecção do hospedeiro devida a déficits imunitários sistêmicos ou locais, e propriedades de cepas de $S$. aureus foram citados como fatores causais. Distúrbios imunes adquiridos ou hereditários têm sido associados com a FD, no entanto, a maioria dos pacientes afetados não tem nenhuma anomalia imunológica sistêmica ou lesional demonstrável. Pode ser que os fatores de virulência de estirpes específicas de $S$. 
aureus, incluindo a produção de superantígenos e a persistência intracelular após a fagocitose contribuam para a expressão da doença (Ross et al., 2005).

A característica histológica primária é a dilatação folicular acneiforme com um infiltrado neutrofílico intra e perifolicular que afeta a parte superior e média do folículo piloso, além do tamponamento folicular. A inflamação crônica resulta no afinamento excêntrico da bainha radicular externa e fibroplasia lamelar concêntrica. Uma posterior ruptura folicular resulta em mais inflamação interticial e perifolicular. Linfócitos, histiócitos e notavelmente células plasmáticas são recrutadas, fato este ser supostamente uma pista útil para o diagnóstico de casos avançados. Abscessos neutrófilicos estão mais comumente presentes do que na foliculite abscedante (FA); no entanto, ao contrário da FA o trato fistuloso é geralmente ausente na FD. Células gigantes de corpo estranho ao redor de fragmentos de fios de cabelo nus na derme estão freqüentemente presentes. A doença no estágio tardio é caracterizada pela substituição dos folículos pilosos por um trato fibroso. A bainha elástica que margeia o trato fibroso é perdida. Uma perda das fibras elásticas superficiais em forma de cunha vista pela coloração especifica semelhante à vista no LPP é descrita. Em casos de inflamação mais extensa, uma cicatriz dérmica difusa folicular associada à perda dos músculos eretores do pêlo é apreciada. A coloração de Gram para bactérias mostra comumente cocos gram-positivos de $S$. aureus e a coloração de PAS deve sempre ser realizada para excluir uma infecção fúngica. Cultura e antibiograma para bactérias também devem ser realizados (Somani e Bergfeld, 2008).

O tratamento é muitas vezes insatisfatório. Tentativas de erradicar o $S$. aureus é a abordagem de primeira linha. O tratamento inicial com o uso de antibióticos estafilocócicos de largo espectro, como a minociclina, eritromicina, cefalosporinas, 
sulfametoxazol-trimetropina é variávelmente eficaz e a recaída muitas vezes pode ser observada após a interrupção do antibiótico. Outros antibióticos que podem induzir por mais tempo a remissão da doença são a rifampicina, a clindamicina, e o acido fusidico. A rifampicina $600 \mathrm{mg}$ sozinha ou em combinação com clindamicina $600 \mathrm{mg}$ diária, suscitou uma boa resposta e nenhuma recaída durante um ano. O ácido fusídico oral pode ser usado sozinho ou em combinação com outros agentes. Pesquisas têm relatado uma boa resposta à terapia tripla com acido fusídico oral 1500mg por dia durante 3 semanas, sulfato de zinco 400mg diariamente por 6 meses e creme de acido fusídico por 3 semanas. A resposta ao tratamento inicial foi mantida com o sulfato de zinco 200mg por dia por mais de um ano. Corticosteróides intralesionais podem ser adicionados para controlar a inflamação aguda. Acetonido de triancinolona $10 \mathrm{mg} / \mathrm{ml}$ injetados mensalmente nos áreas de cabelo áreas que cercam as lesões cicatriciais de alopecia, podem impedir a progressão da doença e reduzir os sintomas de coceira e ardor. Antibióticos tópicos como mupirocina, ácido fusidico $1,5 \%$ e eritromicina $2 \%$ são usados geralmente com outros antibióticos orais. A erradicação intranasal de $S$. aureus com agentes antibacterianos tópicos também tem sido sugerida. Apenas dados limitados da eficácia, estão disponíveis sobre a administração oral de L-tirosina e isotretinoína para FD (Otberg et al., 2008).

6.13.2 Foliculite Abscedante/ Dissecante (FA):

A foliculite abscedante (FA) é uma doença incomum, mas distinta e frequentemente incapacitante. Faz parte da 'tétrade de oclusão folicular' que inclui hidradenite supurativa, cisto pilonidal e acne conglobata. Entretanto, a doença 
isolada do couro cabeludo é frequentemente observada. Afeta mais comumente homens adultos jovens, principalmente negros, mas pode ser vista (apesar de raramente) em mulheres caucasianas. Apesar da hiperceratose folicular ao invés da infecção parecer exercer papel principal na patogênese, a infecção bacteriana secundária pode ocorrer e como na FD o $S$. aureus ser isolado das lesões, além de outros agentes como estreptococos e pseudomonas (Sperling, 2008).

As lesões se iniciam com múltiplos nódulos firmes no couro cabeludo, mais comumente no topo, vértice e occipício superior. Os nódulos rapidamente evoluem para lesões ovais flutuantes, amolecidas, que eventualmente apresentam descarga de material purulento. As lesões frequentemente são intercomunicantes, de modo que a pressão em uma área flutuante pode resultar em descarga purulenta de outra área e este é um dos principais motivos que leva o paciente a procurar ajuda além da perda dos cabelos. Apesar da inflamação profunda maciça, surpreendentemente pode haver pouca ou nenhuma dor (Sperling, 2008).

Os primeiros achados histológicos são a presença de distensão acneiforme do infundíbulo folicular com tamponamento ceratósico e coleções de neutrófilos nos óstios foliculares. Subseqüentemente ocorre a ruptura na derme, seguida pela formação de abscessos subcutâneos. Fístulas revestidas por epitélio escamoso estratificado são achados marcantes que ajudam a diferenciar a FA da FD. Adicionalmente mediadores inflamatórios, incluindo linfócitos, células plasmáticas e células gigantes de corpo estranho são recrutados em uma fase tardia. Coloração para fungos e bactérias deve ser realizada. A coloração de Gram pode revelar bactérias na porção superficial do infundíbulo folicular dilatado, mas não dentro dos abscessos cutâneos (Somani e Bergfeld, 2008). 
Em raras ocasiões, a tinha do couro cabeludo pode se assemelhar a celulite dissecante. Outras formas muito inflamatórias de alopecia cicatricial (particularmente a foliculite decalvante) pode algumas vezes ser confundida com a foliculite abscedante (Sperling, 2008).

O tratamento divide-se em medicamentoso e cirúrgico.

Vários relatos de casos indicam que a isotretinoína $(0.5-1.5 \mathrm{mg} / \mathrm{kg} / \mathrm{dia}$ por 4 meses, mantida com $0,75-1 \mathrm{mg} / \mathrm{kg} /$ dia por $5-7$ meses seguida por $0.5 \mathrm{mg} / \mathrm{kg} / \mathrm{dia}$ por mais 3 meses) pode ser uma terapia eficaz para essa condição, apesar de recidivas serem comuns. Infelizmente, a isotretinoína nem sempre é eficaz (Otberg et al., 2008).

Antibióticos tópicos e orais para o tratamento da FA incluem tetraciclina, minociclina, eritromicina, cefalosporina e clindamicina. Outras opções terapêuticas incluem corticosteróides intralesionais, sulfato de zinco, dapsona e colchicina diariamente (Otberg et al., 2008).

Procedimentos cirúrgicos devem ser considerados na falha do tratamento medicamentoso ou se as lesões forem muito sintomáticas. Epilação com LASER de pulso longo, tipo Q switched rubi e laser de diodo 800nm tem tido bons resultados. O tratamento com moderna radioterapia externa também tem sido reportados. Incisão e drenagem de nódulos dolorosos, marsupialização com curetagem da parede do cisto, e extirpação total do couro cabeludo com enxerto de pele, têm sido relatados, mas devem ser os últimos recursos para os casos extremos e terapeuticamente refratários (Otberg et al., 2008). 


\subsection{Alopecias cicatriciais primárias mistas}

\subsubsection{Acne/ Foliculite Queloidiana (FQ)}

O termo acne queloidiana é impróprio já que não está associada com a acne vulgar, nem está presente em sua histologia colágeno queloidiano, e deve-se a sua aparência clínica (Somani e Bergfeld, 2008).

A foliculite queloidiana é uma foliculite crônica, idiopática e inflamatória que cursa com perda de cabelo e cicatrização hipertrófica com pápulas e placas, afetando

o couro cabeludo da nuca. É encontrada mais freqüentemente em negros do sexo masculino após a puberdade (14- 25 anos), e ocasionalmente mulheres negras e é ao menos dez vezes mais comum em negros do que em brancos, compreendendo cerca de $0,5 \%$ de todas as doenças dermatológicas na população negra. Entretanto, essa desordem pode ocorrer em homens brancos e, em raras ocasiões, em mulheres brancas (Sperling, 2008).

A causa da foliculite queloidiana permanece indeterminada. Uma propriedade única da unidade pilossebácea relacionada com a raça, haste do cabelo, ou pele do couro cabeludo tem sido usada para propor a base da evolução da doença. Alguns precipitantes da doença propostos incluem trauma mecânico da gola da camisa, escoriações e seborréia, infecção pelo Demodex ou por bactérias e auto-imunidade. Existe ainda um caso notificado em homem branco tratado com carbamazepina e difenilhidantoina juntas e outro caso tratado com a ciclosporina que desenvolveram a doença. Acne mecânica por capacetes, comprimento do cabelo, e pêlos 'encravados' 
(pseudofoliculite da nuca) são argumentos em grade parte desaprovados (Ross et al., 2005).

A foliculite queloidiana inicia-se com pápulas foliculares pequenas, planas e firmes cor de carne fresca ou marrom-avermelhado. As pápulas podem ser crostosas, umbilicadas, ou pustulares e podem conter cabelo. Os pacientes podem queixar-se de prurido e queimação. Em alguns indivíduos, estas pápulas se aglutinam para formar nódulos ou placas queloidianas amplas que podem ser desfigurantes. Pústulas, abscessos, fístulas, politriquia, foliculite em tufos, mau cheiro, exudação e dor são características incomuns deste tipo de doença. Em casos raros formam-se tumores grandes escleróticos que podem afetar significativamente a vida diária (Ross et al., 2005).

A histologia mostra folículos interrompidos com inflamação granulomatosa aguda e / ou crônica associada à cicatriz hipertrófica. O achado histopatológico precoce é um infiltrado neutrofílico ou linfoplasmocitário perifolicular e intrafolicular no istmo e infundíbulo inferior e, em particular em torno das glândulas sebáceas, que são perdidas no início da doença. Semelhante ao que ocorre na FD e na FA o infundíbulo está dilatado. A parede folicular "fragilizada" pelo processo inflamatório induz a uma reparação tipo fibroplasia lamelar concêntrica. Com os folículos destruídos, ocorre extrusão de fragmentos de pêlo na derme que são "engolidos" com consequente inflamação granulomatosa crônica e/ou formação de microabscessos. Nos estágios mais avançados, fibroplaisa folicular e interfolicular com cicatriz hipertrófica cutânea difusa, fístulas e inúmeros plasmócitos podem ser observados (Somani e Bergfeld, 2008). 
O tratamento é mais fácil e mais eficaz quando instituído durante a fase inicial (papulosa). A FQ representa frequientemente um desafio terapêutico para o dermatologista. A primeira linha de tratamento é a prevenção, evitar qualquer trauma e infecção é muito importante. Para casos leves, algum sucesso tem sido relatado com corticosteróides tópicos classe I ou II isoladamente ou em combinação com antibióticos tópicos. Acetonido de triancinolona intralesional mensal (10-40mg/dl) sozinho ou combinado com clindamicina 2\% tópica, ou antibiótico (tetraciclina) oral, crioterapia e terapia a LASER (dióxido de carbono, 1064nm Nd: YAG ou Diodo 810nm) também foram relatados no tratamento da FQ com algum sucesso. Para as placas extensas de FQ ou doença recalcitrante, a excisão cirúrgica pode ser necessária. Bons resultados foram obtidos quando os pacientes foram submetidos à excisão a frio incluindo a linha posterior do cabelo, extendendo-se a fáscia muscular ou tecido subcutâneo profundo. A intervenção cirúrgica deve ser reservada para os casos terapeuticamente refratários, extensos e sintomáticos (Otberg et al., 2008).

\subsubsection{Acne necrotica (varioliforme).}

Acne necrótica em adultos apresenta-se como uma desordem rara, crônica e recidivante. É caracterizada por pápulas pruriginosas ou dolorosas com umbilicação e necrose central, cujas crostas aderentes hemorrágicas, que se separam deixam cicatrizes varioliformes. As cicatrizes resultantes do processo têm aspecto perfurado, e são deprimidas, aparecendo como áreas focais de alopecia cicatricial com presença 
de cabelos terminais impactados. Acomete comumente o couro cabeludo parietal e anterior, mas regiões seborréicas da face, pescoço e peito também pode ser afetados. Com a cronicidade, cicatrizes cribiformes podem desenvolver e serem desfigurantes. O agravo da doença no verão tem sido reportado (Ross et al.,2005).

As causas e propostas incluem a resposta do hospedeiro anormal ao S. aureus ou ao Propioniobacterium acnes, escoriação neurótica de uma foliculite e uma gênese do tipo rosácea. A literatura mais antiga enfatiza a coexistência com a dermatite seborréica (Ross et al.,2005).

A principal característica histológica da acne necrotica é a foliculite supurativa, necrótica, com inflamação lifocítica infundibular precoce e infiltrado misto no desenvolvimento da doença (Otberg et al., 2008).

O tratamento inclui antibióticos por via oral, isotretinoína e corticosteróides intralesionais ou tópicos (Otberg et al., 2008).

\subsubsection{Dermatose Pustular Erosiva.}

A dermatose pustular erosiva é uma desordem rara, crônica e recidivante com formação de pústulas estéreis do escalpo resultando em alopecia cicatricial. Que acomete predominantemente mulheres idosas. Em alguns casos, pode ocorrer após trauma físico. A lesão característica é a formação de uma placa supurativa, necrótica com crostas superficiais que pode ser colonizada por estafilococos e Candida (Ross et al.,2005). 
Não existem características patológicas específicas da dermatose pustular erosiva nos primeiros estágios de progressão da doença. Um infiltrado crônico extenso constituído por células inflamatórias mistas, penetra na derme e na fase final, as unidades pilossebáceas são destruídas resultando em fibrose dérmica (Ross et al.,2005).

O tratamento da dermatose pustular erosiva inclui corticosteróides tópicos potentes e em associação com antibióticos tópicos. O uso de antibióticos orais e isotretinoína oral também têm sido relatados (Otberg et al., 2008).

\subsection{Alopecia Cicatricial Primária Inespecífica}

Alopecia cicatricial primária inespecífica é definida como uma alopecia cicatricial idiopática com resultados clínicos e histopatológicos inconclusivos que pode incluir-se na fase final de uma variedade de processos inflamatórios de alopecias cicatriciais primárias (Olsen et al., 2003). 
4 Casuística e Métodos 
Foi realizado estudo retrospectivo de prontuários e preparados histológicos pertencentes a 37 pacientes ambulatório de Dermatologia do Hospital de Clinicas da Faculdade de Medicina da Universidade de São Paulo (HC-FMUSP) com diagnostico histopatológica de alopecia cicatricial do couro cabeludo no período de 2000 a 2005.

- Critérios de inclusão:

Diagnóstico histopatológico de alopecia cicatricial primária, em fase tardia, pauci ou não-inflamatória.

- Criterios de exclusão

Diagnóstico histológico de alopecia cicatricial tardia tipo secundária

Os dados coletados dos prontuários incluíram sexo, raça, idade de início da doença e diagnóstico clínico e histopatológico prévio.

Os preparados histológicos revistos tinham sido obtidos por biópsia do couro cabeludo de pacientes com diagnostico clínico de alopecia, utilizando-se punch de 4 mm. Os fragmentos assim obtidos era inicialmente fixados em formol a 10\%, a seguir bisseccionados longitudinalmente e processados no laboratório de dermatopatologia da divisão de dermatologia do HC-FMUSP, segundo técnicas de rotina para inclusão em parafina e coloração pela hematoxilina e eosina, pelo PAS e pela resorcina-fucsina de Weigert com oxidação prévia pelo ácido peracético (CuzziMaia,2001). 
A revisão dos preparados histológicos foi realizada por dermatopatologista do Laboratório de Dermatopatologia da Divisão de Dermatologia do HC-FMUSP e pela autora da tese, de modo cego, e anotando a presença ou ausência de critérios histológicos coletados da literatura (Ross et al.,2005; Sellheyer e Bergfeld, 2006) e demonstrados no Quadro 2., a qual mostra também o desempenho habitual desses critérios nas principais alopecias cicatriciais.

Quadro 2. Parâmetros histológico utilizados na classificação das alopecias cicatriciais

\begin{tabular}{|c|c|c|c|c|c|}
\hline & LPP & LED & PB & FD & FA \\
\hline Hiperortoqueratose & - & + & - & $+/-$ & $+/-$ \\
\hline Rolha córnea & + folicular & + & - & $+/-$ & $+/-$ \\
\hline Atrofia epidérmica & - & + & - & $+/-$ & $+/-$ \\
\hline $\begin{array}{c}\text { Degeneração } \\
\text { vacuolar das } \\
\text { células basais da } \\
\text { epiderme. }\end{array}$ & - & + & - & $+/-$ & $+/-$ \\
\hline $\begin{array}{l}\text { Foliculite } \\
\text { neutrofílica }\end{array}$ & - & - & - & + & + \\
\hline $\begin{array}{l}\text { Perifoliculite } \\
\text { liquenóide }\end{array}$ & + & + & - & - & - \\
\hline $\begin{array}{c}\text { Infiltrado } \\
\text { linfocítico } \\
\text { periécrino }\end{array}$ & - & + & - & - & - \\
\hline Trato fibroso & $\begin{array}{c}+ \\
\text { com } \\
\text { corpos } \\
\text { colóides }\end{array}$ & + & + & + & + \\
\hline $\begin{array}{c}\text { Fibrose dérmica/ } \\
\text { hipodérmica } \\
\text { extensa }\end{array}$ & - & $+/-$ & - & + dérmico & $\begin{array}{c}\text { + dermo- } \\
\text { Hipodérmico }\end{array}$ \\
\hline Fístula & - & - & - & - & + \\
\hline
\end{tabular}




\begin{tabular}{|c|c|c|c|c|c|}
\hline $\begin{array}{c}\text { Manguito elástico } \\
\text { preservado. }\end{array}$ & - & - & + & - & - \\
\hline $\begin{array}{c}\text { Espessamento da } \\
\text { membrana basal da } \\
\text { epiderme }\end{array}$ & - & + & - & - & - \\
\hline
\end{tabular}

LPP: líquen plano pilar; LED: lupus eritematoso discoide; PB: pseudopelada de Brocq; FD: foliculite decalvante; FA: foliculite abscedante 
5 Resultados 
Do período de 2000 a 2005, foram identificados e revistos 37 casos nos quais a diagnose histopatológica final fora de alopecia cicatricial primária. Os laudos do exame histopatológico destes casos haviam sido condizentes com o diagnóstico de lúpus eritematoso discoide em 09 casos, líquen plano pilar em 02 casos, pseudopelada de Brocq em 11 casos, foliculite decalvante em 02 casos e 13 casos considerados como alopecia cicatricial não-específica.

Os casos foram então reclassificados, baseando-se nos critérios histológicos préestabelecidos, o que resultou no diagnóstico de 36 casos de alopecia cicatricial primária, mantendo-se apenas um caso como não-específico (Quadro 3.).

Quadro 3. Comparação dos diagnósticos prévios e após a revisão, de acordo com os parâmetros histológicos pré-estabelecidos

\begin{tabular}{|c|c|c|c|c|c|c|c|c|c|c|c|c|c|c|}
\hline $\begin{array}{l}\text { Casos/ } \\
\text { achados } \\
\text { histológicos }\end{array}$ & $\mathrm{HO}$ & $\mathrm{RC}$ & $\mathrm{AE}$ & DV & FN & PL & ILP & $\mathrm{TF}$ & FD & $\mathrm{F}$ & MEP & EMB & PRÉ & PÓS \\
\hline $\mathrm{C} 1 / 00$ & - & - & - & - & - & - & - & + & - & - & + & - & PB & PB \\
\hline $\mathrm{C} 2 / 00$ & + & + & + & + & - & - & + & + & + & - & - & + & LED & LED \\
\hline $\mathrm{C} 3 / 00$ & - & - & - & - & - & - & - & + & - & - & + & - & PB & PB \\
\hline $\mathrm{C} 4 / 00$ & + & + & + & + & + & - & - & + & $\begin{array}{l}+ \\
\text { dérmico }\end{array}$ & - & - & - & LED & FD \\
\hline $\mathrm{C} 5 / 00$ & + & + & + & - & - & - & + & + & $+/-$ & - & - & - & $\mathrm{NE}$ & LED \\
\hline C6/00 & + & + & + & + & + & - & - & + & $\begin{array}{l}+ \\
\text { dérmico }\end{array}$ & - & - & - & FD & FD \\
\hline $\mathrm{C} 7 / 00$ & + & + & + & + & - & - & + & + & $+/-$ & - & - & - & $\mathrm{NE}$ & LED \\
\hline $\mathrm{C} 8 / 00$ & + & + & + & + & - & - & + & + & - & - & - & + & $\mathrm{NE}$ & LED \\
\hline C9/01 & - & - & - & - & - & - & - & + & - & - & + & - & $\mathrm{PB}$ & $\mathrm{PB}$ \\
\hline $\mathrm{C} 10 / 01$ & - & - & - & - & - & - & - & + & - & - & + & - & $\mathrm{PB}$ & $\mathrm{PB}$ \\
\hline C11/01 & - & - & - & - & - & - & - & + & - & - & + & - & $\mathrm{NE}$ & PB \\
\hline C12/01 & + & + & - & - & - & + & - & + & - & - & - & - & FD & LPP \\
\hline $\mathrm{C} 13 / 02$ & + & + & + & + & - & - & + & + & + & - & - & - & LED & LED \\
\hline $\mathrm{C} 14 / 02$ & + & + & + & + & - & - & + & + & + & - & - & + & LED & LED \\
\hline $\mathrm{C} 15 / 02$ & - & $\begin{array}{l}+ \\
\text { folicular }\end{array}$ & - & - & - & + & - & $\begin{array}{l}+ \\
\text { corpos } \\
\text { coloides }\end{array}$ & - & - & - & - & LPP & LPP \\
\hline $\mathrm{C} 16 / 02$ & + & + & + & + & - & - & + & + & + & - & - & + & LED & LED \\
\hline $\mathrm{C} 17 / 02$ & - & - & - & - & - & - & - & + & - & - & + & - & $\mathrm{NE}$ & PB \\
\hline $\mathrm{C} 18 / 02$ & + & + & + & + & - & - & + & + & + & - & - & - & LED & LED \\
\hline C19/03 & + & + & + & + & - & + & + & + & - & - & - & + & $\mathrm{NE}$ & LED \\
\hline C20/03 & - & - & - & - & - & - & - & + & - & - & + & - & $\mathrm{NE}$ & $\mathrm{PB}$ \\
\hline $\mathrm{C} 21 / 03$ & - & - & - & - & - & - & - & + & - & - & + & - & PB & PB \\
\hline
\end{tabular}




\begin{tabular}{|l|l|l|l|l|l|l|l|l|l|l|l|l|l|l|}
\hline $\mathrm{C} 22 / 03$ & - & - & - & - & - & - & - & + & - & - & + & - & PB & PB \\
\hline $\mathrm{C} 23 / 03$ & + & + & + & + & - & - & + & + & + & - & - & + & LED & LED \\
\hline $\mathrm{C} 24 / 03$ & + & + & + & - & - & - & + & + & $+/-$ & - & - & + & NE & LED \\
\hline $\mathrm{C} 25 / 03$ & + & + & + & + & - & - & + & + & + & - & - & - & LED & LED \\
\hline $\mathrm{C} 26 / 03$ & - & - & - & - & + & - & - & + & + & - & - & - & PB & FD \\
\hline $\mathrm{C} 27 / 03$ & - & - & - & - & - & - & - & + & - & - & + & - & PB & PB \\
\hline $\mathrm{C} 28 / 03$ & + & + & + & - & - & - & + & + & - & - & - & + & NE & LED \\
\hline $\mathrm{C} 29 / 03$ & + & + & - & + & - & - & + & + & $+/-$ & - & - & + & NE & LED \\
\hline $\mathrm{C} 30 / 03$ & - & - & - & - & - & - & - & + & - & - & + & - & PB & PB \\
\hline $\mathrm{C} 31 / 03$ & + & + & + & - & - & - & - & + & - & - & - & - & PB & LED \\
\hline $\mathrm{C} 32 / 04$ & - & + & - & - & - & + & - & + & - & - & - & - & LPP & LPP \\
& & & & & & & & $\begin{array}{l}\text { corpos } \\
\text { coloides }\end{array}$ & & - & & & & \\
\hline $\mathrm{C} 33 / 05$ & - & - & - & - & - & - & - & + & - & - & - & - & NE & NE \\
\hline $\mathrm{C} 34 / 05$ & - & + & - & - & - & + & - & + & - & - & - & - & NE & LPP \\
\hline $\mathrm{C} 35 / 05$ & - & - & - & - & + & - & - & + & + dermo & & & + & NE & FA \\
\hline $\mathrm{C} 36 / 05$ & - & - & - & - & - & - & - & + & - & - & + & - & PB & PB \\
\hline $\mathrm{C} 37 / 05$ & + & + & + & + & - & - & + & + & + & - & - & - & LED & LED \\
\hline
\end{tabular}

HO: hiperortoqueratose; RO: rolha córnea; AE: atrofia epidérmica; DV: degeneração vacuolar das células basais da epiderme; FN: foliculite neutrofílica; PL: perifoliculite liquenóide; ILP: infiltrado linfocítico peri-écrino;TF: trato fibroso; FD: fibrose dermo-hipodérmica folicular extensa; F: fístula; MEP: manguito elástico preservado; EMB: espessamento da membrana basal da epidérmica; PRÉ: diagnóstico prévio a revisão histológica ; PÓS: diagnóstico após a revisão histológica; NE: não especifica; LPP: líquen plano pilar;LED: lupus eritematoso discoide; PB:pseudopelada de Brocq; FD: foliculite decalvante; FA: foliculite abscedante

Os dados obtidos foram divididos em grupos de acordo com o diagnostico histológico encontrado, conforme se segue:

Lupus Eritematoso Discoide: foi diagnosticado em 16 casos, representando 43,24\% do número total de alopecias cicatriciais. A relação feminino-masculino foi de 4,8: 1 (13 femininos e 3 masculinos). A idade variou de 29 a 75 anos, com uma idade média de 46,5 anos. Os achados histopatológicos incluíram hiperqueratose, presença de rolha córnea, atrofia da camada malpighiana, degeneração vacuolar da camada basal da epiderme e presença de trato fibroso substituindo os folículos. Membrana basal da epiderme espessada foi observada em $62,5 \%$ dos casos. $\mathrm{Na}$ coloração de Weigert, o manguito elástico estava parcialmente destruído ao redor do trato fibroso e havia focos de elastólise nas áreas de derme interfolicular em todos os 
casos revisados. A imunofluorescência direta resultou positiva em 03 de 13 casos onde foi realizada, com presença de $\operatorname{IgG}$ ao longo da junção dermo-epidérmica. (Figura 1.)

Pseudopelada de Brocq: foi diagnosticada em 12 casos, isto representou 32, 43 \% do número total das biópsias. A relação feminino-masculino foi 10:2. A idade de início da doença variou de 23 a 69 anos, com idade média de 54,4 anos. Os resultados histopatológicos característicos eram a ausência dos critérios vistos no LED e no LPP, e a preservação do manguito elástico ao redor do folículo. A imunofluorescência direta foi realizada em 02 casos, com presença de $\operatorname{IgM}$ na zona de membrana basal em ambos os casos.(Figura 2.).

Liquen Plano Pilar: Esta categoria de alopecia cicatricial representou 10,81\% do número total de biópsias, totalizando 04 casos. A relação feminino-masculino foi 2:2. As idades de início foram 21, 25, 28 e 48 anos. Em um caso ainda havia uma perifoliculite liquenóide no segmento do ístmo folicular, além dos tratos fibrosos. Nos outros casos, a revisão mostrou ausência de inflamação, perda do epitélio sebáceo, atrofia da área do "bulge" resultando em uma figura de ampulheta, e área fibrótica substituindo os folículos, com ou sem a presença de corpos colóides. A membrana basal não se apresentou espessada ao PAS, e no Weigert, o manguito elástico perifolicular estava parcialmente destruído. A imunofluorescência direta resultou positiva em um caso, revelando a presença de corpos citóides com presenca de IgM no epitélio folicular. (Figura 3.).

Foliculite Decalvante: foi diagnosticada em 03 casos, representando 8,10\% do número total de biópsias. A relação feminino-masculino foi 1:2. As idades de início de doença foram 17, 29 e 36 anos. Os achados histopatológicos foram a presença de 
foliculite supurativa e fibrose substituindo o folículo além de extensa elástolise perifolicular e distante dos folículos na coloração de Weigert.(Figura 4.).

Foliculite Abscedante/Dissecante: Esta categoria de alopecia cicatricial representou $2,70 \%$ do número total de biópsias totalizando 01 caso, representado por uma doente do sexo feminino com idade de início da doença de 19 anos. Neste caso a inflamação era leve e uma fibrose dérmica mais extensa e profunda se estendia até a hipoderme com presença de elastólise. (Figura 5.).

Alopecias Não Específicas: classificamos um de nossos casos como nãoespecífico porque exceto a destruição dos folículos, nenhum outro achado apontou uma diagnose mais específica. Tratava-se de um paciente do sexo feminino de 54 anos de idade.

Em nosso estudo, o uso do método descrito, permitiu a conclusão em 12 casos $(92,3 \%)$, inicialmente considerados como alopecia cicatricial não-específica ou idiopática.

Os pacientes não foram avaliados em relação ao tipo e a duração do tratamento devido se tratar de um estudo retrospectivo, sem protocolo terapêutico préestabelecido; e também e principalmente por esta analise não corresponder ao objetivo principal deste trabalho que se trata de uma classificação retrospectiva das alopecias cicatriciais primárias em uma fase tardia, pauci ou não inflamatória baseada em critérios histológicos. 

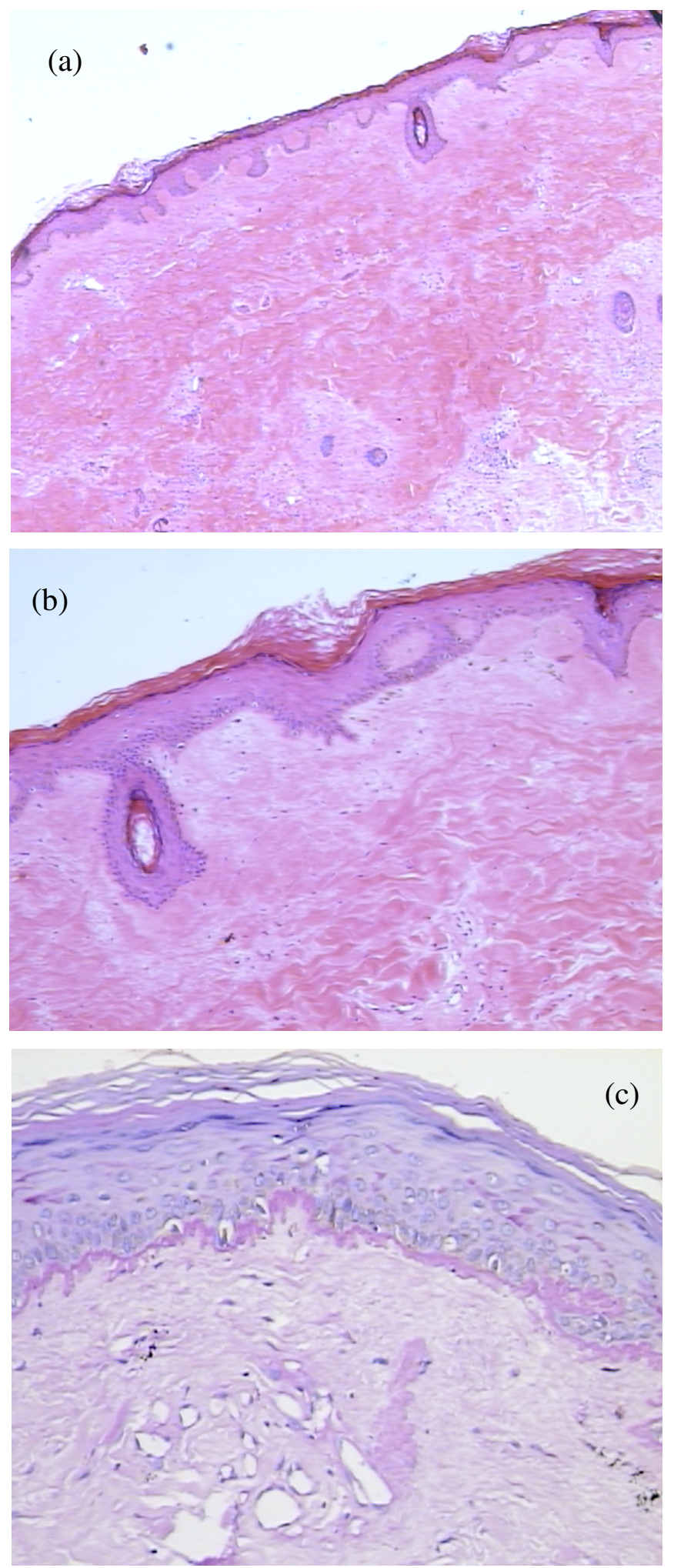

Figura 1. Alopecias cicatriciais linfocíticas em fase tardia: Lúpus eritematoso: (a) alopecia cicatricial com esclerose dérmica do colágeno; (b) - hiperqueratose com rolhas córneas e atrofia epidérmica; (c) - mesmo em fase tardia há espessamento da membrana basal. HE (a,b,); PAS (c); Aumento original: x40 (a,); x100 (b, c,). 

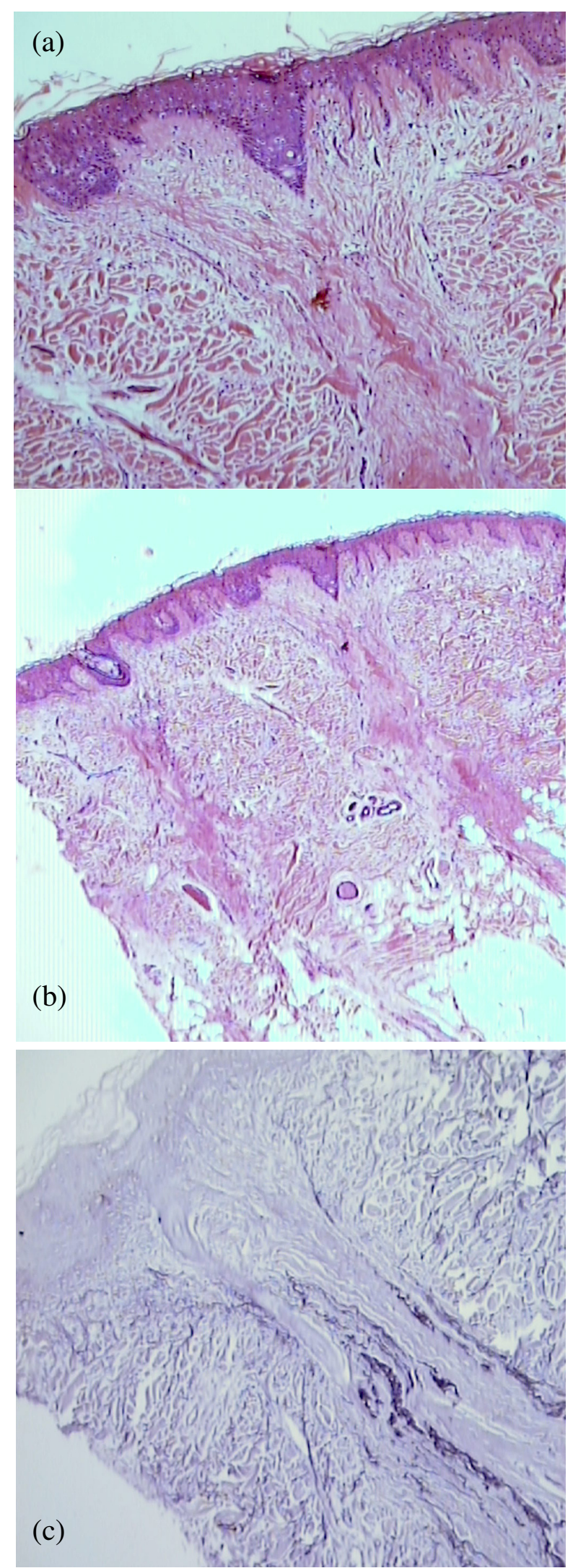

Figura 2. Alopecias cicatriciais linfocíticas em fase tardia: Pseudopelada de Brocq: (a) - alopecia cicatricial; (b) - ausência de critérios para lúpus e líquen; (c) manguito elástico perifolicular preservado HE (a,b); Weigert (c) Aumento original: x40 (a); x100 (b); x200 (c). 

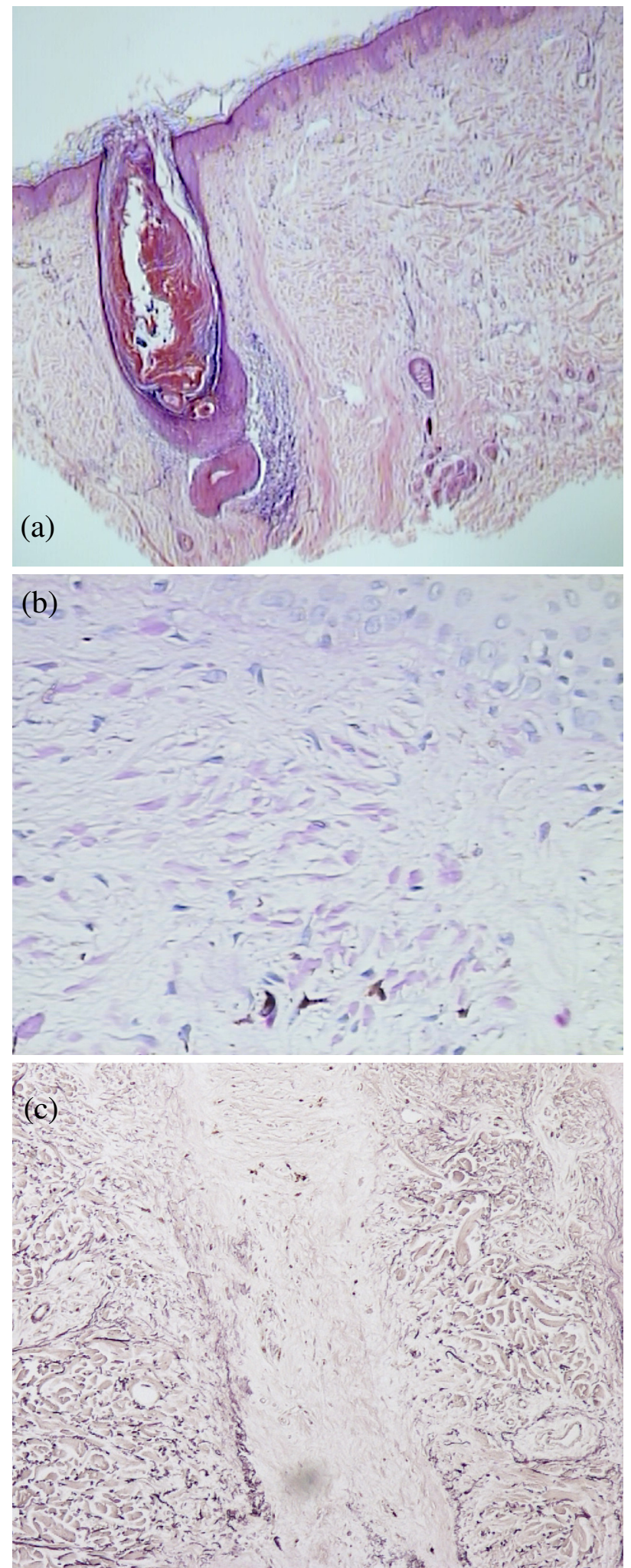

Figura 3. Alopecias cicatriciais linfocíticas em fase tardia: Líquen plano pilar: (a) trato fibroso, infiltrado liquenóide perifolicular e ausência de outras alterações dermo-epidérmicas; (b) - numerosos corpos colóides dentro do trato fibroso; (c) manguito elástico perifolicular parcialmente destruído. HE (a); PAS (b); Weigert (c) Aumento original: x40 (a); x100 (c); x400 (b). 

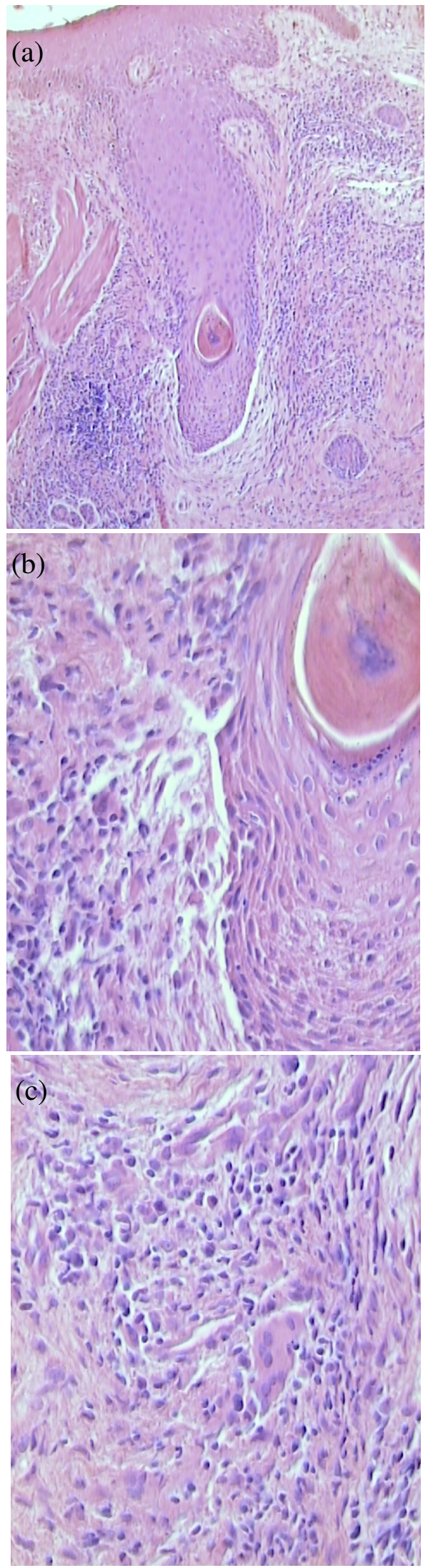

Figura 4. Alopecias cicatriciais neutrofílicas em fase tardia: Foliculite decalvante; (a) - foliculite neutrofílica com intensa perifoliculite; (b) - neutrófilos degenerados dentro do infundíbulo e infiltrado inflamatório perifolicular misto; (c) - alguns histiócitos multinucleados e plasmócitos; HE (a,b,c,). Aumento original: 100x (a); 400x (b,c). 

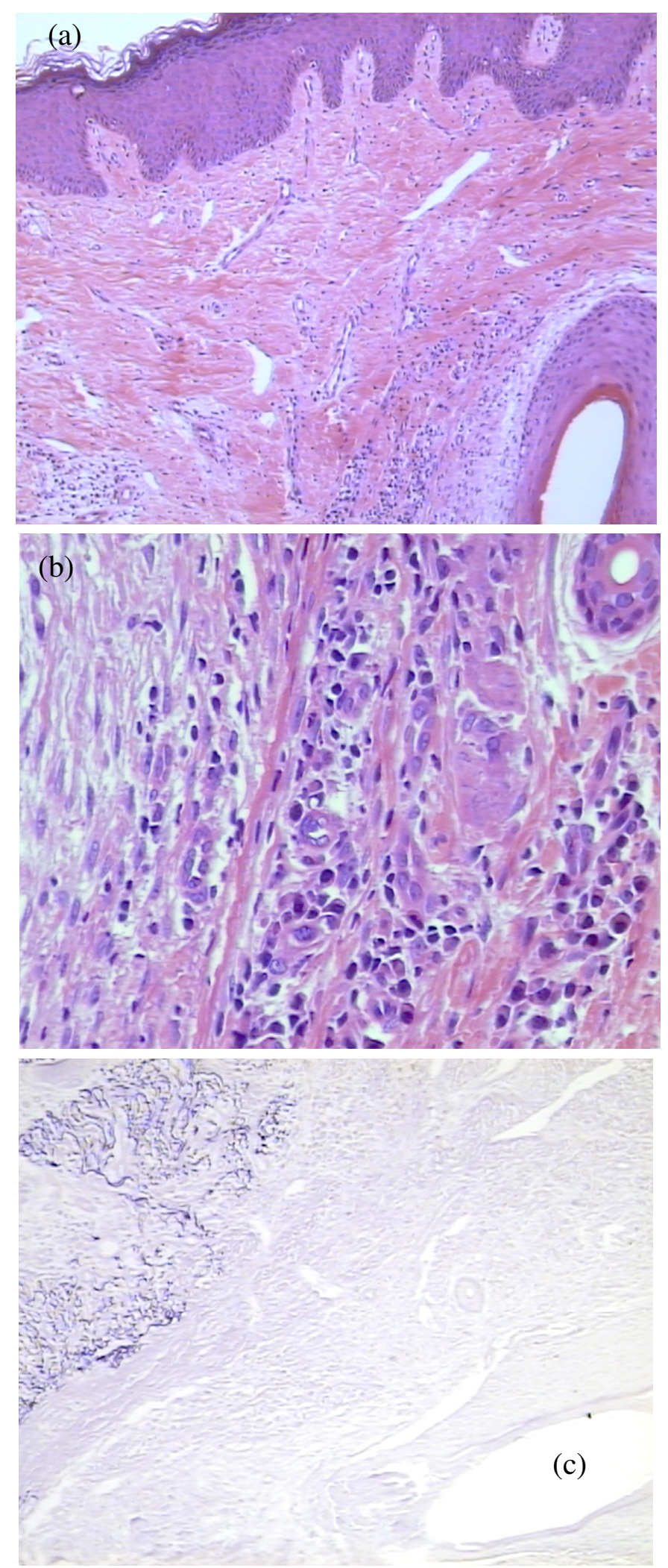

Figura 5. Alopecias cicatriciais neutrofílicas em fase tardia: Foliculite abscedante; (a) - fibrose cicatricial perifolicular e distante dos folículos, extensa e perifoliculite; (b) - infiltrado inflamatório plasmocitário; (c) - elastólise próxima e distante dos folículos. HE (a,b); Weigert (c). Aumento original: 100x (a,c); 400x (b). 
De acordo com o nosso quadro padrão, com critérios histológicos préestabelecidos, os casos foram classificados em Lupus Eritematoso Discoide, Liquen Plano Pilar, Pseudopelada de Brocq, Foliculte Decalvante e Foliculite Abscedante. Conforme os critérios propostos na nossa revisão, não foram observados achados que permitissem a classificação nos demais tipos de alopecias cicatriciais primárias, por isso manteremos nossa tabela e nossa discussão apenas com os tipos de alopecias cicatriciais primárias encontradas.

Em relação ao LPP deve-se considerar a possibilidades de se tratar também de uma de suas variantes (Alopecia frontal fibrosante /Sindrome de Graham-Little), necessitando de critérios clínicos adicionais para uma melhor classificaçao.

A acne queloideana não foi observada em nossa revisão, já que em nosso laboratório, essa afecção não é referida como alopecia cicatricial e sim como foliculite supurativa e/ou granulomatosa gigantocelular, com fibrose, consistente com o diagnóstico clínico, facilmente realizado, de foliculite queloideana da nuca.

Em relação ao tipo inflamatório predominante, nossa revisão encontrou uma razão de 8:1 entre alopecias cicatriciais linfociticas e neutrofilicas.

\subsection{Epidemiologia:}

- Distribuição dos doentes de acordo com o sexo:

Total de doentes estudados: $(n=37)$

Homens: $09(24,32 \%)$

Mulheres: $28(75,67 \%)$ 
Gráfico 1. Distribuiçao das alopecias cicatriciais primárias de acordo com o sexo.

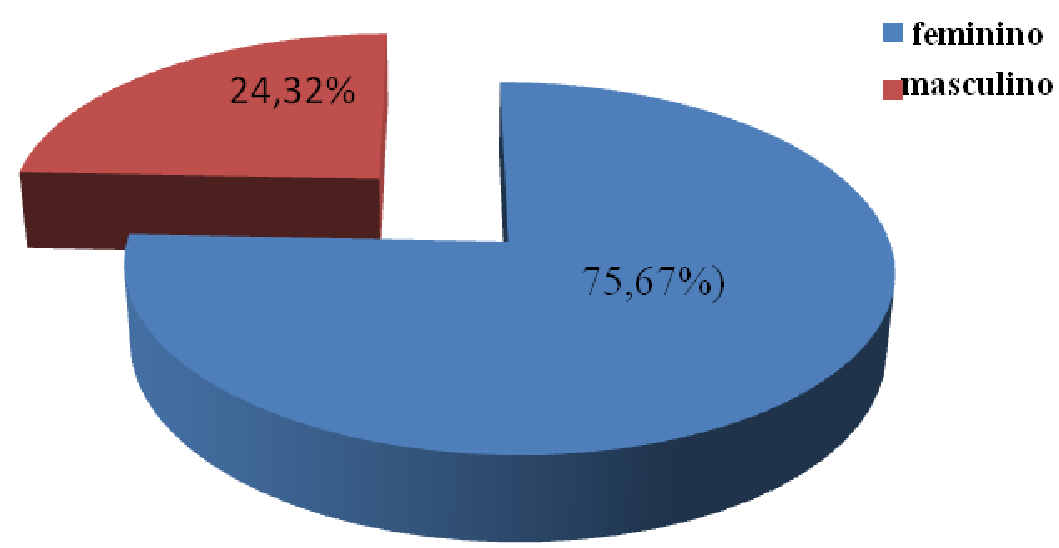

- Distribuição dos doentes conforme a cor:

Todos os doentes estudados foram descritos na avaliação clinica como sendo pardos.

Cor $(n=37)$

Parda $37(100 \%)$

- Idade média dos doentes: 44,77 anos

- Distribuição das alopecias cicatriciais primárias de acordo com as doenças:

Lupus Eritematoso Discóide: 16 (43,44\%)

Pseudopelada de Brocq: $12(32,43 \%)$

Líquen Plano Pilar: 04 (10,81\%)

Foliculite Decalvante: $03(8,10 \%)$

Foliculite Abscedante: 01 (2,70\%) 
Forma não específica: $01(2,70 \%)$

Grafico 2. Distribuição das alopecias cicatriciais primárias, de acordo com as doenças.

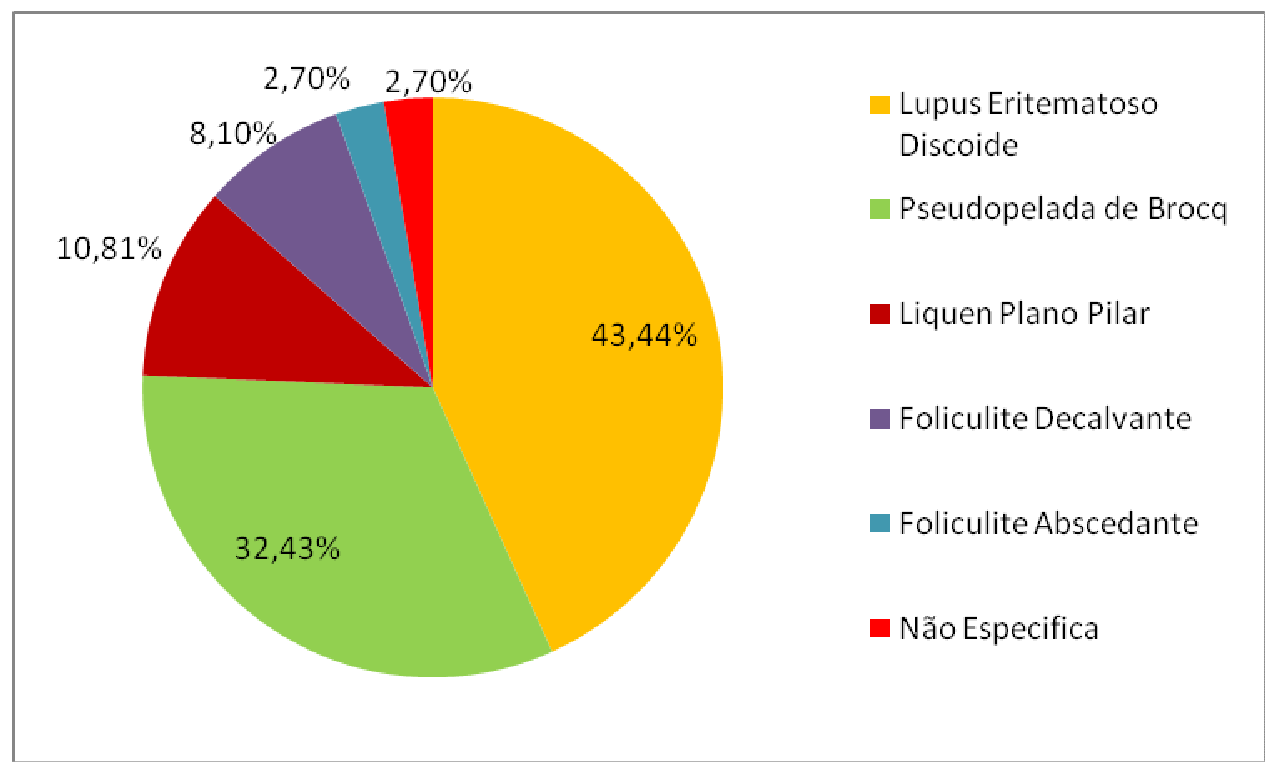


6 Discussão 
Em relação às alopecias cicatriciais podemos dizer que se tratam de entidades complexas e pobremente estudadas e entendidas. Quanto a sua patogênese não sabemos se o infiltrado inflamatório é realmente a principal causa da alopecia. É possível que defeitos ocorram primariamente nos folículos pilosos e que a inflamação seja inteiramente secundária ao início da doença (McElwee, 2010).

Embora a hipótese da existência de mecanismos auto-imunes envolvendo a gênese das alopecias cicatriciais, não há atualmente nenhuma evidência que apóie essa visão. Por outro lado, a aparente associação de agentes patogênicos com o início da alopecia cicatricial, como o $S$. aureus na alopecia mucinosa e na foliculite decalvante, sugere, que em algumas formas de alopecia cicatricial, antígenos exógenos possam ser o evento de ativação dominante e que mesmo dentro de cada categoria de diagnóstico clínico, possam existir diferentes agentes que incitem à doença (McElwee, 2010).

A classificaçao histológica das alopecias também é alvo de controvérsias, na literatura. Segundo Sperling e Cowper (2006) a classificação da maioria das formas de alopecias cicatriciais primárias, pode ser confusa e polêmica, devido à sobreposição de características clínicas e histológicas das doenças. De acordo com estes autores, por ser desconhecida a maioria das causas das alopecias cicatriciais, qualquer sistema de classificação deve ser considerado provisório até que novas informações estejam disponíveis.

Focaremos nossa discussão a respeito das alopecias de acordo com o que foi proposto pela sociedade norte-americana, a qual subdivide as alopecias cicatriciais primárias, baseada no tipo principal de infiltrado inflamatório. Uma abordagem que vem sendo utilizada em uma série de novos artigos (Sellheyer e Bergfeld, 2006; 
Otberg et al., 2008; Stefanato, 2010).

Em relação ao processo inflamatório podemos observar em nossa casuística um predomínio das alopecias cicatriciais primárias linfocíticas em relação às neutrofilicas (4:1), o que também foi relatado nos estudos feitos por Tan et al. (2004) e Whitining (2001).

Entre as alopecias linfocíticas o LED seguido pelo LPP foram as doenças mais freqüentemente encontradas assim como mostra o estudo realizado por Tan et al. (2004).

Nosso estudo mostrou um predomínio de alopecias cicatriciais primárias em mulheres e em relação à idade, a faixa etária foi maior nos pacientes com LED e PB que nas demais doenças. Embora a literatura mostre o LPP como tendo um início mais tardio na vida, três dos nossos quatro casos eram adulto-jovens. (Tan et al., 2004)

Considerando o grupo das alopecias cicatriciais primárias linfocíticas na fase inflamatória, o principal diagnóstico diferencial a ser considerado para o LED é o LPP. Porém no LED a alteração de interface é principalmente vacuolar ao invés de liquenóide (Sellheyer e Bergfeld, 2006). No LED o infiltrado perivascular superficial e profundo, o padrão periécrino de inflamação, a presença de mucina na derme, assim como presença de corpos citóides no epitélio ajudam na diferenciação com o LPP. Na IFD a presença de depósito granular denso de imunoglobulina IgG na junção dermo-epidérmica observado no LED complementa o diagnóstico (Ross et al., 2005; Somani e Bergfeld, 2008).

Nas fases pauci ou não-inflamatórias, como em nossos casos de LED, as principais alterações foram vistas na epiderme interfolicular mostrando 
hiperqueratose e atrofia, diferente do que acontece no LPP cujo processo inflamatório fica restrito a epiderme folicular. Em relação à derme no LPP a alteração geralmente observada é a presença de fibrose substituindo o folículo, enquanto no LED há fibrose extra-folicular e freqüente elastólise (Sellheyer e Bergfeld, 2006). Mesmo em uma fase tardia é possível observar ao PAS um espessamento da membrana basal da epiderme como o que ocorreu em $62,5 \%$ dos nossos casos de LED (Ross et al., 2005).

O LED pôde ser diferenciado da PB pela presença de alterações de interface vacuolar ao nível do infundíbulo folicular, na PB o processo inflamatório era mínimo ou ausente (Templeton e Solomon, 1994). Em nossos achados, a coloraçao para fibra elática permitiu confirmar a presença do manguito elástico conservado na $\mathrm{PB}$, diferentemente do que ocorreu no LED e no LPP em que o manguito encontrava-se parcialmente destruído, conforme o que havia sido descrito previamente por Pinkus (1978).

Atualmente, embora diferentes teorias existam sobre a verdadeira natureza da $\mathrm{PB}$, a dúvida é, se a mesma representa a fase final atrófica de vários distúrbios ou cicatrizes ou se ela representa realmente uma doença autônoma caracterizada por uma alopecia cicatricial idiopática (Amato et al., 2002).

Para Sellheyer e Bergfeld (2006) a teoria de que a PB seja o estágio final de outras formas de alopecia é equivocada, eles observaram que nos estudos que tentam provar que a PB não é uma entidade nosológica distinta, há uma falta de correlação sólida histopatológica. Desta forma, a característica marcante das fibras elásticas preservadas ao exame histológico justificaria a classificação da PB como uma forma de alopecia cicatricial primária e permanente. Eles acreditam que a correlação 
clinicopatologica e o uso da coloração convencional de hematoxilina-eosina acrescida das colorações específicas para fibra elástica são suficientes para diferenciar a PB das formas tardias de LED e LPP na maioria dos casos, justificando esta condição como uma entidade sui generis.

Em relação às alopecias cicatriciais neutrofílicas, é possível notar a semelhança histológica entre a FA e a FD, ambas com presença de infiltrado inflamatório mesmo na fase tardia, caracterizada pela presença de foliculite neutrofílica, profunda na primeira, e superficial na segunda, que permite a diagnose histopatológica. Podemos observar também que o processo fibrótico secundário a estas foliculites era mais intenso do que nas alopecias cicatriciais linfocíticas e era precedido por tecido de granulação, como é esperado que aconteça depois de um processo supurativo (Somani e Bergfeld, 2008).

Presença de fístulas é achado histopatológico característico da FA não observados na FD ou na acne queloideana (Somani e Bergfeld, 2008), porém fístulas não foram observadas em nosso trabalho provavelmente devido as casos estarem em uma fase tardia pauci-inflamatória.

A acne queloideana não esteve presente na nossa revisão, já que em nosso laboratório, essa afecção não é referida como alopecia cicatricial e sim como foliculite supurativa e/ou granulomatosa gigantocelular com fibrose.

Em relação às foliculites neutrofilicas, antes de qualquer diagnóstico histológico é necessária a exclusão de foliculites bacterianas e fúngicas através de colorações específicas (Somani e Bergfeld, 2008). 
7 Conclusão 
Frente os resultados obtidos, podemos concluir o que:

7.1, Nas amostras representando fases tardias, cicatriciais, pauci- ou nãoinflamatórias das alopecias cicatriciais primárias do couro cabeludo, a histopatologia com avaliação sistemática dos critérios microscópicos, permitiu diagnóstico nosológico em $12(92,3 \%)$ dos 13 dos casos, inicialmente considerados como alopecia cicatricial inespecífica pela microscopia.

7.2 A avaliação conjunta dos critérios histológicos pré-estabelecidos, através da coloração pela HE, PAS e resorcina-fucsina de Weigert, permitiram o diagnóstico de lúpus eritematoso dscóide em 16 doentes, de líquen plano pilar em 04 doentes, de foliculite decalvante em 03 doentes e de foliculite abscedante em 01 doente, assim como confirmou o diagnóstico de pseudopelada de Brocq em 12 doentes. As colorações específicas constituíram método diagnóstico importante na caracterização etiológica das alopecias cicatriciais.

7.3 Nem sempre são necessários métodos complexos ou de alto custo para auxilar no diagnóstico das alopecias cicatriciais primárias em fase adiantada. Muitas vezes, a análise histológica acurada associada à realização de colorações específicas é suficiente para a elucidação diagnóstica. 
ANEXO 1: APROVAÇÃO PELO CONSELHO DE ÉTICA

Andamento do Projeto hittp://portal2.saude.gov.br/sisnep/extrato_projeto.cfm?codigo $=256060$

\begin{tabular}{|c|c|c|c|c|c|c|c|}
\hline \multicolumn{8}{|c|}{ Título do Projeto de Pesquisa } \\
\hline \multicolumn{8}{|c|}{$\begin{array}{l}\text { Alopecias Cicatriciais: Uma revisão de dados clínico paipatológicos de prontuários de pacientes atendidos no ambulatório de dermatologia do } \\
\text { Hospital das Clínicas da Faculdade de Medicina da Universidade de São Paulo no período de 2000-2005. }\end{array}$} \\
\hline Situação & \multicolumn{2}{|c|}{ Data Inicial no CEP } & \multicolumn{2}{|c|}{ Data Final no CEP } & \multicolumn{2}{|c|}{ Data Inicial na CONEP Data } & na CONEP \\
\hline Aprovado no CEP & \multicolumn{2}{|c|}{ 08/05/2009 13:28:11 } & \multicolumn{2}{|c|}{$22 / 05 / 200907: 54: 28$} & & & \\
\hline \multicolumn{2}{|c|}{ Descrição } & \multicolumn{2}{|c|}{ Data } & \multicolumn{2}{|c|}{ Documento } & $\mathrm{N}^{\circ}$ do Doc & Origem \\
\hline \multicolumn{2}{|c|}{3 - Protocolo Aprovado no CEP } & \multicolumn{2}{|c|}{$22 / 05 / 200907: 54: 28$} & \multicolumn{2}{|c|}{ Folha de Rosto } & 0432/09 & CEP \\
\hline \multicolumn{2}{|c|}{1 - Envio da Folha de Rosto pela Internet } & \multicolumn{2}{|c|}{$15 / 04 / 2009$ 17:37:34 } & \multicolumn{2}{|c|}{ Folha de Rosto } & FR256060 & Pesquisador \\
\hline \multicolumn{2}{|c|}{2 - Recebimento de Protocolo pelo CEP (Check-List) } & \multicolumn{2}{|c|}{ 08/05/2009 13:28:11 } & \multicolumn{2}{|c|}{ Folha de Rosto } & 0410.0.015.000-09 & CEP \\
\hline
\end{tabular}




\title{
Primary cicatricial alopecias: a review of histopathologic findings in 38 patients from a clinical University Hospital in Sao Paulo, Brazil
}

\author{
Emanuella Rosyane Duarte Moure; Ricardo Romiti; Maria Cecília da \\ Matta Rivitti Machado; Neusa Yuriko Sakai Valente \\ Department of Dermatology, Hospital das Clínicas, Faculdade de Medicina, \\ Universidade de São Paulo - São Paulo/SP, Brazil. Email: \\ emanuellamoure@gmail.com Tel.: 55113564.0112
}

\begin{abstract}
BACKGROUND: Scarring alopecias are classified into primary and secondary types according to the initial site of inflammation. In primary scarring alopecias, the hair follicle is the main target of destruction; the term secondary cicatricial alopecia implies that follicular destruction is not the primary pathologic event. AIMS: To review the histopathologic diagnoses of cases of cicatricial alopecia in order to classify them according to the North American Hair Research Society. PATIENTS AND METHODS: Patients with biopsy specimens diagnosed as cicatricial alopecia seen from 2000 to 2005 at the Dermatologic Department of Hospital das Clinicas, São Paulo University Medical School had hematoxylin and eosin, Periodic acid-Schiff and Weigert stained slides reevaluated and sub-typed into different primary cicatricial alopecias. RESULTS: Thirty-eight cases of primary cicatricial alopecias were reclassified as: chronic cutaneous lupus (17), lichen planus pilaris (4), pseudopelade of Brocq (12), folliculitis decalvans (3), dissecting folliculitis (1), and non-specific scarring alopecia (1). In our cases, the methods employed allowed an accurate diagnosis in 12 of 13 cases $(92.3 \%)$ previously classified as non-specific cicatricial alopecias.

CONCLUSIONS: Even in the late, pauci or non-inflammatory phases, an approach with systematic evaluation of a constellation of criteria in routine hematoxylin and eosin stain, Periodic acid-Schiff and Weigert stain allowed for a more accurate diagnosis of cicatricial alopecias.
\end{abstract}

Keywords: Cutaneous lupus erythematosus; Lichen planus pilaris; Pseudopelade of Brocq; Folliculitis decalvans; Dissecting folliculitis.

\section{INTRODUCTION}


Alopecias can be broadly classified into non-scarring or non-cicatricial and scarring or cicatricial forms. Pathologically, a scar constitutes the end point of reparative fibrosis with permanent destruction of the preexisting tissue. ${ }^{1}$

Scarring alopecias are further subdivided into primary and secondary types. In primary scarring alopecias, the hair follicle is the primary target of destruction, which is microscopically evident as "preferential destruction of follicular epithelium and/or its associated advential dermis with relative sparing of the reticular dermis. ${ }^{2 "}$ This group includes the following clinical entities: chronic cutaneous lupus erythematosus (CCLE), lichen planopilaris (LPP), pseudopelade of Brocq (PB), folliculitis decalvans (FD), dissecting cellulitis/folliculitis (DF). If the follicular destruction is secondary to the scarring and occurs outside the follicular unit, e.g., the reticular dermis, epidermis, or sub cutis, it can eventually impinge upon and even eradicate the whole follicle. The term secondary scarring alopecia implies that follicular destruction is not the primary pathologic event. Exogenous factors, such as burns, and endogenous infiltrative and inflammatory diseases, such as sarcoidosis, pemphigus vulgaris and reticular dermal sclerosis, can result in secondary alopecias.

In 2001, a group of hair clinicians, pathologists and researchers, under the rubric of the North American Hair Research Society (NAHRS), ${ }^{3}$ issued a consensus opinion on the classification of primary cicatricial alopecias. The proposed classification subdivides primary scarring alopecias on the basis of the predominant type of inflammatory cell component, an approach that had already published ${ }^{1,4,5-7}$ and was further refined by the workshop. In addition to the lymphocyte- and neutrophil-associated subgroups, a mixed and nonspecific group was differentiated and newly defined (Table 1 ). 
Table1 - Primary Scarring (Permanent) Alopecias (according to the Proposed Working Classification of Primary Cicatricial Alopecia by the North American Hair Research Society; 1999) ${ }^{3}$

Lymphocyte-associated primary scarring alopecias

Chronic cutaneous lupus erythematosus

Lichen planopilaris

Classic lichen planopilaris

Frontal fibrosing alopecia

Graham Little syndrome

Classic pseudopelade (Brocq)

Central centrifugal cicatricial alopecia

Alopecia mucinosa

Keratosis follicularis spinulosa decalvans

Neutrophil-associated primary scarring alopecias

Folliculitis decalvans

Dissecting cellulitis/folliculitis (perifolliculitis abscedens et suffodiens)

Mixed inflammatory primary scarring alopecias

Folliculitis (acne) keloidalis

Folliculitis (acne) necrotica

Erosive pustular dermatosis

Nonspecific primary scarring alopecias ${ }^{\star}$

* Non-specific scarring primary alopecia is defined as an idiopathic scarring alopecia with inconclusive clinical and histopathologic findings and may include the end stage of a variety of inflammatory primary scarring alopecias, such as lichen planopilaris and folliculitis decalvans.

In the late phase of cicatricial alopecias, a histopathologic diagnosis is more difficult because the main criteria of classification, i.e., the type of inflammatory infiltrate, cannot always be evaluated. In these cases, additional criteria, such as the evaluation of the perifollicular elastic sheet and the fibrosis, can be useful.

The goal of this study was to review clinical and histopathologic findings of 38 patients diagnosed with late, pauci or non-inflammatory phase of cicatricial alopecias at the Dermatologic Department of the Hospital das Clinicas, São Paulo University Medical School, over a six-year period in order to classify them by sub-types according to NAHRS and evaluate the dermal elastic system and thickness of the epidermal basement membrane, using Weigert and PAS stains, respectively. 


\section{PATIENTS AND METHODS}

Biopsy specimens obtained using $5-\mathrm{mm}$ punches from patients seen between 2000 and 2005 at the Dermatologic Department of Hospital das Clinicas, São Paulo University Medical School with cicatricial alopecias in the late, pauci or non-inflammatory phase were reevaluted. Essential criteria included histopathologic diagnosis of cicatricial alopecia and accessibility of the patient's clinical records. Slides stained with hematoxylin and eosin, PAS and stain for elastic tissues (Weigert with previous oxidation by peracetic acid) were reviewed, evaluating the presence or absence of criteria listed in the Table 2 . This table shows the histopathologic criteria for different causes of cicatricial alopecia.

\section{RESULTS}

A total of 38 cases with a histopathologic diagnosis of cicatricial alopecia were included in the study. These cases had been previously diagnosed as follows: eight cases of CCLE, two cases of LPP, 13 cases of PB, two cases of FD, one case of scleroderma and 13 cases of non-specific cicatricial alopecia.

The cases were reclassified into primary or secondary alopecias. The ratio of primary versus secondary alopecias was $37: 1$. One case was classified as nonspecific alopecia. Twelve of 13 cases $(92.3 \%)$ that were initially classified as non-specific cicatricial alopecias could be specifically reclassified.

Chronic cutaneous lupus erythematosus was diagnosed in 17 cases, representing $43.6 \%$ of the total number of scarring alopecias. The female to male ratio was 4.7: 1 ( 14 females and three males). The age at onset ranged from 29 to 75 years, with a mean age of 46.5 years. Characteristic histopathologic findings of the late phase included hyperkeratosis, horn plugs, atrophy of the Malpighian layer, slight vacuolar degeneration of the basal layer, and fibrous tract replacing the follicles. A thickened basal membrane could be seen in $58.8 \%$ of the cases on PAS -stained sections, and an incomplete elastic sheet occurred around the fibrous tracts. in all cases on Weigert- stained sections. Elastolytic foci were also found in areas of fibrosis outside the perifollicular zone.

Lichen planus pilaris: This category of cicatricial alopecia represented $10.2 \%$ of the total number of biopsies, totaling four cases. The genders were equally represented. The ages at onset were $21,25,28$ and 48 years. In one case, there was a lichenoid infiltrate around the infundibuloisthmic segment of one follicle in addition to fibrous tracts replacing follicles. In all the others, absence of inflammation, absence of sebaceous epithelium, and atrophy of the bulge area occurred, resulting in hourglass figures. Fibrous tracts replacing the follicle, with or without the presence of colloid bodies, were also observed. The basal membrane was not thickened on PAS-stained sections, and the perifollicular elastic sheet was partially destroyed, as observed with the Weigert stain.

Pseudopelade of Brocq was diagnosed in 12 cases, representing $30.8 \%$ of the total number of biopsies. The female to male ratio was 10:2. Age of onset ranged from 23 to 69 years, with a mean age of 54.4 years. Characteristic histopathologic findings were the absence of criteria seen in CCLE and LPP and preservation of the elastic sheet around the follicles. 
Folliculitis decalvans was diagnosed in three cases, representing $7.7 \%$ of the total number of biopsies. The female to male ratio was $1: 2$. The age of onset was 17,29 and 36 years.

The histopathologic hallmark was the presence of superficial suppurative folliculitis and fibrosis replacing the follicle and the perifollicular area, with elastolysis visible with the Weigert stain.

Dissecting folliculitis: This category of cicatricial alopecia represented $2.6 \%$ of the total number of cicatrizing biopsies, totaling one case in a female 19 year-old patient. In this case, the inflammation was slight, and there was an extensive and deeper dermal fibrosis extending to the hypodermis, with elastolysis.

Idiopathic alopecias: One case of non-specific alopecia was diagnosed due to the destruction of the follicles being the only histopathologic finding. No additional criteria pointed to a more specific diagnosis.

\section{DISCUSSION}

Considering the group of primary lymphocytic cicatricial alopecias in the inflammatory phase, a differential diagnostic consideration for CCLE is LPP. However, the interface alteration is primarily vacuolar rather than lichenoid in CCLE. The superficial and deep perivascular and periecrine patterns of inflammation further aid in differentiating CCLE from LPP. In the late pauci or non-inflammatory phase, as observed in our cases of CCLE, interfollicular epidermis alterations were evident (hyperkeratosis and atrophy), in an area usually spared in LPP cases. Commonly, in the dermis in LPP, the only disturbance was the fibrous tract replacing the follicle, while in CCLE, there was frequent extra follicular fibrosis and elastolysis; even in this late phase, the basement membrane was thickened in $58.8 \%$ of cases. CCLE is differentiated from PB by the presence of predominately vacuolar interface changes at the level of follicular infundibulum in the former and lack of interface alterations in the latter. ${ }^{1}$ In our cases, the perifollicular elastic sheet was preserved in PB cases, while it was partially destroyed in LPP and CCLE, confirming the previous findings of Pinkus et al. ${ }^{7}$

Some authors believe that PB is not a distinct clinical-pathologic entity but a variant of certain primary cicatricial alopecias or, alternatively, a form of endstage alopecia caused by other scarring alopecias, such as CCLE, LPP and FD. ${ }^{7-9}$

According to Stephen $(1993)^{1}$ and other authors, with whom we agree, PB does indeed have sufficient distinct pathologic features to merit a separate classification..$^{5,10-12}$ Klaus and Wilma $(2006)^{1}$ believe that the close clinicopathlogic correlation in the histologic absence of significant follicular plugging, as well as the use of elastic fiber stain in addition to evaluation of conventional HE-stained sections, should enable the differentiation of classic PB from late stage lesions of LPP and CCLE in most cases and further justify the classification of the condition as an entity sui generis.

In relation to the neutrophilic cicatricial alopecias, it is remarkable that even in the late phases of this disorder, it seems that the inflammatory process persists 
in our cases, , and a neutrophilic folliculitis can frequently be seen, which helps make the correct histopathologic diagnosis. We could also see that the fibrotic process that is secondary to this neutrophilic folliculitis was more intense and proceeded by a granulation tissue, as is expected after a suppurative process. This fibrosis is deeper in DF than in FD. Sinus tracts are the histopathologic hallmark of dissecting cellulites and are not seen in either folliculitis decalvans or acne keloidalis and were not observed in our late phase cases. Bacterial or fungal folliculitis (kerion and favus) may have to be excluded in the group of neutrophilic cicatricial alopecias, with the use of special stains. Acne keloidalis cases were not seen in our series because they are histopathologically reported in our laboratory as a superficial and deep suppurative and giant cellular granulomatous folliculitis with extensive fibrosis compatible with acne keloidalis, not as a cicatricial alopecia. Besides, the clinical aspect of this disorder is so typical that histopathologic exam is seldom required.

\section{CONCLUSION}

A scalp biopsy is mandatory in all cases of cicatricial alopecias, representing the clinically inflammatory area. If there is no evidence of inflammation, a biopsy at the border of the cicatricial zone should be performed. Multiple biopsies are sometimes required to achieve a definitive diagnosis. A precise diagnosis is possible, even in the late, pauci or non-inflammatory phase of cicatricial alopecias if a systematic evaluation of a constellation of criteria is employed, using routine $\mathrm{HE}, \mathrm{PAS}$ and a stain for elastic tissue. In our cases, this method allowed a precise diagnosis in $97.4 \%$ of cases, even in those initially considered non-specific cicatricial alopecia.

\section{REFERENCES}

1. Sellheyer K and Bergfeld WF. Histopathologic Evaluation of Alopecias. Am J Dermatopathol. 2006;28:236-59.

2. Templeton SF, Solomon AR. Scarring alopecia: a classification based on microscopic criteria. J Cutan Pathol. 1994;21:97-109.

3. Olsen EA, Bergfeld WF, Cotsarelis G, Price VH, Shapiro J, Sinclair R, et al. Summary of North American Hair Research Society (NAHRS) - sponsored Workshop on Cicatricial Alopecia, Duke University Medical Center, February 10 and 11, 2001. J Am Acad Dermatol. 2003;48:103-10.

4. Trüeb RM. Vernarbende Alopezien: Diagnostik und Therapie. Schweiz Rundsch Med Prax. 1997;86:987-92.

5. Solomon AR. The transversely sectioned scalp biopsy specimen: the technique and an algorithm for its use in the diagnosis of alopecia. Adv. Dermatol. 1994; 9:127-57. 
6. Whiting DA. Cicatricial alopecia: clinico-pathological findings and treatment. Clin Dermatol. 2001;19:211-25.

7. Pinkus $\mathrm{H}$. Differential patterns of elastic fibers in scarring and non-scarring alopecias. J Cutan Pathol. 1978:5:93.

8. Anderton RL, Cullen SI. Pseudopelade of Brocq secondary to lichen planus. Cutis. 1976:17:916.

9. Sperling LC, Sau P. The follicular degeneration syndrome in black patients: "hot comb alopecia" revisited and revised. Arch Dermatol 1992:128:68.

10. Ronchese F. Pseudopelade. Arch Dermatol 1960:82:336.

11. Braun-Falco O, Imai S, Schmoeckel C, Steger O, Bergner T. Pseudopelade of Brocq. Dermatologica. 1986;172;18:23.

12. Pierard-Franchimont C, Pierard GE. Massive lymphocyte-mediated apoptosis during the early stage of pseudopelade. 1986:172:254.

Received for publication on July 4, 2008

Accepted for publication August 20, 2008

Moure ERD, Romiti R, Machado MCMR, Valente NYS. Primary cicatricial alopecias: a review of histopathologic findings in 38 patients from a clinical university hospital in São Paulo, Brazil. Clinics. 2008;63:747-52.

(cc) EY-No All the content of the journal, except where otherwise noted, is licensed under a Creative Commons License

Faculdade de Medicina / USP

Av. Ovídio Pires de Campos, 225 - 6 and.

05403-010 São Paulo SP - Brazil

Tel.: (55 11) 3069-6235 begin_of_the_skype_highlighting

(55 11) 3069-6235 end_of_the_skype_highlighting

efMail

editorial.office@hcnet.usp.br 
9 Referências 
1. Abraham LS, Moreira AM, Moura LH, Dias Gavazzoni. Tratamentos estéticos e cuidados dos cabelos: uma visão medica (parte 1). Surgical \& Cosmetic Dermatology. 2009; 1:3.

2. Ahmed B and Jaspan BJ. Hirsutism: a brief review. Am J Med Sci 1994 ; 308(5): 289-294.

3. Amato L, Mei S, Massi D, Gallerani I, Fabbri P. Cicatricial alopecia; a dermatopathologic and immunopathologic study of 33 patients (pseudopelade of Brocq is not a specific clinico-pathologic entity). Int J Dermatol. 2002 Jan;41(1):8-15.

4. Assouly P, Reygagne P. Lichen Planopilaris: Update on Diagnosis and treatment. Seminars in Cutaneous Medicine and Surgery 2006.

5. Bergfeld WF. Alopecia: histologic changes. Adv Dermatol.1989;4:301-322.

6. Boer A, Guo Y, Ackerman AB. Alopecia mucinosa is mycosis fungoides. Am J Dermatopathol. 2004;26(1):33-52.

7. Botchkarev VA, Botchkareva NV, Roth W, et al. Nogginis a mesenchymally derived stimulator of hair-follicle induction. Nat Cell Biol. 1999;1:158-64.

8. Bouillon C, Wilkinson J. The science of hair care. Taylor \& Francis. 2 ed. 2005.

9. Cannell DW. Permanent waving and hair straightening. Clin Dermatol 1988; 6(3): 71-82.

10. Chronnell CMT, Ghali LR, Ali RS, et al. Human b defensin-1 and -2 expression in human pilosebaceous units: upregulation in acne vulgaris lesions. J Invest Dermatol. 2001;117:1120-5. 
11. Chuong CM. Morphogenesis of epithelial appendages: variations on top of a common theme and implications in regeneration. In: Chuong CM (ed.). Molecular Basis of Epithelial Appendage Morphogenesis. Austin: RG Landes, 1998; 3-14.

12. Cotsarelis G, Kaur P, Dhouailly DD, et al. Epithelial stem cells in the skin: definition, markers, localization and functions. Exp Dermatol. 1999; 8:80

13. Cuzzi-Maia T, Piñeiro-Maceira J. Dermatologia - bases para o diagnóstico morfológico. São Paulo: Roca, 2001. p.2-11.

14. Douwes KE, Landthaler M, Szeimies RM. Simultaneous occurrence of folliculitis decalvans capillittii in identical twins. Br J Dermatol 2000; $143: 195-7$.

15. Eichmüller S, van der Veen C, Moll I, et al. Clusters of perifollicular macrophages in normal murine skin: physiological degeneration of selected hair follicles by programmed organ deletion. J Histochem Cytochem. 1998; $46: 361-70$.

16. Fabbri P, Amato L, Chiarini C, Moretti S, Massi D. Scarring alopecia in discoid lupus erythematosus: a clinical, histopathologic and immunopathologic study. Lupus. 2004;13(6):455-62.

17. Fischer $\mathrm{KH}$ and Hyatt AL- The anatomy of the skin and physiology of hair growth. Chapter 14: 175-197. In The Cause and Management of Hirsutism, 1987. Edited by Greenblatt RB, Mahesh VB and Gambrell RD published in the UK by The Parthenon Publishing Group limited Casterton Hall, Carnforth; 
18. Fuchs E, Raghavan S. Getting under the skin of epidermal morphogenesis. Nat Rev Genet. 2002; 3:199-209.

19. Hadshiew IM, Foitzik K, Arck PC, Paus R. Burden of hair loss: stress and the underestimated psychosocial impact of telogen effluvium and androgenetic alopecia. J Invest Dermatol. 2004; 123:455-7.

20. Ham WH- Sistema Tegumentar. Pele e seus Anexos. Histologia - $3^{\circ}$ Edição Brasileira - 1967. Editora Guanabara Koogan S.A - Rio de Janeiro. Pag.571596

21. Hardy M. The secret life of the hair follicle. Trends Genet. 1992; 8:55-61.

22. Headginton JT, Astle N. Familial focal alopecia . Arch Dermatol $1987 ; 123: 234-37$

23. Headington JT. Cicatricial alopecia. Dermatol Clin 1996:14: 773-782.

24. Hollinshead HW. Capítulo 10: A pele e seus anexos. Em Livro-Texto de Anatomia Humana. 1980. Editora Harper \& Row do Brasil L Ltda.; 145-149.

25. Huelsken J, Vogel R, Erdmann B, Cotsarelis G, Birchmeier W. $\beta$-Catenin controls hair follicle morphogenesis and stem cell differentiation in the skin. Cell. 2001; 105:533-45.

26. Irby-Massie, GL. Alopekia: Mangy as a Fox. Em: http://www.camws.org/meeting/2007/program/abstracts/01D2\%20Irby\%20M assie.htm. Acesso em 20 de setembro de 2010.

27. Ito M, Kizawa K, Hamada K, Cotsarelis G. Hair follicle stem cells in the lower bulge form the secondary germ, a biochemically distinct but functionally equivalent progenitor cell population, at the termination of catagen. Differentiation. 2004; 72:548-57. 
28. Jankovic SM e Jankovic SV. O controle do crescimento do cabelo. $\begin{array}{lllll}\text { Dermatology } & \text { Online } & \text { Journal } & \text { 1998; } & 4(1):\end{array}$ .http://huntley.ucdavis.edu/DOLvol4num1/original/ $\quad$ WH- Sistema Tegumentar . Pele e seus Anexos. Histologia - 3º Edição Brasileira - 1967 pags: 571-596. Editora Guanabara Koogan S.A - Rio de Janeiro.

29. Junqueira LC e Carneiro J - Capítulo 18: Pele e Anexos. Histologia Básica 9 Edição 1999- Editora Guanabara Koogan S.A. Rio de Janeiro - RJ.

30. Karnik P, Smith M, Gilliam A, McCormick TS, Cooper KD, Mirmirani P. Hair follicle stem cell-specific PPAR gamma deletion causes scarring alopecia. J Invest Dermatol 2007: 127(Suppl. 1): s110.

31. Kealey T, Philpott M and Guy R. The regulatory biology of the human pilosebaceous unit. Baillieres Clin Obstet Gynaecol. 1997; 11 (2): 205-227.

32. Matzinger P. The danger model: a renewed sense of self. Science 2002: 296: $301-305$.

33. McElwee KJ, Pickett P, Oliver RF. The DEBR rat, alopecia areata and autoantibodies to the hair follicle. Br J Dermatol 1996: 134: 55-63.

34. McElwee KJ. Etiology of cicatricial alopecias: a basic science point of view Dermatologic Therapy. 2008; 21.

35. Montagna W, Parakkal FP. The Structure and Function of the Skin. New York: Academic Press, 1974.

36. Moresi JM, Horn TD. Distribution of Langerhans cells in human hair follicle. J Cutan Pathol 1997: 24: 636-640. 
37. Nakamura M, Tobin D, Richards-Smith B, et al. Mutant laboratory mice with abnormalities in pigmentation: annotated tables. J Deramatol Sci. 2002; 28:133.

38. Olsen EA, Bergfeld WF, Cotsarelis G, et al. Summary of North American Hair Research Society (NAHRS) - sponsored Workshop on Cicatricial Alopecia, Duke University Medical Center, February 10 and 11, 2001. J Am Acad Dermatol. 2003; 48: 103 - 110.

39. Osawa M, Egawa G, Mak SS, et al. Molecular characterization of melanocyte stem cells in their niche. Development. 2005; 132:5589-99.

40. Oshima H, Rochat A, Kedzia C, et al. Morphogenesis and renewal of hair follicles from adult multipotent stem cells. Cell. 2001; 104:233-45.

41. Otberg N, Wen-Yu W, McElwee KJ, Shapiro J. Diagnosis and management of primary cicatricial alopecia: part I. Skinmed. 2008; 1:19-26.

42. Owen, James. Pêlos humanos têm Origem em garras de repteis. Em: http://www.us.terra.com/tecnologia/interna/0,,OI33660614EI8147,00.html.A cesso em:14 maio 2010.

43. Paus R, Handjiski B, Czarnetzki BM, Eichmüller S.A murine model for inducing and manipulating hairfollicle regression (catagen): effects of dexamethasone Paus R, van der Veen C, Eichmüller S, et al. Generation and cyclic remodeling of the hair follicle immune system in mice. J Invest Dermatol. 1998; 111:7-18.

44. Paus R, Peters EM, Eichmüller S, Botchkarev VA. Neural mechanisms of hair growth control. J Investig Dermatol Symp Proc. 1997; 2:61-8. 
45. Paus R, Cotsarelis G. The biology of hair follicles. N Engl J Med. 1999; $341: 491-7$.

46. Paus $\mathrm{R}$, Ito $\mathrm{N}$, Ito $\mathrm{T}$. The hair follicle and immune privilege. $\mathrm{J}$ Investig Dermatol Symp Proc. 2003; 8:188-94.

47. Paus R and Cotsarelis G. The biology of hair follicles. N Engl J Med 1999; 341(7): 491-97.

48. Paus R, Peker S and Sundberg J. Biology of Hair and Nails. In Bolognia JL, Jorizzo JL, Rapini RP. Dermatology (vol. I). Spain: Mosby Elsevier; 2008. p. 965-986.

49. Pereira, José Marcos. Historia da Tricologia. Em: http://jmarcosderm.med.br/blog/2009/07/15/historia-da-tricologia/. Acesso em: 14 maio 2010.

50. Pereira, Flavia Aparecida. Cabelos: Anatomia, Fisiologia, Alteraçoes Geneticas e Adquiridas. Em: http://www.sbcd.org.br/pagina. php?Id=582. Acesso em: 14 maios 2010.

51. Peters E, Tobin D, Botchkareva N, et al. Migration ofmelanoblasts into the developing murine hair follicle is accompanied by transient c-Kit expression. J Histochem Cytochem. 2002; 50:751-66.

52. Pinkus H. Differential patterns of elastic fibers in scarring and non-scarring alopecias. J Cutan Pathol. 1978:5:93.

53. Randall VA, Hibberts NA, Thornton MJ, et al. Do androgens influence hair growth by altering the paracrine factors secreted by dermal papilla cells. Eur J Dermatol. 2001; 11:315-20. 
54. Ristrepo R, Mackee PH and Calonje E. Diseases of the hair- Scarring Alopecias. In Mackee PH, Calonje E, Granter SR (vol. II). China: Mosby Elsevier; 2008. p. 1061-1123.

55. Robbins CR. Chemical and physical behavior of human hair. Springer. 4 ed. 2002.

56. Rosenblum MD, Yancey KB, Olasz EB, Truitt RL. CD200, a“no danger" signal for hair follicles. J Dermatol Sci 2006: 41:165-174.

57. Ross EK, Tan E, Shapiro J. Update on primary cicatricial alopecias. Am J Acad Dermatol 2005 53:1-37.

58. Ross EK. Primary cicatricial alopecia: clinical features and management. Clinical Dermatol Nurs. 2007 Apr;19(2):137-43.

59. Sampaio SAP e Rivitti EA- Anatomia e fisiología da pele. Dermatologia $2^{\circ}$ Edição 2000; 3-35 Editora Artes Médicas LTDA.

60. Schmidt-Ullrich R, Paus R. Molecular principles of hair follicle induction and morphogenesis. Bioessays. 2005;27:247-61.

61. Schmidt-Ullrich R, Aebischer T, Huelsken J, et al. Requirement of NF$\mathrm{kB} / \mathrm{Rel}$ for the development of hair follicles and other epidermal appendices.Development. 2001; 128:3843-53.

62. Sehgal VN, Srivastva G, Bajaj P. Cicatricial (scarring) alopecias. Int J Dermatol 2001 40: 241-248.

63. Sellheyer K and Bergfeld WF. Histopathologic Evaluation of Alopecias. Am J Dermatopathol. 2006; 28:236-59.

64. Sharpe PT. Hair today, teeth and scales yesterday? Curr Biol. 2001; 11: R751-2. 
65. Shitara A, Igareshi R, Morohashi M. Folliculitis decalvans and cellular immunity: two brothers with oral candidiasis. Jpn j Drmatol 1974; 28 : 133 [ in japanese].

66. Sinclair RD, Banfield CC, Dawber RPR. Handbook of Diseases of the Hair and Scalp. Oxford: Blackwell Science, 1999.

67. Somani N, Bergfeld WF. Cicatricial alopecia: classification and histopathology. Dermatologic Therapy. 2008; 21(4) 221 - 237.

68. Sperling LC, Cowper SE. The histopathology of primary cicatricial alopecia. Semin Cutan Med Surg 2006: 25: 41-50.

69. Sperling LC.Scarring. Hair anatomy for the clinician. J Am Acad Dermatol.1991;25:1-17.

70. Sperling LC.Scarring. Alopecia and the dermatopathologist. J Cutan Pathol $.2001 ; 28: 333-342$.

71. Sperling LC. Alopecias. Biology of Hair and Nails. In Bolognia JL, Jorizzo JL, Rapini RP. Dermatology (vol. I). Spain: Mosby Elsevier; 2008. p. 9871005.

72. Stefanato C M. Histopathology of alopecia: a clinicopathological approach to diagnosis Histopathology. 2010; 56 (1): 24-38.

73. Stenn K, Paus R. Controls of hair follicle cycling. Physiol Rev. 2001;81:449_ 94.

74. Sterling JC. Human papillomaviruses and skin cancer. J Clin Virol. 2005; 32 : p.67-71.

75. Sundberg JP, Boggess D, Sundberg BA, et al. Asebia-2J (Scd1(ab2J)): a new allele and a model for scarring alopecia.Am J Pathol 2000: 156: 2067-2075. 
76. Sundberg JP, King LE Jr. Mouse models for the study of human hair loss. Dermatol Clin 1996: 14: 619-632.

77. Sundberg JP, Peters EM, Paus R. Analysis of hair follicles in mutant laboratory mice. J Investig Dermatol Symp Proc. 2005; 10:264-70.

78. Takahashi K, Folmer J, Coulombe PA. Increased expression of keratin 16 causes anomalies in cytoarchitecture and keratinization in transgenic mouse skin. J Cell Biol 1994:127: 505-520. Wickett RR Permanent waving and straightening of hair. Cutis 1987; 39(6): 496-497.

79. Tan E, Martinka M, Ball N, Shapiro J. Primary cicatricial alopecias: clinicopathology of 112 cases. J Am Acad Dermatol. 2004 Jan;50(1):25-32.

80. Taylor G, Lehrer MS, Jensen PJ, et al. Involvement of follicular stem cells in forming not only the follicle butalso the epidermis. Cell 2000; 102:451-61.

81. Templeton SF, Solomon AR. Scarring alopecia: a classification based on microscopic criteria. J Cutan Pathol 1994; 21: 97-109.

82. Thibaut S, Gaillard O, Bouhanna P, Cannell DW, Bernard BA. Human hair shape is programmed fromthe bulb. Br J Dermatol. 2005; 152:632-8.

83. Tobin DJ, Paus R. Graying: gerontobiology of the hair follicle pigmentary unit. Exp Gerontol. 2001; 36:29-54.

84. Tobin DJ. Characterization of hair follicle antigens targeted by the anti-hair follicle immune response. J Investig Dermatol Symp Proc 2003: 8: 176-181.

85. Trachsler S, Trueb RM. Value of direct immunofluorescence for differential diagnosis of cicatricial alopecia. Dermatology 2005: 211: 98-102.

86. Trüeb RM. Hair loss. Praxis (Bern 1994) 2003; 92(36): 1488-1496. 
87. Unger WP. Hair transplantation: current concepts and techniques. J Investig Dermatol Symp Proc. 2005; 10:225-9.

88. van Osch LD, Oranje AP, Keukens FM, van Voorst. Vader PC,Veldman E. Keratosis follicularis spinulosa decalvans: a family study of seven male cases and six female carriers. J Med Genet 1992: 29: 36-40.

89. Whiting D. The Structure of the Human Hair Follicle. Fairfield, NJ: Canfield Publishing, 2004.

90. Whiting DA. Histopathologic features of alopecia areata: a new look. Arch Dermatol 2003: 139: 1555-1559.

91. Wickett RR Permanent waving and straightening of hair. Cutis 1987; 39(6):496-497.

92. Wu P, Hou L, Plikus M, et al. Evo-Devo of amniote integuments and appendages. Int J Dev Biol. 2004; 48:249-70.

93. Yano K, Brown LF, Detmar M. Control of hair follicle growth and size by VEGF-mediated angiogenesis. J Clin Invest. 2001; 107:409-17. 